Nevada

Environmental

Restoration

Project

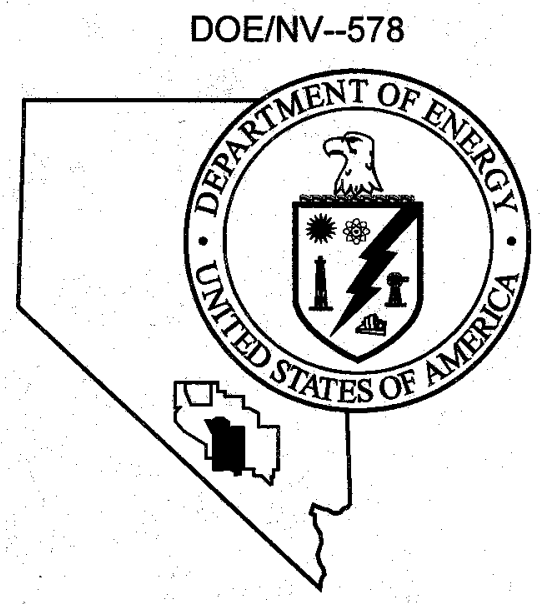

Closure Report for

Corrective Action Unit 109:

U-2bu Subsidence Crater

Nevada Test Site, Nevada

Controlled Copy No::

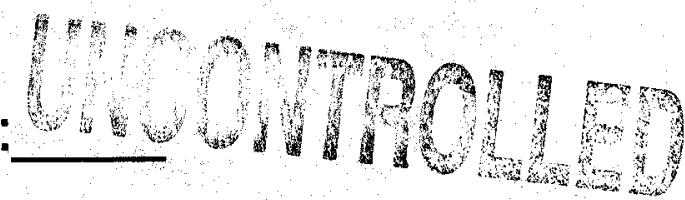

Revision: 0

November 1999

Environmental Restoration

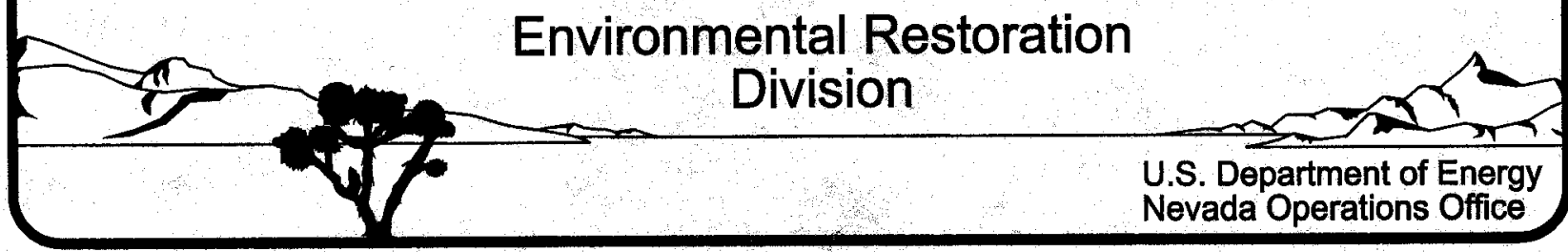


Available to the public from:

U.S. Department of Commerce

National Technical Information Service

5285 Port Royal Road

Springfield, VA 22161-0002

(703) $487-4650$

Available electronically at http://www.doegov/bridge. Available to U.S. Department of Energy and its contractors in paper form:

U.S. Department of Energy

Office of Scientific and Technical Information

P.O. Box 62

Oak Ridge, TN 37831-0062

(423) 576-8401 


\section{ERRATA SHEET}

The third sentence of Section 5.0 and the third sentence of Section 5.1 on page 22 of the Closure Report for Corrective Action Unit 109: U-2bu Subsidence Crater, Nevada Test Site, Nevada, erroneously reference NAC 459.9974 (NAC, 1996b). The correct regulatory reference should be NAC 445A.227 (NAC, 1996a). 


\title{
CLOSURE REPORT FOR CORRECTIVE ACTION UNIT 109: U-2BU SUBSIDENCE CRATER NEVADA TEST SITE, NEVADA
}

\author{
Controlled Copy No.:
}

Revision 0

November 1999

Prepared for the U.S. Department of Energy

Nevada Operations Office under Contract No. DE-AC08-96NV11718 
THIS PAGE INTENTIONALLY LEFT BLANK 
DOE/NV--578

\section{CLOSURE REPORT FOR CORRECTIVE ACTION UNIT 109: U-2BU SUBSIDENCE CRATER NEVADA TEST SITE, NEVADA}

Approved By: Sabine T. Curtis

for Janet L. Appenzeller-Wing, Project Manager Industrial Sites Project

Approved By: $\int_{\text {Runore C. Wycoff, Division Director }} \underbrace{}_{\substack{\text { Environmental Restoration Project }}}$
Date: $11 / 5 / 99$

Date: $11 / 5 / 99$ 
THIS PAGE INTENTIONALLY LEFT BLANK 


\section{TABLE OF CONTENTS}

FIGURES $\ldots \ldots \ldots \ldots \ldots \ldots \ldots \ldots \ldots \ldots \ldots \ldots \ldots \ldots \ldots \ldots \ldots \ldots \ldots$ vii

TABLES $\ldots \ldots \ldots \ldots \ldots \ldots \ldots \ldots \ldots \ldots \ldots \ldots \ldots \ldots \ldots \ldots$ vii

ACRONYMS AND ABBREVIATIONS $\ldots \ldots \ldots \ldots \ldots \ldots \ldots \ldots \ldots \ldots \ldots \ldots \ldots$ vii

EXECUTIVE SUMMARY $\ldots \ldots \ldots \ldots \ldots \ldots \ldots \ldots \ldots \ldots \ldots \ldots \ldots \ldots \ldots$ ix

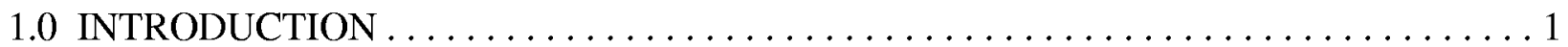

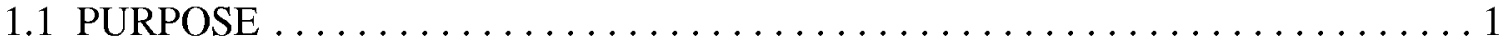

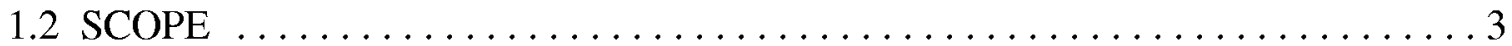

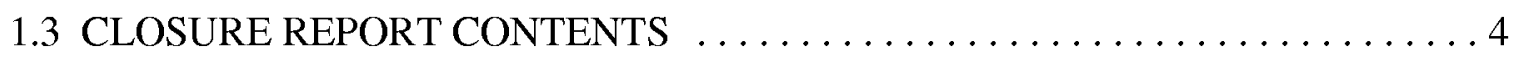

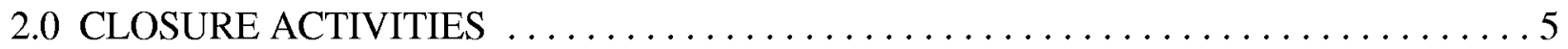

2.1 DESCRIPTION OF CORRECTIVE ACTION ACTIVITIES $\ldots \ldots \ldots \ldots \ldots \ldots$

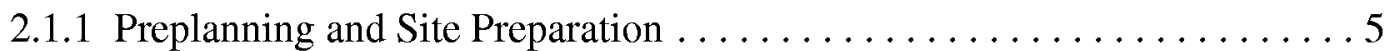

2.1.2 Pre-Excavation Activity Geoprobe ${ }^{\circledR}$ Sampling . . . . . . . . . . . . 5

2.1.3 Removal and Radiological Survey of Metal Debris . . . . . . . . . . 8

2.1 .4 Excavation of the Lead-Impacted Soil . . . . . . . . . . . . . . . 8

2.1.5 Decontamination/Radiological Survey of Equipment . . . . . . . . 9

2.1.6 Construction of Berm . . . . . . . . . . . . . . . . . . . . . 9

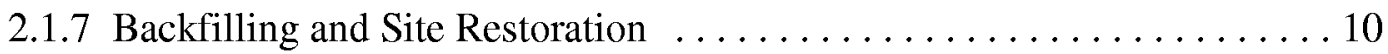

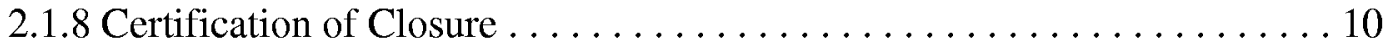

2.2 DEVIATIONS FROM CLOSURE PLAN AS APPROVED $\ldots \ldots \ldots \ldots \ldots \ldots$

2.3 CORRECTIVE ACTION SCHEDULE AS COMPLETED . . . . . . . . . 11

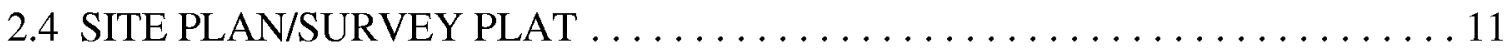

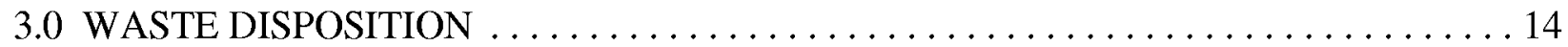

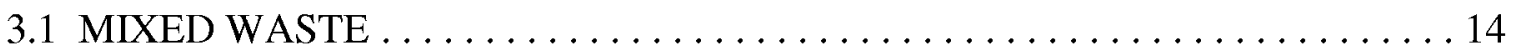

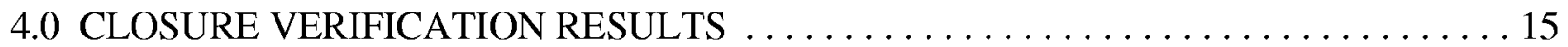

4.1 GEOPROBE $^{\circledR}$ AND BORROW PIT SOIL SAMPLES $\ldots \ldots \ldots \ldots \ldots \ldots \ldots$

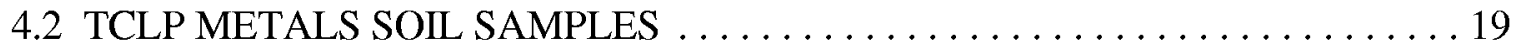

4.3 RADIOLOGICAL SWIPE SAMPLES . . . . . . . . . . . . . . 19

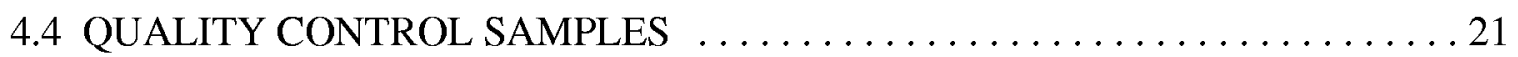

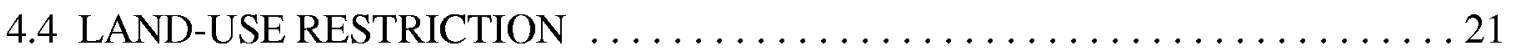




\section{TABLE OF CONTENTS (Continued)}

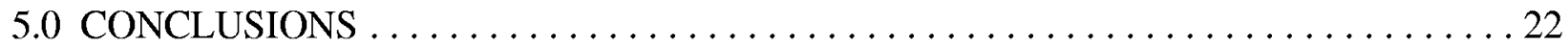

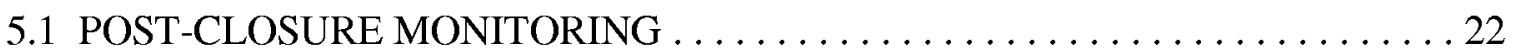

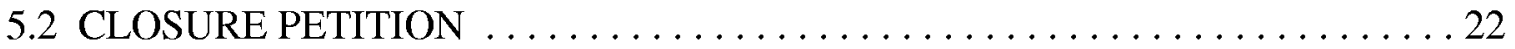

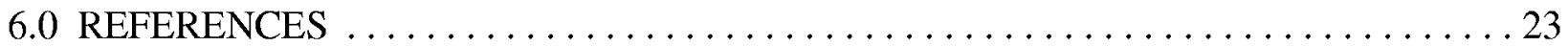

\section{APPENDICES}

Appendix A: Closure Certification

Appendix B: Waste Manifests

Appendix C: Test Results

Appendix D: Photographs of Closure Activities

DISTRIBUTION LIST

\section{FIGURES}

Figure 1 - U-2bu Subsidence Crater Site Location Map . . . . . . . . . . . . . . 2

Figure 2 - U-2bu Subsidence Crater Site Layout for Closure Activities . . . . . . . . . 6

Figure 3 - U-2bu Subsidence Crater Verification Sample Locations . . . . . . . . . . . . 7

Figure 4 - U-2bu Subsidence Crater at Completion $\ldots \ldots \ldots \ldots \ldots \ldots \ldots \ldots \ldots$

\section{TABLES}

Table 1 - U-2bu Subsidence Crater Closure Schedule as Completed 12

Table 2 - Sample Results from Geoprobe ${ }^{\circledR}$ Pre-excavation Activity and Borrow Pit . . . . . 16

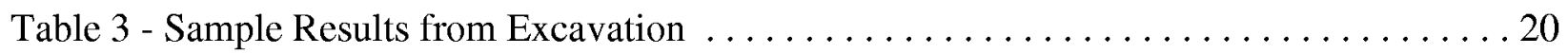




\section{ACRONYMS AND ABBREVIATIONS}

$\mathrm{BN}$

CAU

CFR

DOE

DOE/NV

EPA

FFACO

$\mathrm{ft}$

gal

in

$\mathrm{L}$

$\mathrm{m}$

MDL

$\mathrm{mg} / \mathrm{kg}$

$\mathrm{mg} / \mathrm{L}$

NA

NAC

ND

NDEP

NEPA
Bechtel Nevada

Corrective Action Unit

Code of Federal Regulations

U.S. Department of Energy

U.S. Department of Energy, Nevada Operations Office

Environmental Protection Agency

Federal Facility Agreement and Consent Order

foot

gallon

inch

liter

meter

method detection limit

milligram per kilogram

milligrams per liter

not analyzed

Nevada Administrative Code

not detected

Nevada Division of Environmental Protection

National Environmental Policy Act 


\section{ACRONYMS AND ABBREVIATIONS (Continued)}

NTS

NTSWAC

$\mathrm{pCi} / \mathrm{g}$

POC

SDG

RCRA

REECo

RWAP

TCLP
Nevada Test Site

Nevada Test Site Waste Acceptance Criteria

picocuries per gram

Performance Objective Criteria

sample delivery group

Resource Conservation and Recovery Act

Reynolds Electrical and Engineering Co., Inc.

Radioactive Waste Acceptance Program

Toxicity Characteristic Leachate Procedure 


\section{EXECUTIVE SUMMARY}

The U-2bu subsidence crater is located in Area 2 of the Nevada Test Site. It was created in 1971 by an underground nuclear test named Miniata. The crater has a diameter of 288 meters (944 feet) and an approximate depth of 35 meters ( 115 feet). The $\mathrm{U}-2 \mathrm{bu}$ subsidence crater was used as a land disposal unit for radioactive and hazardous waste from 1973 to 1988. Site disposal history is supported by memorandums, letters, and personnel who worked at the Nevada Test Site at the time of active disposal. Waste disposal into the crater was officially discontinued in March 1989. Based on the results of the analyses reported in the site characterization report, the only area at the U-2bu subsidence crater with lead-impacted soil is located at the crater rim.

Closure activities began on July 26, 1999, with a health and safety kickoff meeting and mobilization of equipment and personnel to the site. A metal pipe and two metal troughs that had been used to dispose of effluent into the crater were removed from the site. A radiological survey indicated that the metal debris was below the established free release criteria and could be disposed in the Area 9 U-10c Landfill. Excavation of lead-impacted soil began on July 27, 1999, and was completed on July 28, 1999. A total of ten B-25 boxes were filled with soil, closed, weighed, and certified by Performance Assurance personnel. These boxes were managed as mixed waste at an on-site 90-day storage area. Verification samples were collected from the excavation and analyzed for leachable metals. No leachable metals were detected above the standard analytical method detection limits. Therefore, the excavation was backfilled with clean borrow soil and the site was regraded. Soil berms were constructed at the southeast and southwest corners of the borrow pit to divert any drainage away from the crater. All chain-link fencing was removed from the site and replaced with the double-strand wire fencing that is standard at subsidence craters at the Nevada Test Site. Closure activities were completed on November 3, 1999, with the shipment and disposal of the waste generated during closure.

The closure was completed following the approved Closure Plan (DOE, 1999a) and certified by a registered, independent Professional Engineer. All mixed waste generated at the site has been disposed in Pit 3 at the Area 5 Radioactive Waste Management Site. All non-hazardous debris has been disposed in the Area 9 U-10c Landfill.

Therefore, the U.S. Department of Energy, Nevada Operations, requests that a Notice of Completion be issued by the Nevada Division of Environmental Protection, and that the U-2bu subsidence crater, Corrective Action Unit 109, be moved from Appendix III to Appendix IV of the Federal Facility Agreement and Consent Order "Closed Corrective Action Units." Because lead-impacted soil has been removed from the site, post-closure monitoring is not required at the site. 
THIS PAGE INTENTIONALLY LEFT BLANK 


\subsection{INTRODUCTION}

This report describes the remediation activities performed and the results of verification sampling conducted at the U-2bu Subsidence Crater. The U-2bu subsidence crater is an historic disposal unit located in Area 2 of the Nevada Test Site (NTS) (Figure 1). The Federal Facility Agreement and Consent Order (FFACO) lists the U-2bu subsidence crater as Corrective Action Unit (CAU) 109 and Corrective Action Site 02-08-01 (FFACO, 1996). Remediation of the U-2bu subsidence crater is required under the Resource Conservation and Recovery Act (RCRA) operational permit, which is the Permit for a Hazardous Waste Facility, Permit Number NEV HW009 (Nevada Division of Environmental Protection [NDEP], 1995), and the FFACO (FFACO, 1996).

\subsection{PURPOSE}

The purpose of this report is to provide documentation of the completed corrective action and provide data supporting the completion of the action. The U-2bu subsidence crater was created in 1971 by an underground nuclear test with the name Miniata. The crater has a diameter of 288 meters (m) (944 feet [ft]) and an approximate depth of $35 \mathrm{~m}(115 \mathrm{ft})$.

The subsidence crater was used as a land disposal unit for radioactive and hazardous waste from 1973 to 1988 . The site disposal history is supported by memorandums, letters, and personnel who worked at the NTS at the time of active disposal. Wastes included radioactive-impacted drilling mud and decontamination waste water. Waste was dumped into the crater from the northern rim. According to a Reynolds Electrical and Engineering Co., Inc. (REECo) memorandum, waste disposal into the crater was officially discontinued in March 1989

(U.S. Department of Energy [DOE], 1999a).

Disposal of waste into the crater resulted in the development of an erosion gully on the northern side of the crater running from the top of the crater to an artificial alluvial fan that formed at the bottom. Historical aerial photographs of the U-2bu subsidence crater show that the fan has grown over the years in association with the disposal of waste.

Previous characterization activities at U-2bu were conducted in April 1998 and involved the collection of surface and subsurface soil sampling from the north crater rim, the crater bottom, sides, gully, and artificial alluvial fan (DOE, 1998a).

Based on the sample results from the site characterization, the only constituents of concern in the U-2bu subsidence crater include toxicity characteristic leaching procedure (TCLP) (leachable) lead and petroleum hydrocarbons (DOE, 1998a). All other potential constituents of concern were below the U.S. Environmental Protection Agency (EPA) Region IX Preliminary Remediation Goals (EPA, 1996a), and the RCRA toxicity characteristics levels established in Title 40 Code of Federal Regulations (CFR) §261.24 (EPA, 1996b). 


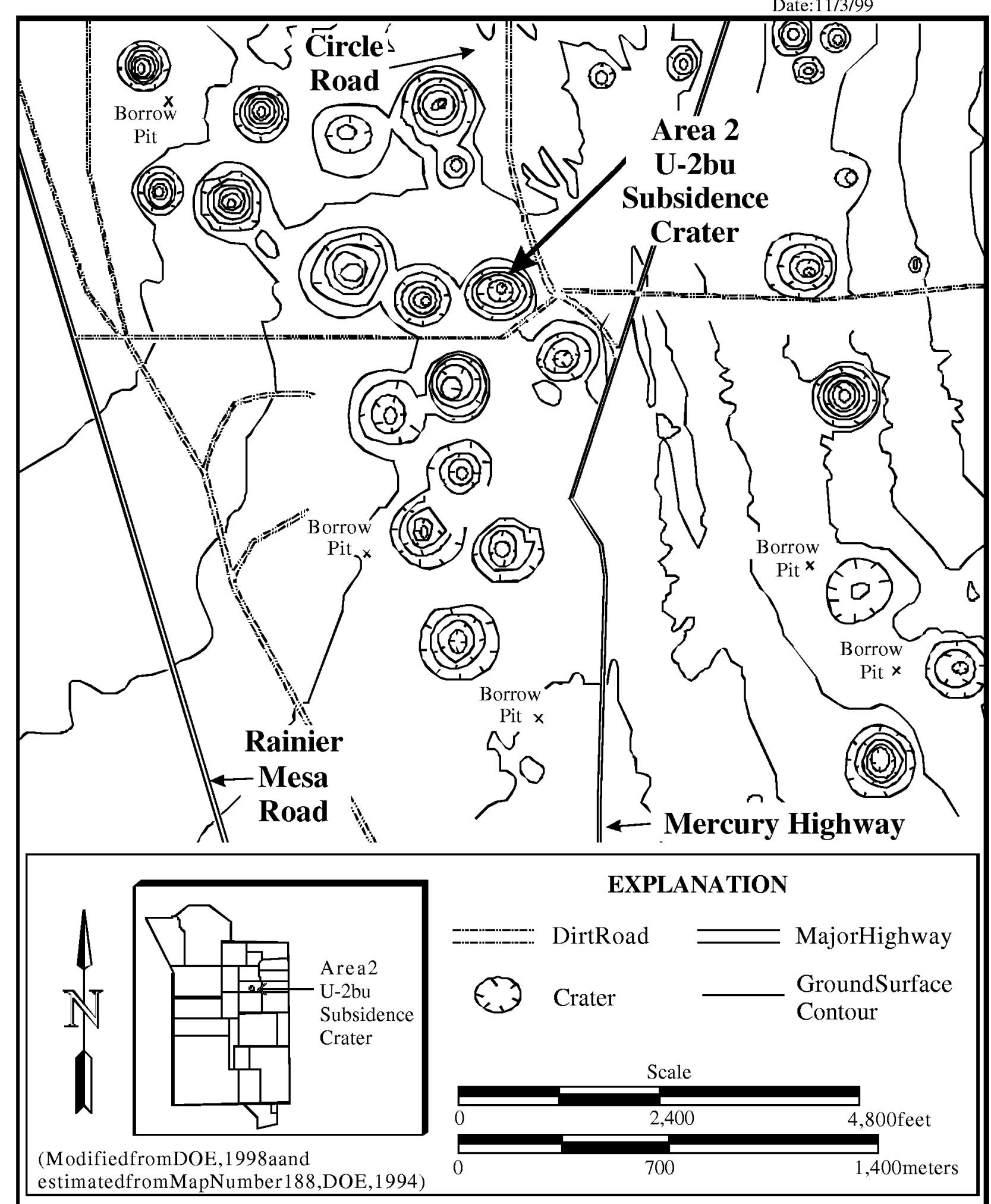

FIGURE 1

U-2BU SUBSIDENCE CRATER SITE LOCATION MAP 
As part of the Data Quality Objective process, and later in the approved Characterization Report (DOE, 1998a), the radiological constituents were not considered constituents of concern at this site. Radiological constituents are only a concern for waste disposal purposes.

Leachable lead was detected at a concentration of 5.7 milligrams per liter $(\mathrm{mg} / \mathrm{L})$ at the top of the crater, just above the erosion gully. This concentration exceeded the Title 40 CFR $\$ 261.24$ (EPA, 1996c) TCLP level of $5.0 \mathrm{mg} / \mathrm{L}$ for lead and, therefore, required removal.

Total petroleum hydrocarbons in the diesel range were found in one sample and its duplicate at the bottom of the crater at a maximum concentration of 190 milligrams per kilogram $(\mathrm{mg} / \mathrm{kg})$. This result exceeds the $100 \mathrm{mg} / \mathrm{kg}$ action level established in the Nevada Administrative Code (NAC) 445A.227 (NAC, 1996a). However, because the unit is located in a remote, arid environment with a deep water table, and the hydrocarbon is present in low levels that are isolated in the bottom of the crater, this portion of the site was administratively closed. Detailed information was provided in Appendix A of the Closure Plan (DOE, 1999a) in the "a through k" assessment of risk (NAC, 1996b) that shows that the level of petroleum hydrocarbons present in the U-2bu subsidence crater does not pose a risk to human health and the environment. This "a through k" assessment of risk was subsequently approved as part of the Closure Plan (DOE, 1999a).

\subsection{SCOPE}

The scope of work for this project consisted of the following activities:

C Preplanning and site preparation, including the preparation of all plans and permits, utility clearance, and mobilization of equipment to the site.

C Pre-excavation Geoprobe ${ }^{\circledR}$ activities.

C Removal and radiological survey of metal debris near the top of the crater.

C Excavation of the lead-impacted soil near the top of the crater.

C Collection of soil samples to verify that lead has been removed to approved levels.

C Radiological survey of excavation equipment.

C Backfilling the excavated areas.

C Construction of a soil berm as a best management practice to prevent preferential run-on into the erosion gully. 
C Removal of the current posting and chain link fencing and restoration of the crater fencing and radiological postings.

C Disposal of excavated materials following applicable federal, state, and DOE regulations following Section 2.3 of the Closure Plan (DOE, 1999a).

C Certification of closure by an independent, Professional Engineer and the U.S. Department of Energy, Nevada Operations Office (DOE/NV) Manager.

Site characterization revealed that the only constituent of concern to be remediated was lead. All lead was removed to below the analytical method detection limit of SW-846, EPA Method 1311/6010 of $0.05 \mathrm{mg} / \mathrm{L}$ (EPA, 1996e), which is below the remediation criteria of $5 \mathrm{mg} / \mathrm{L}$ proposed in the Closure Plan (DOE, 1999a).

\subsection{CLOSURE REPORT CONTENTS}

This document is divided into the following sections as determined in the approved FFACO standardized outline:

$$
\begin{array}{ll}
\text { C } & \text { Section 1.0-Introduction } \\
\text { C } & \text { Section 2.0-Closure Activities } \\
\text { C } & \text { Section 3.0- Waste Disposition } \\
\text { C } & \text { Section 4.0-Closure Verification Results } \\
\text { C } & \text { Section 5.0- Conclusions } \\
\text { C } & \text { Section 6.0-References }
\end{array}
$$

Appendix A: Closure Certification

Appendix B: Waste Manifests

Appendix C: Test Results

Appendix D: Photgraphs of Closure Activities 


\subsection{CLOSURE ACTIVITIES}

\subsection{DESCRIPTION OF CORRECTIVE ACTION ACTIVITIES}

\subsubsection{Preplanning and Site Preparation}

Several plans were prepared prior to beginning corrective action activities at the U-2bu subsidence crater. These plans included the Closure Plan (DOE, 1999a), Field Management Plan (Bechtel Nevada [BN], 1999a), Site-Specific Health and Safety Plan (BN, 1999b) and associated Job Hazard Analysis. In addition, a National Environmental Policy Act (NEPA) checklist was prepared and a site survey was performed by a biologist. The survey confirmed the absence of burrowing owls which are often found in crater areas.

Site preparation involved a utility survey, mobilization of equipment to the site, and designation of the exclusion zone and waste management area.

Above ground utilities are not present on the north side of the U-2bu subsidence crater. A survey of underground utilities was done so that the excavation areas would not cross any utilities lines. A metaldetecting instrument and existing as-built drawings were used for the underground survey. No underground utilities were identified during the survey.

The field office was established in a field van that was stationed to the east of the excavation area. The field van also acted as the portable radiological control station. The exclusion zone was established within the chain link fencing. The gate of the fencing was opened to allow heavy equipment access to the excavation area and yellow rope and radiological control signs were strung across the open gate to designate the exclusion zone. A waste management area was established to the west of the excavation area on level ground and away from heavy equipment traffic. The waste management area was designated with yellow rope. Hazardous waste and radioactive material signs were placed around the rope when waste was placed in the area. The site layout is provided in Figure 2.

\subsubsection{Pre-Excavation Activity Geoprobe ${ }^{\circledR}$ Sampling}

Site characterization indicated that leachable lead was found in one sample at a depth of $1.2 \mathrm{~m}$ (4 ft). In February 1999, soil samples were collected from five locations around the site characterization sample location. Four locations, $1.5 \mathrm{~m}(5 \mathrm{ft})$ on each side of the site characterization sample, and one location directly adjacent to the site characterization sample were investigated. The locations of these samples are provided in Figure 3. The samples were used to more accurately outline the expected boundaries of impacted soil and potentially limit the size of the closure excavation and the subsequent waste soil. Lead was not detected in any of the samples, therefore, these samples served as the excavation boundaries. 


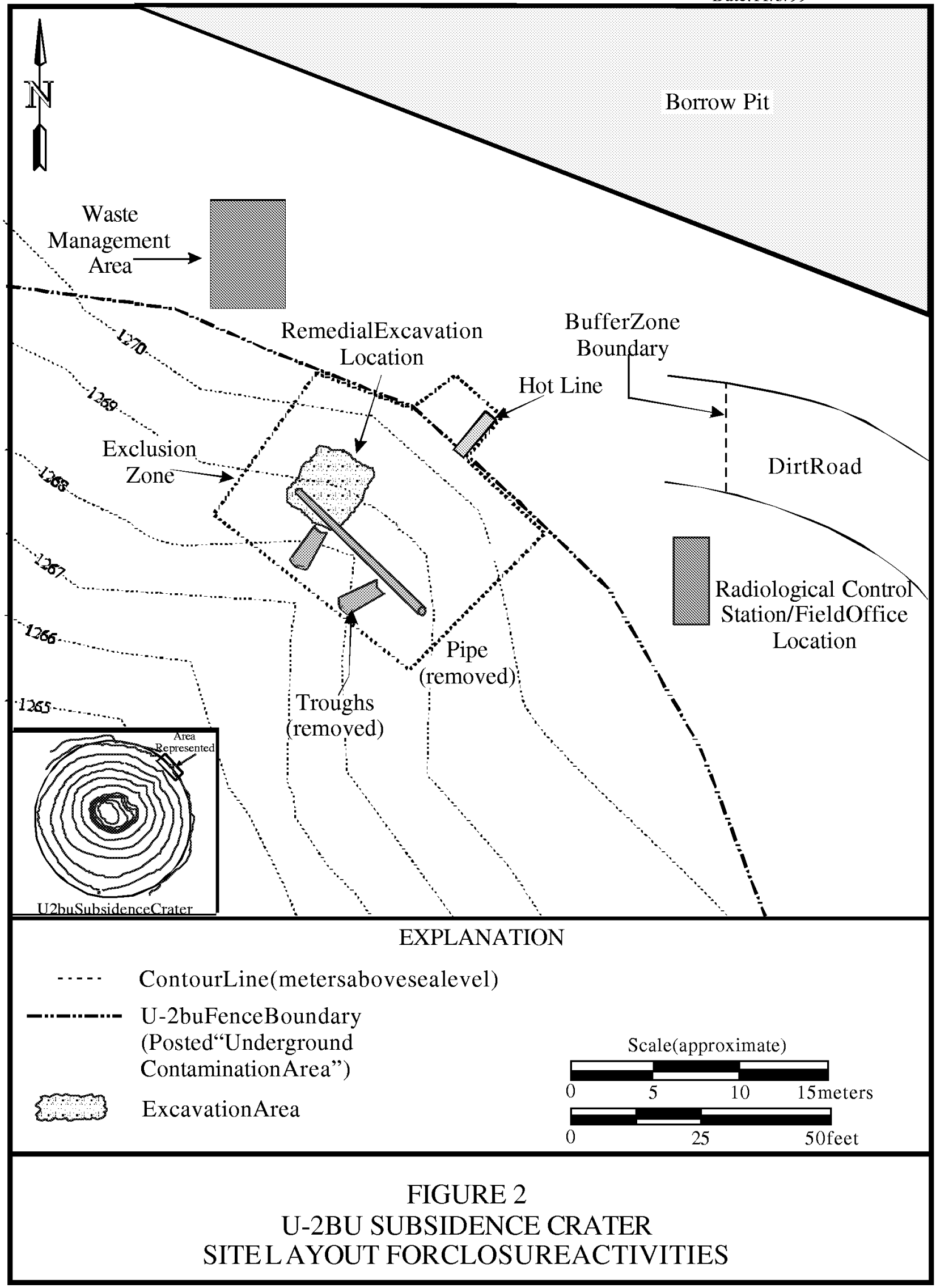




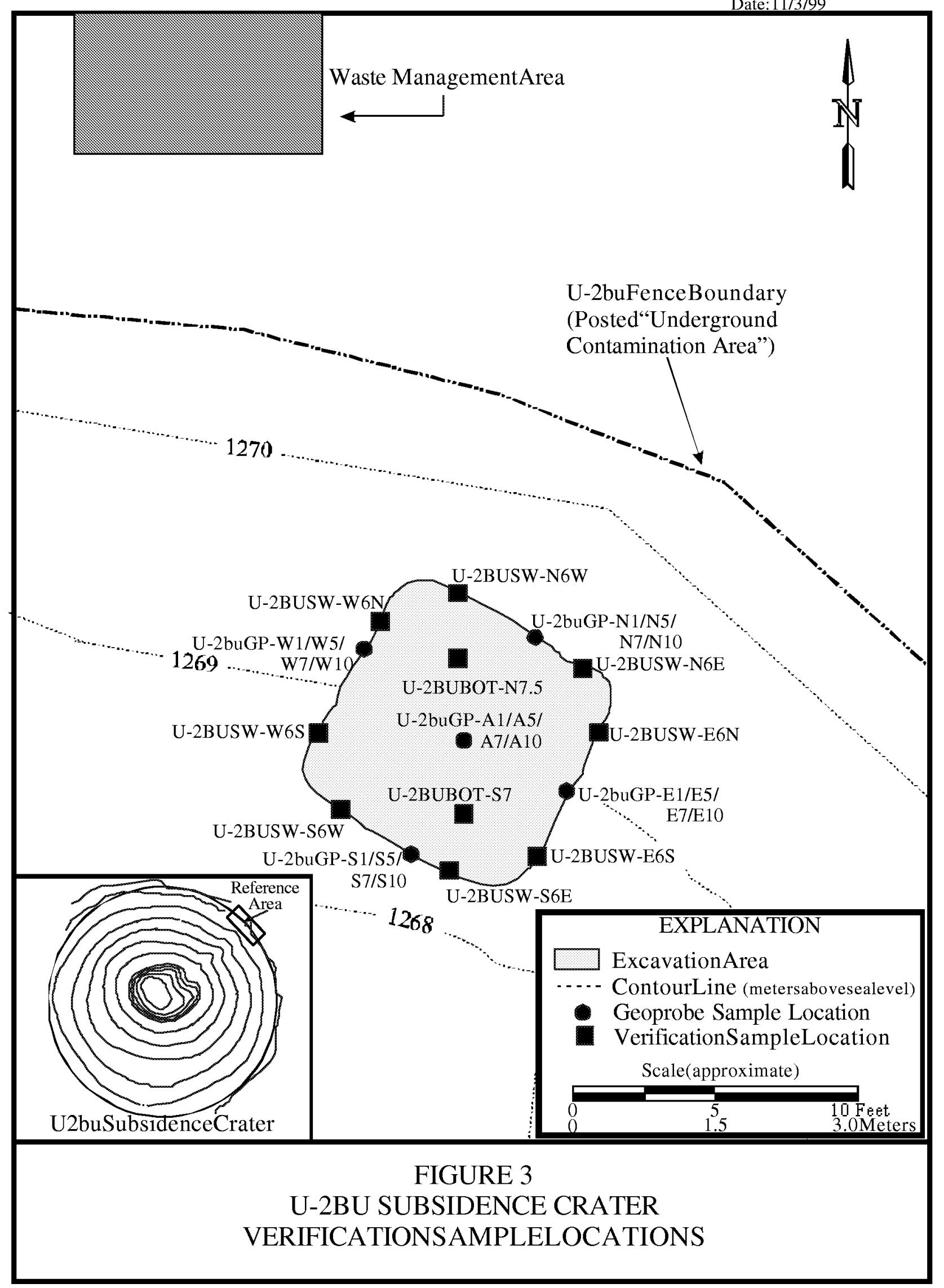


The samples were collected using a Geoprobe ${ }^{\circledR}$ by pushing a $1.2-\mathrm{m}$ (4-ft) by 38 -millimeter (1.5-inch [in]) core barrel to a maximum depth of $3 \mathrm{~m}(10 \mathrm{ft})$ below site grade. Soil samples were collected from the intervals of $0-0.3 \mathrm{~m}, 1.2-1.5 \mathrm{~m}, 1.8-2.1 \mathrm{~m}$, and $2.7-3 \mathrm{~m}(0-1 \mathrm{ft}, 4-5 \mathrm{ft}, 6-7 \mathrm{ft}$, and 9-10 ft). Samples were analyzed using EPA Method, SW-846 1311/6010/7470 for TCLP metals (EPA, 1996e). To determine if the waste would be disposed as mixed waste, soil samples were also analyzed for radiological constituents to ascertain if the levels were above the Performance Objective Criteria (POC) established in the Nevada Test Site Performance Objective for Certification of Nonradioactive Hazardous Waste (REECo, 1995). Although lead was not found in any samples, radiological constituents were detected above the POC, thus, confirming that the waste would be managed as mixed waste. Refer to section 4.1 for details of the sampling activities.

Soil samples were also collected from the borrow pit located adjacent to the U-2bu subsidence crater. Due to the historical use of the land for weapons testing and related activities in this part of the NTS, these samples served to determine if the soil in the borrow pit was appropriate for use as backfill material. These samples were collected using a clean stainless steel scoop from the upper 0-0.15 $\mathrm{m}(0-$ $0.5 \mathrm{ft}$ ) and were only analyzed for radiological constituents. No radiological constituents were detected above background levels in these samples, therefore the borrow pit was the source of all clean backfill and construction soil at the work site.

\subsubsection{Removal and Radiological Survey of Metal Debris}

A metal pipe approximately 10.6-m (35-ft) long and two metal troughs were located at the top of the crater adjacent to the excavation area. This metal debris had been used historically to aid in the channeling of effluent down into the crater during disposal activities. The debris was removed from the excavation area using a backhoe and placed in a Radioactive Material Area until it could be surveyed and swiped for radioactivity. In order to access the interior of the pipe for surveying and swiping, the pipe was cut into eight segments using an acetylene torch. Swipe and survey results determined that the debris was below established release limits and could be managed and disposed as nonradioactive waste. The debris was disposed in the Area 9, U-10c Landfill on the NTS.

\subsubsection{Excavation of the Lead-Impacted Soil}

An area approximately $3 \times 3 \mathrm{~m}(10 \times 10 \mathrm{ft})$ was excavated using a backhoe to a depth of approximately $1.5 \mathrm{~m}(5 \mathrm{ft})$ below ground surface. This excavation was centered around the site characterization sample location that contained the leachable lead. The excavation extended about 0.3 $\mathrm{m}(1 \mathrm{ft})$ deeper than the depth of the detected lead. The soil was placed directly into B-25 boxes for disposal. No visible staining or discoloration was present in the excavation or the excavated soil. 
The excavated soil filled 10 B-25 boxes, which is approximately 27 cubic meters (35 cubic yards) of soil. The boxes were removed from the exclusion zone, surveyed for radiation with hand-held Electras, weighed, labeled, and placed in the waste management area. Filling of the boxes was overseen by Performance Assurance and Radioactive Waste Controls personnel to certify that BN Procedure LE10.308.WWC, "Radioactive Waste Tracking, Handling, and Management at the NTS" (BN, 1998a), the "Nevada Test Site Waste Acceptance Criteria" (NTSWAC) (DOE, 1996), and BN Procedure LE10.302.P, "Radioactive Waste Evaluation," (BN, 1996a) were followed.

\subsubsection{Decontamination/Radiological Survey of Equipment}

All hand-held sampling equipment was decontaminated following ERD-05-701, "Sampling Equipment Decontamination" (DOE, 1998b), prior to being brought to the field. Hand-held sampling equipment was used only once in the field, so that decontamination in the field was not required. After use, the sampling equipment was bagged and brought back to the BN offices in Mercury, NV for decontamination prior to use at another site. Geoprobe ${ }^{\circledR}$ coring equipment was decontaminated between sampling intervals using Alconox ${ }^{\mathrm{TM}}$ and water. The coring equipment was placed in a $208-$ liter (L) (55-gallon [gal]) drum and scrubbed with a brush dipped in the cleaning solution to remove excess soil. Once the coring equipment was cleaned, it was rinsed with deionized water and allowed to air dry. Approximately $11 \mathrm{~L}$ ( $3 \mathrm{gal}$ ) of decontamination rinsate was collected in the drum and managed in an on-site Satellite Accumulation Area. Samples of the rinsate were analyzed and found to contain no detectable levels of radiological constituents. Lead was not analyzed for because no lead was detected in any of the samples. All equipment, including excavation equipment, was surveyed for radiological constituents using hand-held Electras and swipe samples prior to release from the site. All equipment was found to be below the free release limits established in the DOE/YMP Radiological Control Manual (DOE, 1999b).

\subsubsection{Construction of Berm}

Berms originating at the southeast and southwest corners of the borrow pit were constructed as a best management practice to prevent preferential drainage into the northern side of the U-2bu subsidence crater (Figure 4). The berms were constructed in approximately $0.6-\mathrm{m}(2-\mathrm{ft})$ thick lifts of soil from the borrow pit. The lifts were sprayed with water and compacted using the heavy equipment. The east berm is approximately $60-\mathrm{m}(200-\mathrm{ft})$ long and $4.6-\mathrm{m}(15-\mathrm{ft})$ wide. The west berm is approximately 53-m (175-ft) long and 4.6-m (15-ft) wide. Both berms are approximately 1.2-m (4-ft) high in the center and taper at each end to the surrounding natural grade. Both berms also follow the natural curve of the crater to direct water that flows around the borrow pit away from the crater. 


\subsubsection{Backfilling and Site Restoration}

After verification samples indicated that the lead had been removed, the excavation was backfilled with clean fill material. The low areas that were formed by preferential drainage upgradient of the excavation were also backfilled so that the area was mounded above the crater rim grade. All clean fill soil was obtained from the borrow pit adjacent to the crater. All chain-link fencing was removed and replaced with yellow double-strand plastic-coated wire that is standard for use around subsidence craters at the NTS. A demarcation survey was completed subsequent to backfilling the remedial excavation. Upon data evaluation, the "Contamination Area" postings were removed and the site was reposted as an "Underground Contamination Area" consistent with the postings of the crater perimeter.

\subsubsection{Certification of Closure}

As required under Title 40 CFR $\$ 264.115$ (EPA, 1996) and Title 40 CFR $\$ 270.1(\mathrm{c})(5)$ (EPA, 1996d), closure must be certified by an independent Professional Engineer. Dean Nelson of PEER Consultants certified this closure. He reviewed the Closure Plan (DOE, 1999a), all aspects of the closure activities, and the final laboratory data to reach his conclusion that clean closure was accomplished according to the Closure Plan (DOE, 1999a). In addition, the DOE/NV Manager has also certified the closure of CAU 109. The Certifications of Closure are provided in Appendix A.

\subsection{DEVIATIONS FROM CLOSURE PLAN AS APPROVED}

No significant deviations occurred from the approved scope of work as outlined in the Closure Plan (DOE, 1999a). However, the schedule for the start date of closure activities was moved from May to July. This extension had no impact on the closure activities or meeting the FFACO Closure Report deadline of November 30, 1999. Also, the Closure Plan (DOE, 1999a) proposed collecting and analyzing 50 radiological swipe samples from the metal debris. Upon cutting the pipe, additional handheld instrument readings were obtained. Based on the low levels of radioactivity indicated by these instrument readings, the Radiological Control Technicians determined that fewer swipe samples would be required. Therefore, only 35 swipe samples were collected and analyzed for the metal debris. In addition, the one-minute alpha/beta counts indicated that all metal debris was below free release limits. Therefore, it was not necessary to run the swipes for a 20-minute gamma count to further identify radiological isotopes for waste disposal purposes. 


\subsection{CORRECTIVE ACTION SCHEDULE AS COMPLETED}

The corrective action field activities began on July 26, 1999, and were completed on August 5, 1999. Management and weekly inspections of the B-25 boxes was completed from July 27, 1999, until October 26, 1999. The B-25 boxes were disposed on November 3, 1999, following Radioactive Waste Acceptance Program (RWAP) approval. A detailed schedule as completed for the corrective action is provided in Table 1 .

\subsection{SITE PLAN/SURVEY PLAT}

Survey data of impacted locations were provided in the Characterization Report (DOE, 1998a). No additional survey data were required for this closure. Because engineered construction was not required as part of this closure, as-built drawings are not included in this Closure Report. Figure 3 depicts the location of the verification samples collected and Figure 4 shows the condition of the site, including the location of the diversion berms, following closure activities.

This information will be provided to the BN Archive and Records department for documentation purposes. 
TABLE 1 - U-2BU SUBSIDENCE CRATER CLOSURE SCHEDULE AS COMPLETED

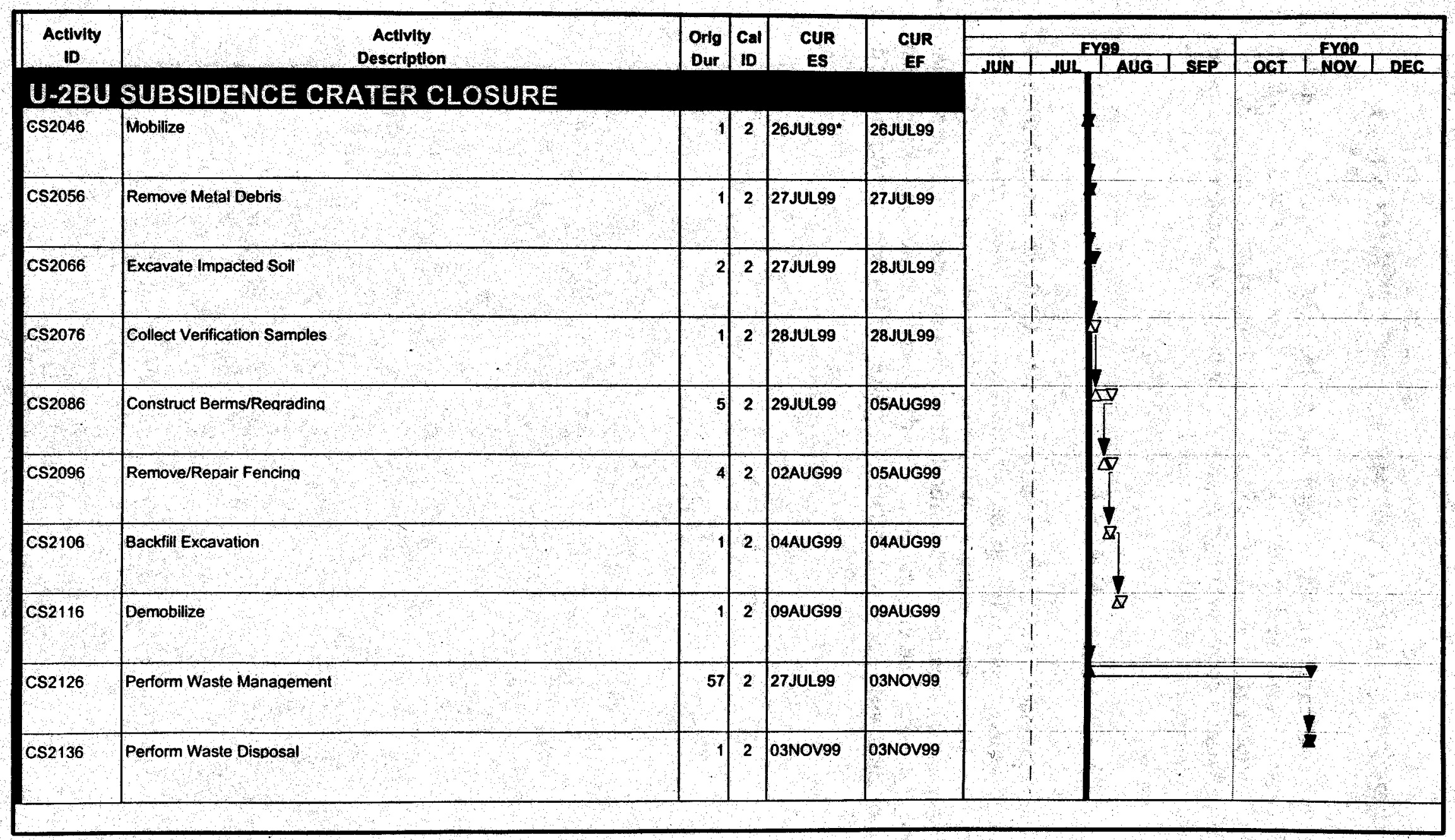

Sheet 1 of 1 


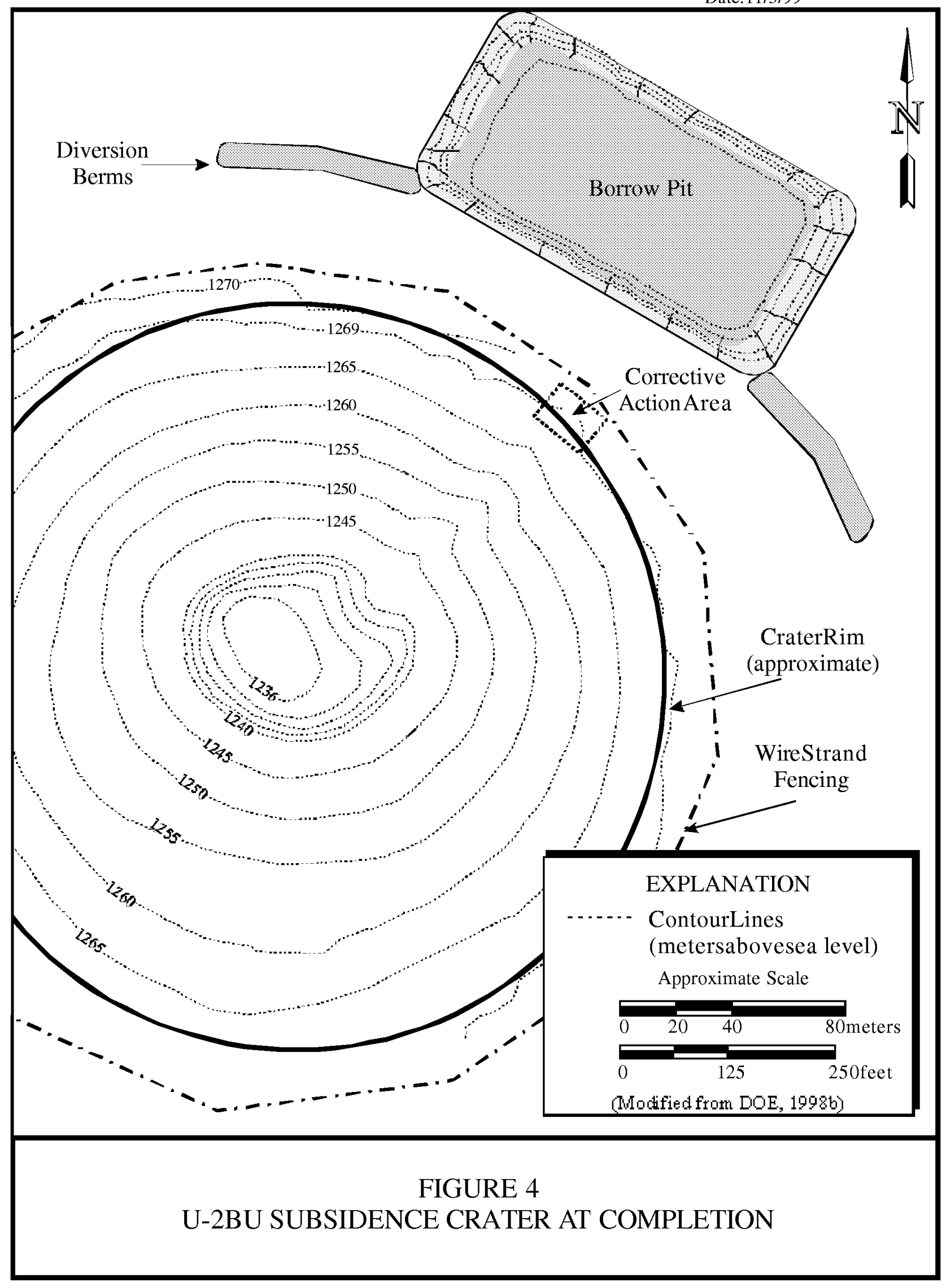




\subsection{WASTE DISPOSITION}

Mixed and non-hazardous wastes were generated as part of the closure activities. Daily sanitary waste, such as cups, bags, and paper, was bagged and placed in a dumpster. The metal pipe segments and troughs were sent to the Area 9, U-10c Landfill on the NTS.

The characterization, handling, shipping, and certification of the impacted soil and other waste were conducted according to the waste profile developed under the requirements of the NTSWAC (DOE, 1996) and the "Bechtel Nevada Waste Certification Program Plan for Radioactive Waste Storage or Disposal" (BN, 1996c) as appropriate. Waste control and certification activities were also subject to a DOE/NV RWAP approval process. Waste manifests for the hazardous and mixed waste shipments are provided in Appendix B.

\subsection{MIXED WASTE}

Mixed waste generation began on July 27 and continued through July 28, 1999. All mixed waste was placed into B-25 boxes under observation by BN Performance Assurance or BN Waste Control personnel. A total of $10 \mathrm{~B}-25$ boxes were filled. The boxes were temporarily closed by securing two of the six clips on the box and weighed using portable scales. Upon approval for disposal, all clips were secured and the boxes were loaded on a flatbed truck for shipment to the NTS Area 5 Radioactive Waste Management Site. The boxes were placed into Pit 3 of the waste management site on November 3, 1999. 


\subsection{CLOSURE VERIFICATION RESULTS}

All verification samples were collected following Section 2.4 of the approved Closure Plan (DOE, 1999a). For the U-2bu subsidence crater, the Site Characterization Report (DOE, 1998a) indicated that leachable lead was the only RCRA constituent of concern above remediation standards and that, although present, radioactive constituents were not a constituent of concern at this site. Therefore, the verification samples were only analyzed for TCLP metals. The TCLP metals analysis was performed using SW-846, EPA Method 1311/6010/7470 by Nevada Environmental Laboratory, located in Las Vegas, Nevada. The laboratory data package is provided in Appendix C.

In addition to soil samples, swipe samples were collected from the metal pipes and troughs. These swipe samples were collected in accordance with BN Procedure L-A14.107.H, Revision 1 (BN, 1998b). The swipes were analyzed using the Single Channel Analyzer for a 1-minute alpha/beta count.

\subsection{GEOPROBE ${ }^{\circledast}$ AND BORROW PIT SOIL SAMPLES}

A total of 22 soil samples, including 2 duplicate samples, were collected using a Geoprobe ${ }^{\circledR}$ by pushing a 1.2-m (4-ft) by 38-mm (1.5-in) core barrel to a maximum depth of $3 \mathrm{~m}(10 \mathrm{ft})$ below site grade. Soil samples were collected from the intervals of $0-0.3 \mathrm{~m}, 1.2-1.5 \mathrm{~m}, 1.8-2.1 \mathrm{~m}$, and $2.7-3 \mathrm{~m}(0-1 \mathrm{ft}, 4-5$ $\mathrm{ft}, 6-7 \mathrm{ft}$, and 9-10 ft). Samples were collected using a clean stainless steel scoop and placed in a 500$\mathrm{ml}$ Nalgene ${ }^{(\mathbb{B}}$ bottle. Samples were analyzed using EPA Method, SW-846 1311/6010/7470 for TCLP metals (EPA, 1996e) and a 20-minute gamma scan using BN analytical procedure L-E10.602.PC (BN, 1996b). Because of the limited soil recovery associated with Geoprobe ${ }^{\circledR}$ samples, both the TCLP metals and radiological analysis were run from the same 500-ml sample volume. No leachable metals were detected in any of the Geoprobe ${ }^{\circledR}$ samples, however, radiological constituents were confirmed to be present in the soils.

Three soil samples were also collected from the borrow pit located adjacent to the U-2bu subsidence crater. These samples were collected using a stainless steel scoop from the upper 0-0.15 m (0-0.5 ft) and were only analyzed for a 20-minute gamma scan using BN analytical procedure L-E10.602.PC (BN, 1996b). No radiological constituents were detected in the borrow pit samples above background levels as defined in the Offsite Radiation Exposure Review Project, Phase II Soils Programs (DOE, 1989). Results for the Geoprobe ${ }^{\circledR}$ and borrow pit samples are provided in Table 2. 

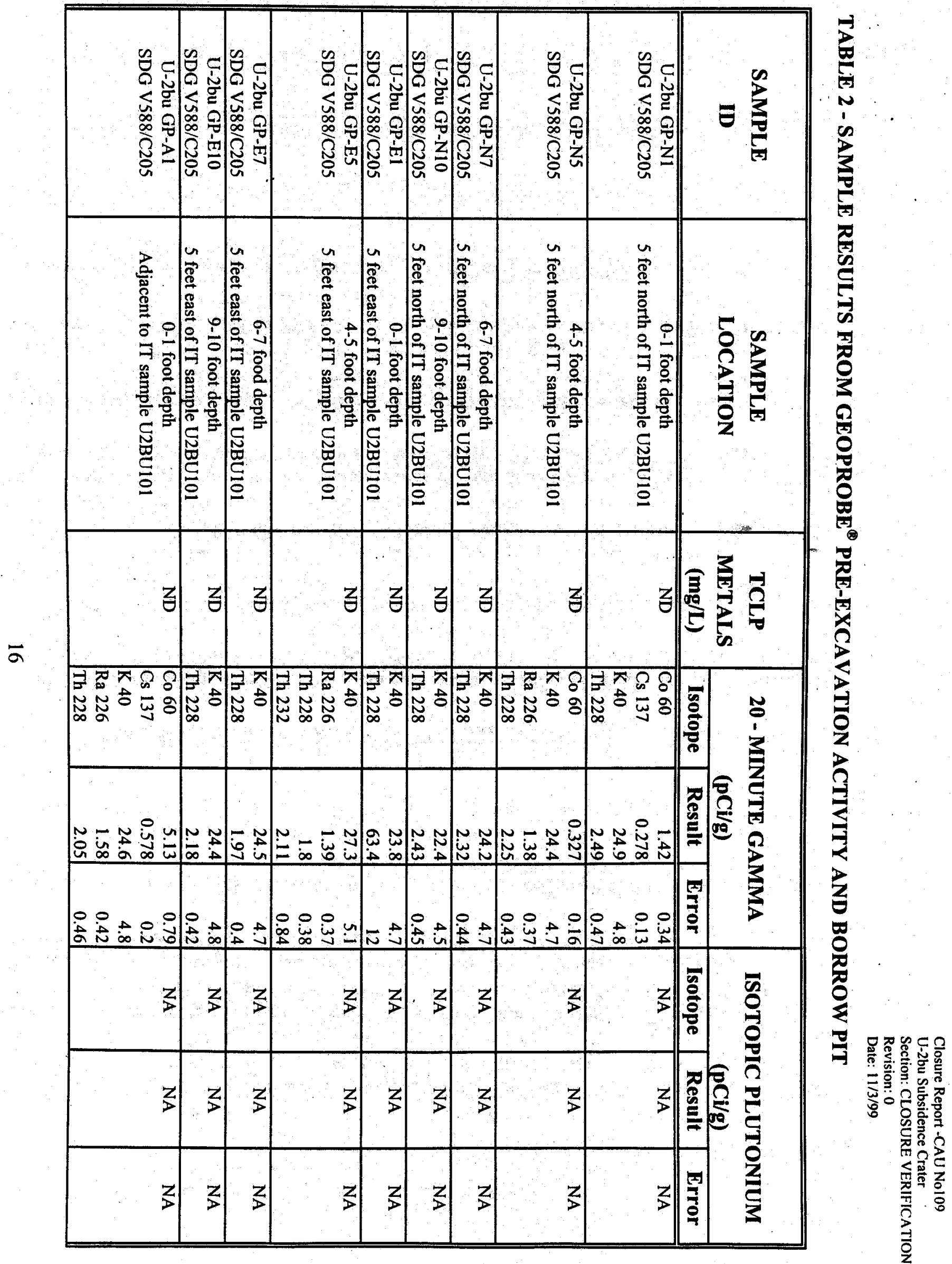
TABLE 2 (Continued)- SAMPLE RESULTS FROM GEOPROBE ${ }^{\circledR}$ PRE-EXCAVATION ACTIVITY AND BORROW PIT

\begin{tabular}{|c|c|c|c|c|c|c|c|c|}
\hline \multirow[t]{2}{*}{$\begin{array}{l}\text { SAMPLE } \\
\text { ID }\end{array}$} & \multirow[t]{2}{*}{$\begin{array}{c}\text { SAMPLE } \\
\text { LOCATION }\end{array}$} & \multirow{2}{*}{$\begin{array}{c}\text { TCLP } \\
\text { METALS } \\
\text { (mg/L) }\end{array}$} & \multicolumn{3}{|c|}{$\begin{array}{c}20 \text { - MINUTE GAMMA } \\
(\mathrm{pCi} / \mathrm{g})\end{array}$} & \multicolumn{3}{|c|}{$\begin{array}{l}\text { ISOTOPIC PLUTONIUM } \\
(\mathrm{pCi} / \mathrm{g})\end{array}$} \\
\hline & & & Isotope & Result & Error & Isotope & Result & Error \\
\hline $\begin{array}{l}\text { U-2bu GP-A3 } \\
\text { SDG V588/C205 }\end{array}$ & $\begin{array}{l}\text { duplicate of sample } \\
\text { U-2bu GP-E10 }\end{array}$ & ND & $\begin{array}{l}\text { Co } 60 \\
\text { K } 40 \\
\text { Th } 228\end{array}$ & \begin{tabular}{l|}
1.13 \\
26.6 \\
2.34
\end{tabular} & $\begin{array}{r}0.3 \\
5 \\
0.46 \\
\end{array}$ & NA & NA & NA \\
\hline $\begin{array}{l}\text { U-2bu GP-A5 } \\
\text { SDG V } 588 / C 205\end{array}$ & $\begin{array}{l}\text { 4-5 foot depth } \\
\text { Adjacent to IT sample U2BU101 }\end{array}$ & ND & $\begin{array}{l}\mathrm{K} 40 \\
\operatorname{Ra} 228 \\
\mathrm{Th} 228\end{array}$ & $\begin{array}{l}26.2 \\
1.41 \\
2.18\end{array}$ & $\begin{array}{r}5 \\
0.37 \\
0.42 \\
\end{array}$ & NA & $\overline{N A}$ & $\overline{\mathrm{NA}}$ \\
\hline $\begin{array}{l}\text { U-2bu GP-A7 } \\
\text { SDG V588/C205 }\end{array}$ & $\begin{array}{l}\text { 6-7 food depth } \\
\text { Adjacent to IT sample U2BU101 }\end{array}$ & ND & \begin{tabular}{|l|}
$\mathrm{K} 40$ \\
$\mathrm{Ra} 226$ \\
Th 228 \\
\end{tabular} & $\begin{array}{r}23.8 \\
1.53 \\
2.0 \\
\end{array}$ & $\begin{array}{l}4.7 \\
0.4 \\
0.4\end{array}$ & NA & NA & NA \\
\hline $\begin{array}{l}\text { U-2bu GP-A10 } \\
\text { SDG V588/C205 }\end{array}$ & $\begin{array}{l}\text { 9-10 foot depth } \\
\text { Adjacent to IT sample U2BU101 }\end{array}$ & ND & $\begin{array}{l}\text { K } 40 \\
\text { Th } 228 \\
\end{array}$ & $\begin{array}{r}22 \\
2.62 \\
\end{array}$ & $\begin{array}{r}4.4 \\
0.47 \\
\end{array}$ & NA & $\mathrm{NA}$ & NA \\
\hline $\begin{array}{l}\text { U-2bu GP-W1 } \\
\text { SDG V } 588 / C 205\end{array}$ & $\begin{array}{c}\text { 0-1 foot depth } \\
5 \text { feet west of IT sample U2BU101 }\end{array}$ & ND & \begin{tabular}{|l|} 
K 40 \\
Th 228 \\
Th 232 \\
\end{tabular} & $\begin{array}{l}26.5 \\
2.57 \\
1.73\end{array}$ & $\begin{array}{r}5 \\
0.46 \\
0.6\end{array}$ & NA & $\mathrm{NA}$ & $\mathrm{NA}$ \\
\hline $\begin{array}{l}\text { U-2bu GP-W5 } \\
\text { SDG V } 588 / C 205\end{array}$ & $\begin{array}{l}\text { 4-5 foot depth } \\
5 \text { feet west of IT sample U2BU101 }\end{array}$ & ND & \begin{tabular}{|l|} 
K 40 \\
$\operatorname{Ra} 226$ \\
Th 228 \\
\end{tabular} & $\begin{array}{l}25.1 \\
1.47 \\
1.82 \\
\end{array}$ & $\begin{array}{r}4.9 \\
0.37 \\
0.39 \\
\end{array}$ & NA & NA & $\overline{\mathrm{NA}}$ \\
\hline $\begin{array}{l}\text { U-2bu GP-W7 } \\
\text { SDG V588/C205 }\end{array}$ & $\begin{array}{l}\text { 6-7 food depth } \\
5 \text { feet west of IT sample U2BU101 }\end{array}$ & ND & $\begin{array}{l}\mathrm{K} 40 \\
\text { Th } 228\end{array}$ & $\begin{array}{l}24.1 \\
1.96 \\
\end{array}$ & $\begin{array}{l}4.7 \\
0.4\end{array}$ & $\mathrm{NA}$ & $\overline{\mathrm{NA}}$ & NA \\
\hline $\begin{array}{l}\text { U-2bu GP-W10 } \\
\text { SDG V } 588 / C 205\end{array}$ & $\begin{array}{c}9-10 \text { foot depth } \\
5 \text { feet west of IT sample U2BU101 }\end{array}$ & ND & \begin{tabular}{|l|} 
K 40 \\
Th 228 \\
\end{tabular} & $\begin{array}{r}23.9 \\
2.4 \\
\end{array}$ & $\begin{array}{r}4.7 \\
0.45 \\
\end{array}$ & NA & NA & NA \\
\hline $\begin{array}{c}\text { U-2bu GP-S1 } \\
\text { SDG V } 588 / C 205\end{array}$ & $\begin{array}{l}0-1 \text { foot depth } \\
5 \text { feet south of IT sample U2BU101 }\end{array}$ & ND & \begin{tabular}{|l|} 
Am 241 \\
Co 60 \\
Cs 137 \\
K 40 \\
$\operatorname{Ra} 226$ \\
Th 228
\end{tabular} & $\begin{array}{r}1 \\
3.68 \\
0.899 \\
25.7 \\
1.75 \\
2.21 \\
\end{array}$ & \begin{tabular}{r|}
0.58 \\
0.61 \\
0.23 \\
4.9 \\
0.45 \\
0.45 \\
\end{tabular} & $\begin{array}{l}\text { Pu238 } \\
\text { Pu } 239\end{array}$ & $\begin{array}{l}0.036 \\
0.865\end{array}$ & $\begin{array}{r}0.064 \\
0.29\end{array}$ \\
\hline
\end{tabular}




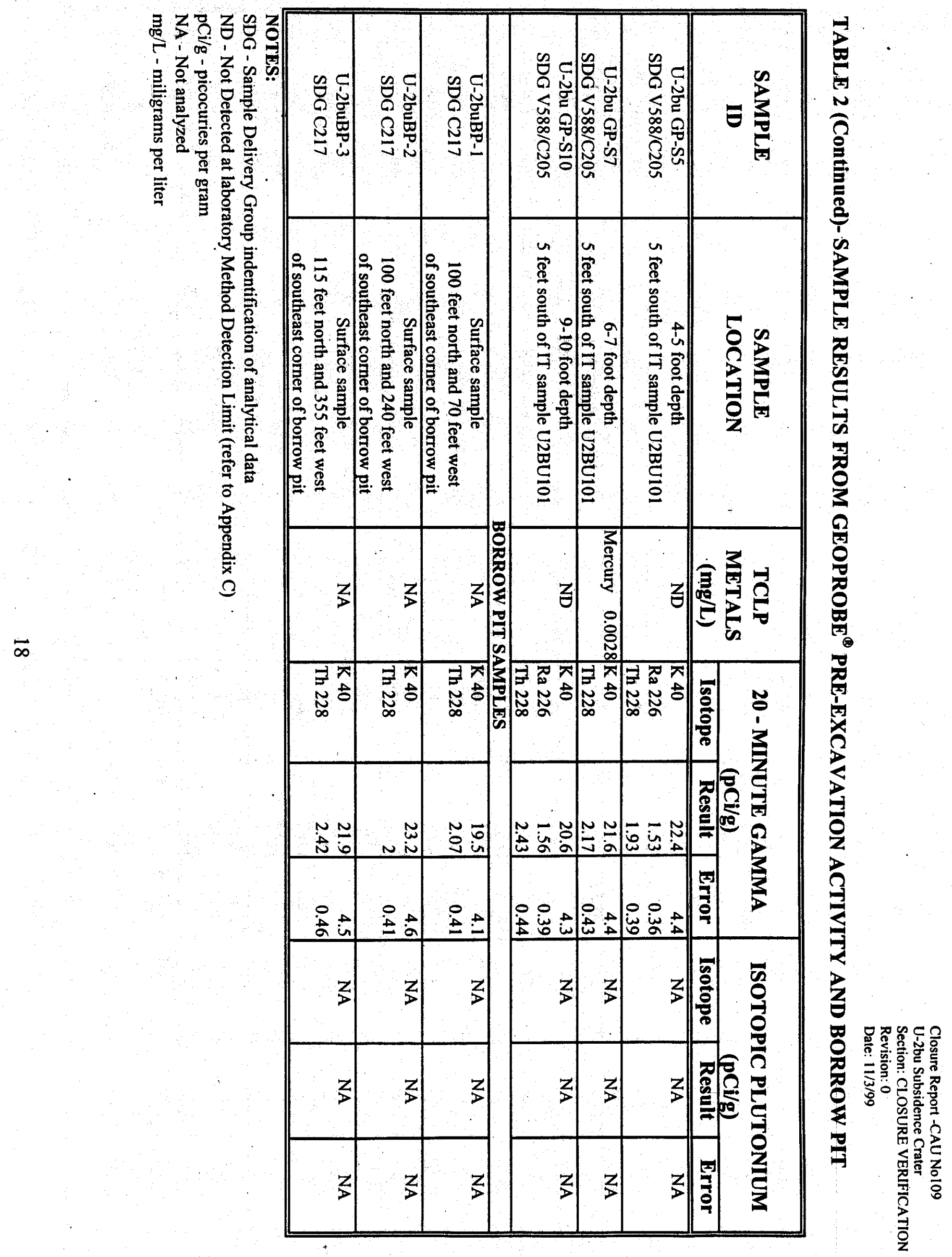




\subsection{TCLP METALS SOIL SAMPLES}

A total of ten verification soil samples and one duplicate sample were collected and analyzed using EPA Method, SW-846 1311/6010/7470 for TCLP metals (EPA, 1996e). Samples were collected from all four sidewalls and the excavation floor every $1.5 \mathrm{~m}(5 \mathrm{ft})$. Sample locations are provided in Figure 3. Both sidewall and bottom samples were collected from below the depth of detectable leachable lead. Because the excavation was deeper than $1.2 \mathrm{~m}(4 \mathrm{ft})$, no one was allowed into the excavation. Therefore, the excavation equipment scraped the wall or floor, as directed by the sampling technician, and the samples were collected as grab samples from the bucket of the excavation equipment. Samples were collected using a clean stainless steel scoop and placed in a 250-milliliter glass jar. All samples were labeled with a unique sample number, placed on ice in a cooler, and handled under chain-ofcustody procedures.

Samples were numbered using the following nomenclature:

\section{U2BUSW-N5E}

Where:

C U2BU is the site location.

C SW is a sidewall sample (BOT was used for excavation floor samples).

$\mathrm{C} \quad \mathrm{N}$ is the compass direction of the sidewall (or relative position of excavation floor samples).

C $\quad 5$ is the depth of sample in feet.

C E is the relative position of the sidewall sample if more than one sample is collected from the same depth but a different location on the same sidewall.

Sample results are provided in Table 3. Sample results indicated that detectable TCLP metal constituents are not present in the soil.

\subsection{RADIOLOGICAL SWIPE SAMPLES}

A total of 35 swipe samples was collected from the interior and exterior of the metal pipe and troughs. In order to access the interior of the metal pipe, it was cut into eight segments. The swipe samples were each run for 1-minute alpha/beta counts in the Single Channel Analyzer. The counts indicated that the metal debris is below the free release criteria. 
TABLE 3 - SAMPLE RESULTS FROM EXCAVATION

\begin{tabular}{|c|c|c|}
\hline $\begin{array}{l}\text { SAMPLE } \\
\text { ID }\end{array}$ & $\begin{array}{c}\text { SAMPLE } \\
\text { LOCATION }\end{array}$ & $\begin{array}{c}\text { TCLP } \\
\text { METALS } \\
(\mathrm{mg} / \mathrm{L})\end{array}$ \\
\hline $\begin{array}{l}\text { U2BUBOT-N7.5 } \\
\text { SDG V665 }\end{array}$ & $\begin{array}{l}7.5 \text { foot depth } \\
\text { North end of excavation bottom }\end{array}$ & $\mathrm{ND}$ \\
\hline $\begin{array}{c}\text { U2BUBOT-W7.5 } \\
\text { SDG V665 }\end{array}$ & Duplicate of U2BUBOT-N7.5 & $\mathrm{ND}$ \\
\hline $\begin{array}{l}\text { U2BUBOT-S7 } \\
\text { SDG V665 }\end{array}$ & $\begin{array}{l}7 \text { foot depth } \\
\text { South end of excavation bottom }\end{array}$ & $\mathrm{ND}$ \\
\hline $\begin{array}{l}\text { U2BUSW-N6E } \\
\text { SDG V665 } \\
\end{array}$ & $\begin{array}{l}6 \text { foot depth } \\
\text { East sample from north sidewall }\end{array}$ & ND \\
\hline $\begin{array}{l}\text { U2BUSW-N6W } \\
\text { SDG V665 }\end{array}$ & $\begin{array}{l}6 \text { foot depth } \\
\text { West sample from north sidewall }\end{array}$ & $\overline{\mathrm{ND}}$ \\
\hline $\begin{array}{l}\text { U2BUSW-S6E } \\
\text { SDG V665 }\end{array}$ & $\begin{array}{l}6 \text { foot depth } \\
\text { East sample from south sidewall } \\
\end{array}$ & $\mathrm{ND}$ \\
\hline $\begin{array}{l}\text { U2BUSW-S6W } \\
\text { SDG V665 }\end{array}$ & $\begin{array}{l}6 \text { foot depth } \\
\text { West sample from south sidewall }\end{array}$ & ND \\
\hline $\begin{array}{l}\text { U2BUSW-E6N } \\
\text { SDG V665 }\end{array}$ & $\begin{array}{l}6 \text { foot depth } \\
\text { North sample from east sidewall }\end{array}$ & $\mathrm{ND}$ \\
\hline $\begin{array}{l}\text { U2BUSW-E6S } \\
\text { SDG V665 }\end{array}$ & $\begin{array}{l}6 \text { foot depth } \\
\text { South sample from east sidewall }\end{array}$ & $\overline{N D}$ \\
\hline $\begin{array}{l}\text { U2BUSW-W6N } \\
\text { SDG V665 }\end{array}$ & $\begin{array}{l}6 \text { foot depth } \\
\text { North sample from west sidewall }\end{array}$ & ND \\
\hline $\begin{array}{c}\text { U2BUSW-W6S } \\
\text { SDG V665 }\end{array}$ & $\begin{array}{l}6 \text { foot depth } \\
\text { South sample from west sidewall }\end{array}$ & $\overline{\mathrm{ND}}$ \\
\hline $\begin{array}{l}\text { U2BU-72899EB } \\
\text { SDG V665 }\end{array}$ & Equipment blank & Mercury 0.014 \\
\hline \multicolumn{3}{|c|}{$\begin{array}{l}\text { NOTES: } \\
\text { SDG - Sample Delivery Group indentification of analytical data } \\
\text { ND - Not Detected at laboratory Method Detection Limit (refer to Appendix C) } \\
\text { mg/L - miligrams per liter } \\
\text { NA - Not analyzed }\end{array}$} \\
\hline
\end{tabular}




\subsection{QUALITY CONTROL SAMPLES}

Blind duplicates collected during the sampling activities, represented at least 20 percent of the samples collected during that sampling event. Analytical results from the blind duplicates were similar to the results from the primary sample.

Equipment blanks were also collected as part of both the Geoprobe ${ }^{\circledR}$ and verification sampling events. The equipment blank for the Geoprobe ${ }^{\circledR}$ samples was nondetect for both TCLP metals and radiological constituents. The equipment blank for the verification samples indicated mercury was present at 0.014 $\mathrm{mg} / \mathrm{L}$. Because no decontamination of equipment took place in the field, the mercury was probably a result of the decontamination procedure that took place prior to the sampling equipment being brought to the field or the distilled water that was used to collect the equipment blank. No mercury was detected in the verification samples, therefore any contamination of that may have been present on sampling equipment had no impact on the verification sample results. Results for the duplicate samples and equipment blanks are reported in the same table as the associated primary samples.

\subsection{LAND-USE RESTRICTION}

Following excavation of the lead impacted soil, all hazardous constituents of concern are below detection levels. In addition, the "a through k" assessment of risk that was approved in the Closure Plan (DOE, 1999a) provides support that conditions at the CAU will not adversely impact human health and the environment. Therefore, post-closure care is not required. The only land restrictions are limited to safety restrictions and postings required for all subsidence craters at the NTS. 


\subsection{CONCLUSIONS}

The information presented in this report documents that the closure of the U-2bu Subsidence Crater was accomplished in accordance with the approved Closure Plan (DOE, 1999a) as a Clean Closure under Section V.A.1 of the RCRA Operational Permit (NDEP, 1995). Under the conditions of 40 CFR \$270.1(c)(5) and (6) (EPA, 1996d), this Closure Report demonstrates that the closure meets or exceeds the requirements of 40 CFR $\$ 264.280(\mathrm{e})$ (EPA, 1996c). In addition, the approved "a through k" analysis for the petroleum hydrocarbon levels in the bottom of the crater (DOE, 1999a), meets the requirements of NAC 459.9974 (NAC, 1996b). Verification sample data demonstrate that all constituents of concern were removed to approved clean-up levels. Appendix A-Closure Certification, contains the certifications from the Independent Professional Engineer and the DOE/NV Manager that the closure meets the requirements identified in these documents.

\subsection{POST-CLOSURE MONITORING}

Site closure was completed by removal of the lead-impacted soil identified during site characterization. Waste was disposed of in accordance with all applicable federal, state, and DOE regulations. Therefore, under the conditions of 40 CFR \$270.1(c)(5) and (6)(EPA, 1996d), and NAC 459.9974 (NAC, 1996b), no post-closure monitoring is required at the U-2bu Subsidence Crater.

\subsection{CLOSURE PETITION}

The closure was completed following the approved Closure Plan (DOE, 1999a) as a Clean Closure under Section V.A.1 of the RCRA Operational Permit (NDEP, 1995). Under the conditions of 40 CFR \$270.1(c)(5) and (6) (EPA, 1996d) for a closure by removal equivalency, this Closure Report demonstrates that the closure meets or exceeds the requirements of $40 \mathrm{CFR} \$ 264.280(\mathrm{e})$ (EPA, 1996c). Lead-impacted soils have been removed from the site and verification samples provide lateral and vertical confirmation of the removal. All mixed waste generated at the site has been disposed in Pit 3 at the NTS Area 5 Radioactive Waste Management Site. All non-hazardous debris has been disposed of in the Area $9 \mathrm{U}-10 \mathrm{c}$ Landfill. Therefore, the DOE/NV requests that a Notice of Completion be issued by the NDEP and that the U-2bu Subsidence Crater, CAU 109, be moved from Appendix III to Appendix IV of the FFACO "Closed Corrective Action Units." 


\subsection{REFERENCES}

BN, see Bechtel Nevada.

Bechtel Nevada, 1996a, "Radioactive Waste Evaluation,” L-E10.302.P, Las Vegas, NV.

Bechtel Nevada, 1996b, "Gamma Ray Spectrometry Operations,” L-E10.602.PC, Las Vegas, NV.

Bechtel Nevada, 1996c, "Bechtel Nevada Waste Certification Program Plan for Radioactive Waste Storage or Disposal," Las Vegas, NV.

Bechtel Nevada, 1998a, "Radioactive Waste Tracking, Handling, and Management at the NTS," L-E10.308.WWC, Las Vegas, NV.

Bechtel Nevada, 1998b, “General Monitoring Practices Manual,” L-A14.107.H, Revision 1, Las Vegas, NV.

Bechtel Nevada, 1999a, Field Management Plan for Corrective Action Unit No. 109: U-2bu Subsidence Crater Nevada Test Site, Nevada, Las Vegas, NV.

Bechtel Nevada, 1999b, Site Specific Health and Safety Plan for Corrective Action Unit No. 109: U2bu Subsidence Crater. Nevada Test Site, Nevada, Las Vegas, NV.

DOE, see U.S. Department of Energy.

EPA, see U.S. Environmental Protection Agency.

Federal Facility Agreement and Consent Order (FFACO) of 1996. Prepared by Nevada Division of Environmental Protection, U.S. Department of Energy, and U.S. Department of Defense.

NAC, see Nevada Administrative Code.

NDEP, see Nevada Division of Environmental Protection.

Nevada Administrative Code, 1996a, NAC 445A, Disposal and Evaluation of Contaminated Soil, Carson City, NV.

Nevada Administrative Code, 1996b, NAC 459.9974, Corrective Action, Carson City, NV. 
Nevada Division of Environmental Protection, 1995, Permit For a Hazardous Waste Facility, Permit Number NEV HW009.

REECo, see Reynolds Electrical and Engineering Co., Inc.

Resource Conservation and Recovery Act, 1976, 42 U.S. Code $\$ \S 6901$ to $6992 k$.

Reynolds Electrical and Engineering Co., Inc., 1995, Nevada Test Site Performance Objective for Certification of Nonradioactive Hazardous Waste, Mercury, NV.

U.S. Department of Energy, Nevada Operations Office, 1989, Offsite Radiation Exposure Review Project, Phase II Soils Programs, DOE/NV/1038-423, Las Vegas, NV

U.S. Department of Energy, Nevada Operations Office, 1994, Nevada Test Site Grid Map, EG\&G Remote Sensing Laboratory, Las Vegas, NV.

U.S. Department of Energy, Nevada Operations Office, 1996, Nevada Test Site Waste Acceptance Criteria, Las Vegas, NV.

U.S. Department of Energy, Nevada Operations Office, 1998a, Characterization Report for Corrective Action Unit 109: Area 2 U-2bu Crater, Nevada Test Site, Nevada, Revision 1, DOE/NV-517, Las Vegas, NV.

U.S. Department of Energy, Nevada Operations Office, 1998b, "Sampling Equipment Decontamination," Revision 1, ERD-05-701, Las Vegas, NV.

U.S. Department of Energy, Nevada Operations Office, 1999a, Closure Plan for Corrective Action Unit 109: Area 2 U-2bu Subsidence Crater, Nevada Test Site, Nevada, Revision 0, DOE/NV/11718--291, Las Vegas, NV.

U.S. Department of Energy, Nevada Operations Office, 1999b, NV/YMP Radiological Control Manual, Revision 3, DOE/NV/11718-079, Las Vegas, NV.

U.S. Environmental Protection Agency, 1996a, Region IX Preliminary Remediation Goals (PRGs), San Francisco, CA.

U.S. Environmental Protection Agency, 1996b, Title 40 Code of Federal Regulations 261.24, "Toxicity Characteristic," Washington, D.C.

U.S. Environmental Protection Agency, 1996c, Title 40 Code of Federal Regulations 264.280, "Closure and Post-Closure Care," Washington, D.C. 
U.S. Environmental Protection Agency, 1996d, Title 40 Code of Federal Regulations 270.1, "EPA Administered Permit Programs: The Hazardous Waste Permit Program, Subpart A - General Information," Washington, D.C.

U.S. Environmental Protection Agency, 1996e, Test Methods for Evaluating Solid Waste Physical/Chemical Methods (SW-846). Third Edition, Washington, D.C.

U.S. Environmental Protection Agency, 1996f, Title 40 Code of Federal Regulations 264.115, "Certification of Closure," Washington, D.C. 
THIS PAGE INTENTIONALLY LEFT BLANK 
APPENDIX A

\section{CLOSURE CERTIFICATION}


THIS PAGE INTENTIONALLY LEFT BLANK 


\section{CERTIFICATION OF CLOSURE BY THE U.S. DEPARTMENT OF ENERGYINEVADA OPERATIONS OFFICE}

I certify under penalty of law that the U-2bu Subsidence Crater, Corrective Action Unit 109, located in Area 2 at the Nevada Test Site has been closed in accordance with the approved Closure Plan for Corrective Action Unit 109: U-2bu Subsidence Crater. Nevada Test Site, Nevada, dated March 1999. All measures required in the Closure Plan and the applicable Resource Conservation and Recovery Act 42 U.S.C. 6901-6991i and the Title 40 CFR 260-270 have been fully implemented and that, to the best of my knowledge, no violations exist.

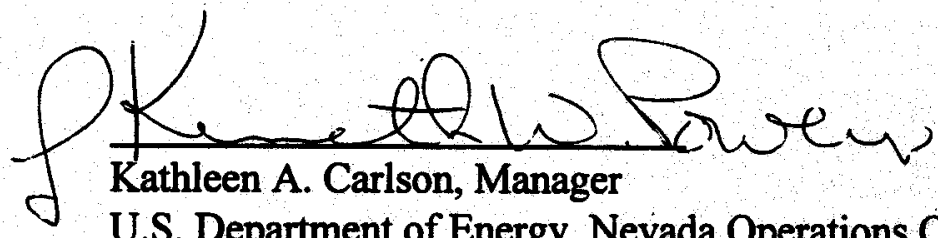

U.S. Department of Energy, Nevada Operations Office

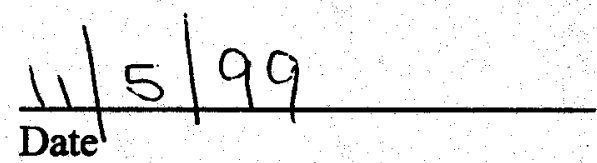

U.S. Department of Energy, Nevada Operations Office Post Office Box 98518

Las Vegas, Nevada 89193-8518 


\section{CERTIFICATION OF CLOSURE BY THE INDEPENDENT PROFESSIONAL ENGINEER}

I, Dean D. Nelson, a registered Professional Engineer, hereby state that I have reviewed the Closure Plan for the closure of the U-2bu Subsidence Crater, Corrective Action Unit 109, located in Area 2 of the Nevada Test Site and am familiar with the rules and regulations of Title 40 CFR $\$ 264.280(e)$ and $\$ 270.1(c)(5)$ and (6) pertaining to the clean closure of such a facility. The closure of this facility has been performed in compliance with the approved Closure Plan for Corrective Action Unit No. 109, Area U-2bu Subsidence Crater, Nevada Test Site, Nevada, dated March 1999, accepted as noted in section 2.2 of this report, and the Permit for a Hazardous Waste Management Facility Number NEV HW009, dated March 27, 1995.

Dean D. Nelson

Nevada Professional Engineer (Civil)

License Number 012733

PEER Consultants, P.C.

2439 Losee Road, Suite $1 C$

North Las Vegas, Nevada 89030-4165 
APPENDIX B

WASTE MANIFESTS 


\section{UNIFORM HAZARDOUS WASTE MANIFEST}

3. Generator's Name and Mailing Address

Bechtel Nevada for USDOE

P.0. Box 98521

Las Vegas, Nexada

4. Generator's Phone (703 da, 89193-8521

4. Generators Phone ( 102 Transporter 1 Company Name
Bechtel Nevada for USDOE

Waste Management, NTS, Zone 2

Mercury, Nevada 89023
1. Generator's US EPA ID No.

NV $V 388900090$

\section{Manifest}

Document No. 1000003
2. Page 1 Information in the shaded areas is not required by Federal law.

\begin{tabular}{|c|c|c|c|c|c|c|c|}
\hline \multicolumn{3}{|r|}{ 11. US DOT Description (Including Proper Shipping Name, Hazard Class and ID Number) } & \multicolumn{2}{|c|}{ 12. Containers } & $\begin{array}{c}13 . \\
\text { Total } \\
\text { Quantity } \\
\end{array}$ & \begin{tabular}{|c|}
$14:$ \\
unit \\
wivol
\end{tabular} & Wasto No. \\
\hline a. & $x$ & $\begin{array}{l}\text { Hazardous Waste, Solid, N.0.S., 9, NA3077, III, } \\
\text { (Lead) }\end{array}$ & 10 & C M & 2476 & $P$ & D008 \\
\hline b. & & & & & & & \\
\hline c. & & . & & & & & +1 \\
\hline d. & & & & & & & 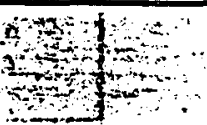 \\
\hline \multicolumn{4}{|c|}{ 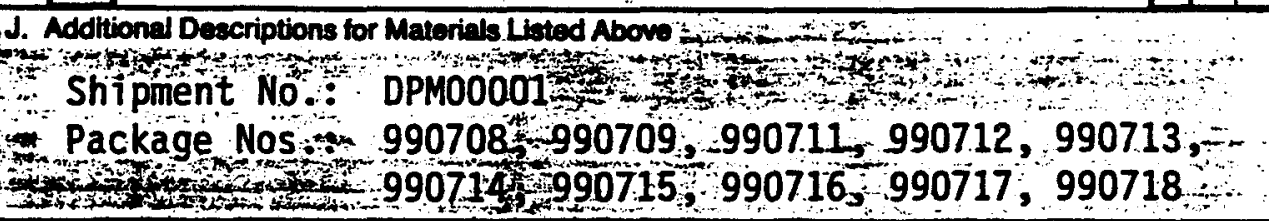 } & \multicolumn{4}{|c|}{ K. Handling Codes for Wastes Listed Above } \\
\hline
\end{tabular}

15. Special Handling Instructions and Additional Information

Emergency Response Guide No.: 171

16. GENERATOF'S CEFIIFCAMON: I hereby declare that the contents of this consignment are fully and accurately described above by

proper shipping name and are ctasesitied, packod, marked, and labeled, and are in all respects in proper condition for transport by highway

according to applicable international and national government regulations.

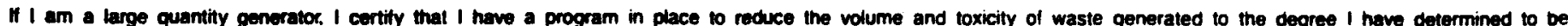

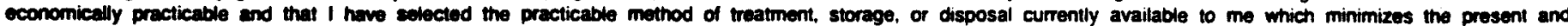

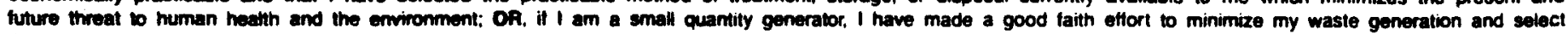
the bost waste managemont mothod that is available to me and that I can afford.

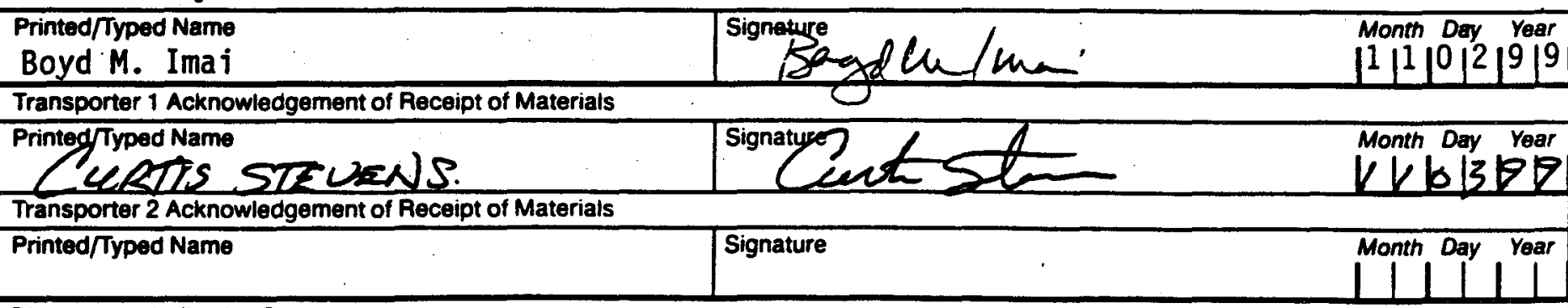

19. Discrepancy Indication Space

20. Facility Owner or Operator: Certification of receipt of hazardous materials covered by this manifest except as noted in Item 19. Printed/Typed Name 70 <e 
Certificate of Disposal

This is to certify that shipment DPM00001, U2bu / Lead Contaminated Soils, Waste Stream No. LRY5-MWFY99014, container numbers 990708. 990709, 990711, 990712, 990713, 990714, 990715, 990716, 990717 , and 990718 were shipped to and received at the Nevada Test Site Radioactive Waste Management Site in Area 5 on this date for disposal.

$\frac{\text { Boyd M. Imai }}{\text { Shipped By }}$
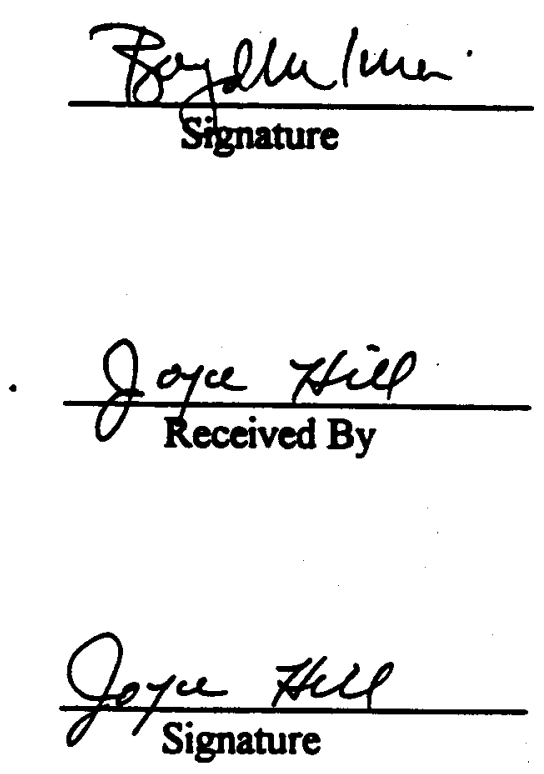

Bechtel Nevada

Waste Minimization and Control

Organization

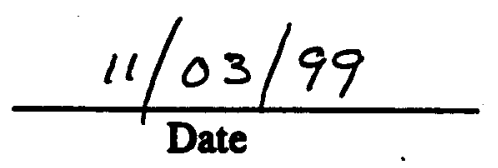

$\frac{B N}{\text { Organization }}$

$\frac{1 / 2-99}{\text { Date }}$
Scientist

Title

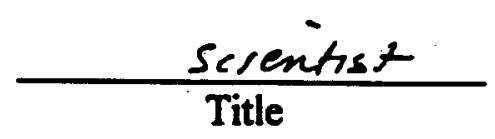


APPENDIX C

TEST RESULTS 
THIS PAGE INTENTIONALLY LEFT BLANK 


\section{NEL LABORATORIES}

\begin{tabular}{|c|c|c|c|c|c|c|}
\hline $\begin{array}{l}\text { CLIENT: } \\
\text { PROJECT D: } \\
\text { PROEECT \#: } \\
\text { TEST: } \\
\text { MATRX: }\end{array}$ & $\begin{array}{l}\text { Beobrel Nevada } \\
\text { VS88/17777 } \\
17777 \\
\text { RCRA } 7 \text { Meols } \\
\text { Aqueons }\end{array}$ & $e^{4}+4$ & & $\begin{array}{l}\text { AIEAT D. } \\
\text { DATE SAMPLDD: } \\
\text { NEL SAMPLE D: }\end{array}$ & $\begin{array}{l}\text { Inpos99 } \\
2 / 2499 \\
\text { L9903009-14 } \\
\text { Y - Reno Divition }\end{array}$ & \\
\hline 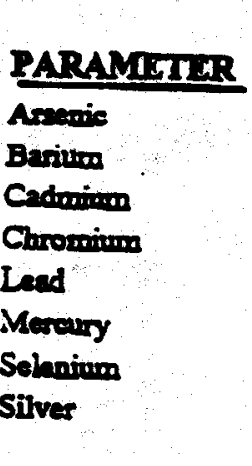 & $\begin{array}{l}\text { RKSULT } \\
\text { MELL } \\
\text { ND } \\
\text { ND } \\
\text { ND } \\
\text { ND } \\
\text { ND } \\
\text { ND } \\
\text { ND } \\
\text { ND }\end{array}$ & 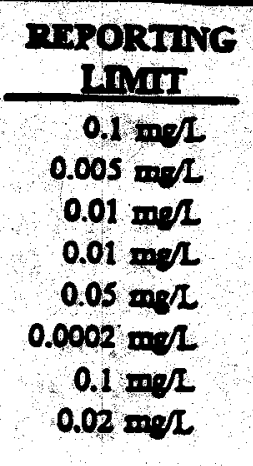 & $\begin{array}{l}\text { D.F. } \\
1 \\
1 \\
1 \\
1 \\
1 \\
1 \\
1\end{array}$ & $\begin{array}{l}\text { VIMP10D } \\
\text { EPA } 6010 \\
\text { EPA } 6010 \\
\text { EPA } 6010 \\
\text { EPA 6010 } \\
\text { EPA 6010 } \\
\text { EPA7470A } \\
\text { EPA 6010 } \\
\text { EPA } 6010\end{array}$ & $\begin{array}{c}\text { DIGISTIPD } \\
3 / 2 / 99 \\
3 / 2 / 99 \\
3 / 2 / 99 \\
3 / 2 / 99 \\
3 / 2 / 99 \\
3 / 9 / 99 \\
3 / 2 / 99 \\
3 / 2 / 99\end{array}$ & $\begin{array}{c}\text { ANATYYZWD } \\
3 / 3 / 99 \\
3 / 3 / 99 \\
3 / 3 / 99 \\
3 / 3 / 99 \\
3 / 3 / 99 \\
3 / 9199 \\
3 / 3 / 99 \\
3 / 3 / 99\end{array}$ \\
\hline
\end{tabular}

F. - Dilurion Factor

J- Not Detected

is report shall not be reproduced except in fill, without the written approvel of the laboratong. 


\begin{tabular}{|c|c|c|c|}
\hline $\begin{array}{l}\text { CLIENT: } \\
\text { BROJECT D: } \\
\text { PROJECT \#: }\end{array}$ & $\begin{array}{l}\text { Bechtel Nevada } \\
\text { V588/17777 } \\
1777\end{array}$ & $\begin{array}{l}\text { CIIENT D: } \\
\text { DATE SAMPIED: } \\
\text { NEI SAMPLE ID: }\end{array}$ & $\begin{array}{l}\text { Method Blank } \\
\text { NA } \\
\text { L03009-R7-BLK }\end{array}$ \\
\hline TEST: & RCRA 7 Metals & & \\
\hline
\end{tabular}

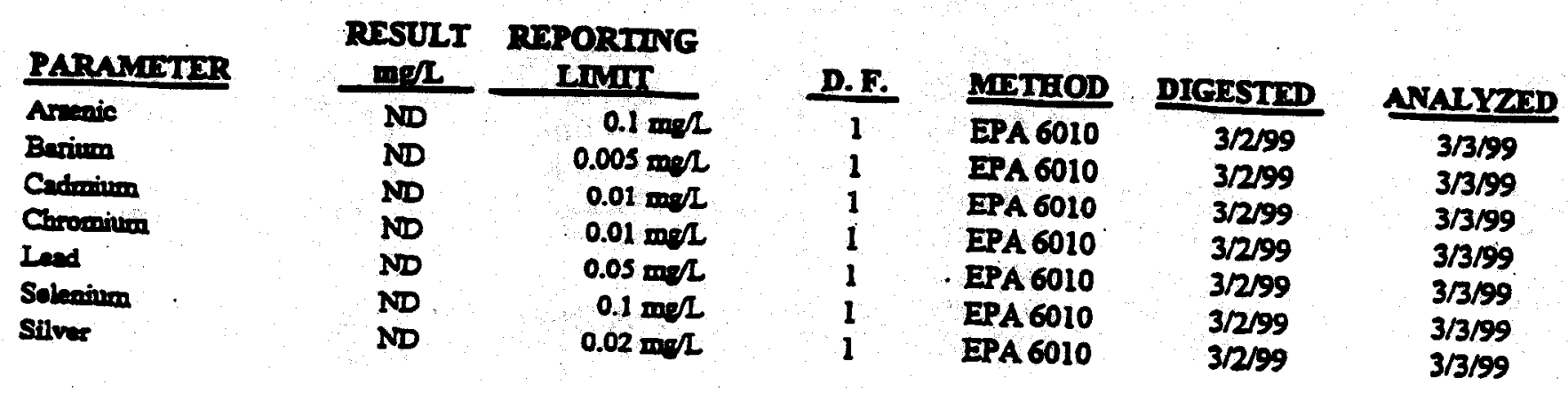

D.F. - Dilution Pactor

ND - Not Detected

Thus report shall not be reproduced except in full, without the writhen opproval of the laboratory. 


\section{NEL LABORATORIES}

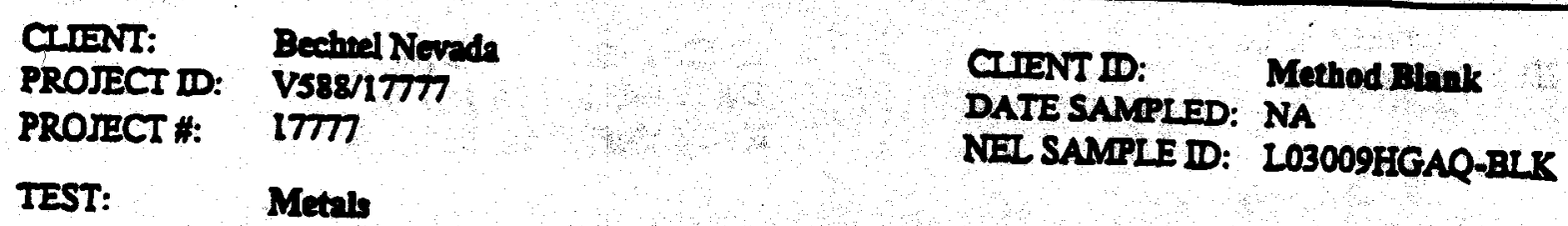

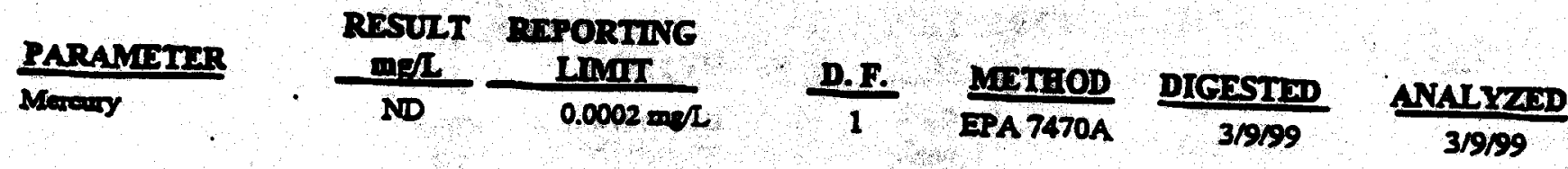

D.F. - Dilution Facur

ND-Not Derected

This report shall not be reproduced except in full, without the writhen cpppoval of the laboretory. 
CLIENT: Bechtel Nevada

PROJECT D: VS88/17777

PROJECT \#: 17777

TEST: TCLP\& Matals

MATRR: Solid
CTRNT D:

DATE SAMPLED: 2/2499

NEI SAMPLE ID: L9903009-01

\begin{tabular}{|c|c|c|c|c|c|c|c|}
\hline PARANITIMR & $\begin{array}{l}\text { RXSULT } \\
\text { moג } \\
\end{array}$ & $\begin{array}{c}\text { RMPORIMI } \\
\text { LMII }\end{array}$ & D. $\mathbf{E}$. & MITHOD & $\begin{array}{l}\text { TCLPATLC } \\
\text { DARACTION } \\
\text { DATE }\end{array}$ & DIG25TMO & ANAIXZaD \\
\hline $\begin{array}{l}\text { Aremie } \\
\text { Enrivem }\end{array}$ & ND & $0.1 \mathrm{mos}$ & 1 & EPA 6010 & 3/3/99 & $3 / 499$ & $3 / 499$ \\
\hline Cadminim & ND & $\begin{array}{l}1 . \mathrm{mel} / 2 \\
0.01 \mathrm{~mol}\end{array}$ & 1 & EPA 6010 & $3 / 3 / 99$ & $3 / 4 / 99$ & $3 / 4 / 99$ \\
\hline Chromines & ND & $0.01 \operatorname{med}$ & 1 & EPA 6010 & $3 / 3 / 99$ & $3 / 4 / 99$ & $3 / 4 / 99$ \\
\hline Lead & ND & $0.05 \mathrm{mo} / \mathrm{L}$ & 1 & $\begin{array}{l}\text { BPA } 6010 \\
\text { EPA } 6010\end{array}$ & $3 / 3 / 99$ & 3/4/99 & $3 / 4 / 99$ \\
\hline Merewy & ND & $0.002 \mathrm{mos} /$ & 10 & $\begin{array}{l}\text { EPA } 6010 \\
\text { EPA } 7470 A\end{array}$ & 3/3/99 & $3 / 4 / 99$ & $3 / 4 / 99$ \\
\hline Sabninem & ND & $0.1 \mathrm{mg} 2$ & 1 & $\begin{array}{l}\text { EPA 7470A } \\
\text { EPA 6010 }\end{array}$ & $3 / 3 / 99$ & $3 / 4 / 99$ & $3 / 4 / 99$ \\
\hline Silver & ND & $0.02 \operatorname{mos} \lambda$ & 1 & $\begin{array}{l}\text { EPA } 6010 \\
\text { EPA } 6010\end{array}$ & $\begin{array}{l}3 / 3 / 99 \\
3 / 3 / 99\end{array}$ & $3 / 4 / 99$ & $3 / 4 / 99$ \\
\hline
\end{tabular}

.P. - Dilution Factor

D-Not Derected

is report shall not be reproduced except in full, without the written approval of the laboratory. 


\begin{tabular}{|c|c|c|}
\hline $\begin{array}{l}\text { PROJECT ID: } \\
\text { PROJECT } \\
\text { F: }\end{array}$ & $\begin{array}{l}\text { Bechrel Nevada } \\
\text { Vs88/17777 } \\
17777\end{array}$ & $\begin{array}{l}\text { CLIENT ID: } \\
\text { DATE SAMPL ED: 2/2499 GP-NS } \\
\text { NEI SAMPLE D: L9903009-02 }\end{array}$ \\
\hline $\begin{array}{l}\text { TEST: } \\
\text { MATRDX: }\end{array}$ & $\begin{array}{l}\text { TCLPA Metals } \\
\text { Solid }\end{array}$ & \\
\hline
\end{tabular}

\begin{tabular}{|c|c|c|c|c|c|c|c|}
\hline PARAMETMR & $\begin{array}{l}\text { RSSULT } \\
\text { meL }\end{array}$ & $\begin{array}{l}\text { RTPORIMG } \\
\text { LDMT }\end{array}$ & D. $E$. & NinaO & $\begin{array}{c}\text { TCLPSTLC } \\
\text { DXXYCTION } \\
\text { DATE } \\
\end{array}$ & DIGISTID & ANALYZASD \\
\hline $\begin{array}{l}\text { Arraic } \\
\text { Berinm }\end{array}$ & $\begin{array}{l}\text { ND } \\
\text { ND }\end{array}$ & $0.1 \mathrm{~mol}$ & 1 & BPA 6010 & $3 / 3 / 99$ & $3 / 4 / 99$ & $3 / 4 / 99$ \\
\hline Codrinim & ND & $\begin{array}{r}1 . \mathrm{meg} / \\
0.01 \mathrm{mg} / 2\end{array}$ & 1 & $\begin{array}{l}\text { EPA } 6010 \\
\text { EPA } 6010\end{array}$ & $3 / 3 / 99$ & $3 / 4 / 99$ & $3 / 4 / 99$ \\
\hline Chrominen & ND & $0.01 \mathrm{men}$ & 1 & $\begin{array}{l}\text { EPA } 6010 \\
\text { EPA } 6010\end{array}$ & 3/3/99 & $3 / 4 / 99$ & $3 / 4 / 99$ \\
\hline Land & ND & $0.05 \mathrm{mo} / \mathrm{L}$ & 1 & $\begin{array}{l}\text { EAA } 0010 \\
\text { EPA } 6010\end{array}$ & 3/3/99 & $3 / 4 / 99$ & $3 / 4 / 99$ \\
\hline Mereury & ND & $0.002 \mathrm{~mol} /$ & 10 & EPA 7470A & $\begin{array}{l}3 / 3 / 99 \\
3 / 3 / 09\end{array}$ & $3 / 4 / 99$ & $3 / 4 / 99$ \\
\hline Seloninem & ND & 0.1 mes & 1 & EPA 6010 & $3 / 3 / 99$ & $3 / 4 / 99$ & $3 / 4 / 99$ \\
\hline Silver & ND & $0.02 \mathrm{~mm} /$ & 1 & BPA 6010 & $\begin{array}{l}3 / 3 / 99 \\
3 / 3 / 99\end{array}$ & $\begin{array}{l}3 / 4 / 99 \\
3 / 4 / 99\end{array}$ & $\begin{array}{l}3 / 4 / 99 \\
3 / 4 / 99\end{array}$ \\
\hline
\end{tabular}

F. - Dilution Factor

\section{J- Not Detected}

tis report shall nat be reproduced except in full, without the written approval of the laboraton. 


\section{NEL LABORATORIES}

CIIENT: Bechrel Nevada

PROJECT ID: V588/17777

PROJECT \#: 17777

TEST: TCLP-8 Metals

MATRE: Solid
ClIENT ID: U-2bo GP-N7

DATE SAMPLED: 2/2499

NEL SAMPLE ID: L9903009-03

\begin{tabular}{|c|c|c|c|c|c|c|c|}
\hline PARAMETER & $\begin{array}{l}\text { RTSULT } \\
\text { moL }\end{array}$ & $\begin{array}{l}\text { PXPORTIIG } \\
\text { LMII }\end{array}$ & D.E. & METEOD & $\begin{array}{l}\text { TCIPSILC } \\
\text { DXTACIION } \\
\text { DATE }\end{array}$ & DIGSSTM & ANALYZaD \\
\hline $\begin{array}{l}\text { Armemic } \\
\text { Berivm }\end{array}$ & ND & $0.1 \mathrm{mel}$ & 1 & BPA 6010 & 3/3/99 & $3 / 4 / 99$ & $3 / 4 / 99$ \\
\hline Cadinims & $\begin{array}{l}\text { ND } \\
\text { ND }\end{array}$ & $\begin{array}{l}1 . \mathrm{mel} \\
0.01 \mathrm{mel}\end{array}$ & 1 & EPA 6010 & $3 / 3 / 99$ & $3 / 4 / 99$ & $3 / 4 / 99$ \\
\hline Ohrominum & ND & $0.01 \mathrm{~mol}$ & 1 & $\begin{array}{l}\text { EPA } 6010 \\
\text { EPA } 6010\end{array}$ & $3 / 3 / 99$ & $3 / 4 / 99$ & $3 / 4 / 99$ \\
\hline Loed & ND & $0.05 \mathrm{mg} / 2$ & 1 & $\begin{array}{l}\text { EPA } 6010 \\
\text { EPA } 6010\end{array}$ & $3 / 3 / 99$ & $3 / 4 / 99$ & $3 / 4 / 99$ \\
\hline Mereury & ND & $0.002 \mathrm{mog} /$ & 10 & $\begin{array}{c}\text { EPA } 6010 \\
\text { EPA 7470A }\end{array}$ & $3 / 3 / 99$ & $3 / 4 / 99$ & $3 / 4 / 99$ \\
\hline Selenimen & ND & $0.1 \mathrm{mg} / \mathrm{L}$ & 1 & $\begin{array}{l}\text { EPA 7470A } \\
\text { EPA 6010 }\end{array}$ & $3 / 3 / 99$ & $3 / 4 / 99$ & $3 / 4 / 99$ \\
\hline Silver & ND & $0.02 m=\pi$ & 1 & $\begin{array}{l}\text { EPA } 6010 \\
\text { EPA } 6010\end{array}$ & $\begin{array}{l}3 / 3 / 99 \\
3 / 3 / 99\end{array}$ & $\begin{array}{l}3 / 4 / 99 \\
3 / 4 / 99\end{array}$ & $\begin{array}{l}3 / 4 / 99 \\
3 / 4 / 99\end{array}$ \\
\hline
\end{tabular}

F. - Dilution Factor

J - Nor Detected

tis report shall not be reprodiced except in full, without the writen approval of the laborators. 


\begin{tabular}{|c|c|c|}
\hline $\begin{array}{l}\text { CLENT: } \\
\text { PROJECT D: } \\
\text { PROJECT \#: }\end{array}$ & $\begin{array}{l}\text { Bechtel Noveda } \\
\text { Vs88/17777 } \\
17777\end{array}$ & $\begin{array}{l}\text { CLIENI D: } \quad \text { U-26V GP-N10 } \\
\text { DATE SAMPLED: } 2 / 2499 \\
\text { NEL SAMPLE ID: L9903009-04 }\end{array}$ \\
\hline $\begin{array}{l}\text { TEST: } \\
\text { MATRE: }\end{array}$ & $\begin{array}{l}\text { TCLP-8 Metals } \\
\text { Solid }\end{array}$ & \\
\hline
\end{tabular}

\section{PARAMTIER}

Arwanic

Barines

Cadrinim

Chroming

Lead

Marcory

Solvonimon

Silver

TCLP-8 Metols

TCLPSTLC

EXTRACTION

DATE DIGESTIDD ANATYZATD

$.3 / 3 / 99$

$3 / 3 / 99$

$3 / 3 / 99$

$3 / 3 / 99$

3/3/99

3/3/99

$3 / 3 / 99$

$3 / 3 / 99$

$\begin{array}{ll}3 / 4 / 99 & 3 / 4 / 99 \\ 3 / 4 / 99 & 3 / 4 / 99 \\ 3 / 4 / 99 & 3 / 4 / 99 \\ 3 / 4 / 99 & 3 / 4 / 99 \\ 3 / 4199 & 3 / 4 / 99 \\ 3 / 4 / 99 & 3 / 4 / 99 \\ 3 / 4 / 99 & 3 / 4 / 99 \\ 3 / 4 / 99 & 3 / 4 / 99\end{array}$

F. - Dilution Pactor

3- Not Detected

is report shall not be reproduced except in full, withour the writuen approval of the laboratory. 


\section{CIINT: Bechiel Nevada \\ PROJECT D: VS88/17777 \\ PROJECT \#: 1777}

TEST: TCLP\&Metals

MATRE: Solid

\section{Clmant ID: U-2br GP-JI}

DATE SAMPLED: 2/24/99

NEI SAMPLE D: L9903009-05

\begin{tabular}{|c|c|c|c|c|c|c|c|}
\hline PARAMTTIXR & $\begin{array}{l}\text { RNSULT } \\
\text { चgLL }\end{array}$ & $\begin{array}{l}\text { REPORIMNG } \\
\text { LIMIT }\end{array}$ & D.E. & MITIEOS & $\begin{array}{c}\text { TCLPSTIC } \\
\text { DXIRACIION } \\
\text { DATE } \\
\end{array}$ & Dressixn & ANAIYZADD \\
\hline $\begin{array}{l}\text { Aneris } \\
\text { Berium }\end{array}$ & $\begin{array}{l}\text { ND } \\
\text { ND }\end{array}$ & $\begin{array}{l}0.1 \mathrm{~m} / L \\
1 . \mathrm{mol}\end{array}$ & 1 & EPA 6010 & $3 / 3 / 99$ & $3 / 499$ & $3 / 4 / 99$ \\
\hline Cadteming & ND & $\begin{array}{l}1 . \mathrm{mg} / \mathrm{L} \\
0.01 \mathrm{mel}\end{array}$ & 1 & $\begin{array}{l}\text { EPA } 6010 \\
\text { EPA } 6010\end{array}$ & $3 / 3 / 99$ & $3 / 4 / 99$ & $3 / 4 / 99$ \\
\hline Corominen & ND & $0.01 \mathrm{men}$ & 1 & $\begin{array}{l}\text { EPA } 6010 \\
\text { EPA } 6010\end{array}$ & $3 / 3 / 99$ & $3 / 4 / 99$ & $3 / 499$ \\
\hline Laed. & ND & $0.05 \mathrm{man} / \mathrm{L}$ & 1 & $\begin{array}{l}\text { EPA } 6010 \\
\text { EPA } 6010\end{array}$ & $3 / 3 / 99$ & $3 / 4 / 99$ & $3 / 4 / 99$ \\
\hline Merengy & ND & $0.002 \mathrm{mog} / \mathrm{L}$ & 10 & EPA 7470A & $3 / 3 / 99$ & $3 / 4 / 99$ & $3 / 4 / 99$ \\
\hline Solminem & ND & $0.1 \mathrm{mg} / \mathrm{L}$ & 1 & BPA 6010 & 3/3/99 & $3 / 4 / 99$ & $3 / 4 / 99$ \\
\hline Silver & ND & $0.02 \mathrm{me} / \mathrm{L}$ & 1 & EPA 6010 & $\begin{array}{l}3 / 3 / 99 \\
3 / 3 / 99\end{array}$ & $3 / 4 / 99$ & $3 / 4 / 99$ \\
\hline
\end{tabular}

F. - Dilution Factor

D - Not Delected

is report shall not be reproduced except in full, wizhout the written opproval of the laboratory. 


\begin{tabular}{|c|c|c|}
\hline $\begin{array}{l}\text { CIIENT: } \\
\text { PROJECT ID: } \\
\text { PROJECT \#: }\end{array}$ & $\begin{array}{l}\text { Bechtel Novads } \\
\text { Vs88117777 } \\
17777\end{array}$ & $\begin{array}{l}\text { CLIENT D: } \\
\text { DATE SAMPLED: } 2 / 2499 \\
\text { NEI SAMPLE ID: L9903009-06 }\end{array}$ \\
\hline $\begin{array}{l}\text { TEST: } \\
\text { MATRD: }\end{array}$ & $\begin{array}{l}\text { TCLP \& Metnls } \\
\text { Solid }\end{array}$ & \\
\hline
\end{tabular}

\begin{tabular}{|c|c|c|c|c|c|c|c|}
\hline PARAMITISR & $\begin{array}{c}\text { RISULT } \\
\text { mRL }\end{array}$ & $\begin{array}{c}\text { RXPORIMG } \\
\text { LIMIX }\end{array}$ & D.. & METEOD & $\begin{array}{c}\text { TCIPAYIC } \\
\text { IXEACIION } \\
\text { DAIE }\end{array}$ & DIGXSTIX & ANATYZaD \\
\hline $\begin{array}{l}\text { Arenaic } \\
\text { Berium }\end{array}$ & ND & $0.1 \mathrm{men}$ & 1 & EPA 6010 & $3 / 3 / 99$ & $3 / 4 / 99$ & $3 / 4 / 99$ \\
\hline Cadtonimen & ND & $\begin{array}{r}\text { 1. } \mathrm{mg} / \mathrm{L} \\
0.01 \mathrm{mg} / \mathrm{L}\end{array}$ & 1 & EPA 6010 & $3 / 3 / 99$ & $3 / 499$ & $3 / 4499$ \\
\hline Chromines & ND & $\begin{array}{l}0.01 \mathrm{me} / \\
0.01 \mathrm{mo} /\end{array}$ & 1 & EPA 6010 & $3 / 3 / 99$ & $3 / 4 / 99$ & $3 / 4 / 99$ \\
\hline Leand & ND & $\begin{array}{l}0.01 \mathrm{mg} / \\
0.05 \mathrm{mg} /\end{array}$ & $\begin{array}{l}1 \\
1\end{array}$ & EPA 6010 & $3 / 3 / 99$ & $3 / 4 / 99$ & $3 / 4 / 99$ \\
\hline Mereny & ND & $0.002 \mathrm{mog} \Omega$ & 10 & EPA 6010 & $3 / 3 / 99$ & $3 / 4 / 99$ & $3 / 4 / 99$ \\
\hline Selexiven & ND & $0.1 \mathrm{mg} \Omega$ & 1 & $\begin{array}{l}\text { EPA 7470A } \\
\text { EPA } 6010\end{array}$ & $3 / 3 / 99$ & $3 / 4 / 99$ & $3 / 4 / 99$ \\
\hline Silver & ND & $0.02 \mathrm{mos} / \mathrm{L}$ & 1 & $\begin{array}{l}\text { EPA } 6010 \\
\text { EPA } 6010\end{array}$ & $\begin{array}{l}3 / 3 / 99 \\
3 / 3 / 99\end{array}$ & $\begin{array}{l}3 / 4 / 99 \\
3 / 4 / 99\end{array}$ & $\begin{array}{l}3 / 4 / 99 \\
3 / 4 / 99\end{array}$ \\
\hline
\end{tabular}

F. - Dihrion Factor

)- Not Detected

is report shall not be reproctucad except in full, without the written approval of the laboratong. 


$\begin{array}{ll}\text { CLIENT: } & \text { Bechrel Nevada } \\ \text {. PROJECT ID: } & \text { VS88/17777 } \\ \text { PROJECT *: } & 1777\end{array}$

TEST: TCLP-8 Metals
CIIENT ID:

DATE SAMPLED: $2 / 24199$

NEL SAMPLE ID: L9903009-07

\section{MATRDX: Solid}

\begin{tabular}{|c|c|c|c|c|c|c|c|}
\hline$\frac{\text { PARAMRTER }}{\text { Afmic }}$ & $\begin{array}{c}\text { Rasult } \\
\text { me } 2 \\
\end{array}$ & $\begin{array}{c}\text { IDPORIMNG } \\
\text { LMMT }\end{array}$ & D.E. & MOTIOD & $\begin{array}{c}\text { TCLPSTLC } \\
\text { EXIRACTION } \\
\text { DATE } \\
\end{array}$ & DIGDSTMD & INAIYYAN \\
\hline $\begin{array}{l}\text { Arsanic } \\
\text { Beriven }\end{array}$ & $\begin{array}{l}\text { ND } \\
\text { ND }\end{array}$ & $0.1 \mathrm{me} / \mathrm{L}$ & 1 & EPA 6010 & 3/3/99 & $3 / 4 / 99$ & $3 / 4 / 99$ \\
\hline Codmixum & ND & $\begin{array}{r}1 . \mathrm{mg} / \mathrm{L} \\
0.01 \mathrm{mg} / \mathrm{L}\end{array}$ & 1 & EPA 6010 & $3 / 3 / 99$ & $3 / 4 / 99$ & $3 / 499$ \\
\hline Chrominim & ND & $0.01 \mathrm{mg} / \mathrm{L}$ & 1 & $\begin{array}{l}\text { EPA } 6010 \\
\text { EPA } 6010\end{array}$ & $3 / 3 / 99$ & $3 / 4 / 99$ & $3 / 4 / 99$ \\
\hline Leand & ND & $0.05 \mathrm{mg} / \mathrm{L}$ & 1 & $\begin{array}{l}\text { EPA } 6010 \\
\text { EPA } 6010\end{array}$ & $3 / 3 / 99$ & $3 / 4 / 99$ & $3 / 4 / 99$ \\
\hline Mereary & ND & $0.002 \mathrm{mor}$ & 10 & $\begin{array}{l}\text { EPA } 6010 \\
\text { BPA } 7470 A\end{array}$ & $3 / 3 / 99$ & $3 / 4 / 99$ & $3 / 4 / 99$ \\
\hline Selemixion & $\mathbf{N D}$ & $0.1 \mathrm{~mol}$ & 1 & EPA 7470A & $3 / 3 / 99$ & $3 / 4199$ & $3 / 4 / 99$ \\
\hline Silver & ND & $0.02 \mathrm{mg} / \mathrm{L}$ & $i$ & $\begin{array}{l}\text { EPA } 6010 \\
\text { EPA } 6010\end{array}$ & $\begin{array}{l}3 / 3 / 99 \\
3 / 3 / 99\end{array}$ & $\begin{array}{l}3 / 4 / 99 \\
3 / 4 / 99\end{array}$ & $\begin{array}{l}3 / 4199 \\
3 / 4 / 99\end{array}$ \\
\hline
\end{tabular}

\section{F. - Dilution Factor}

2- Not Decected

is report shall not be neproduced except in full, whout the written opproval of the laboratory. 


\begin{tabular}{|c|c|c|}
\hline $\begin{array}{l}\text { CLIENT: } \\
\text { PROJECI D: } \\
\text { PROJECI } \#:\end{array}$ & $\begin{array}{l}\text { Bechel Nevada } \\
\text { Vs88/17777 } \\
17777\end{array}$ & $\begin{array}{l}\text { CLIENT ID: } \\
\text { DATE SAMPL ED: } 2 / 24 / 99 \\
\text { NEL SAMPLE DD: L9903009-08 }\end{array}$ \\
\hline $\begin{array}{l}\text { TEST: } \\
\text { MATRIX: }\end{array}$ & $\begin{array}{l}\text { TCuP-8 Motals } \\
\text { Solid }\end{array}$ & \\
\hline
\end{tabular}

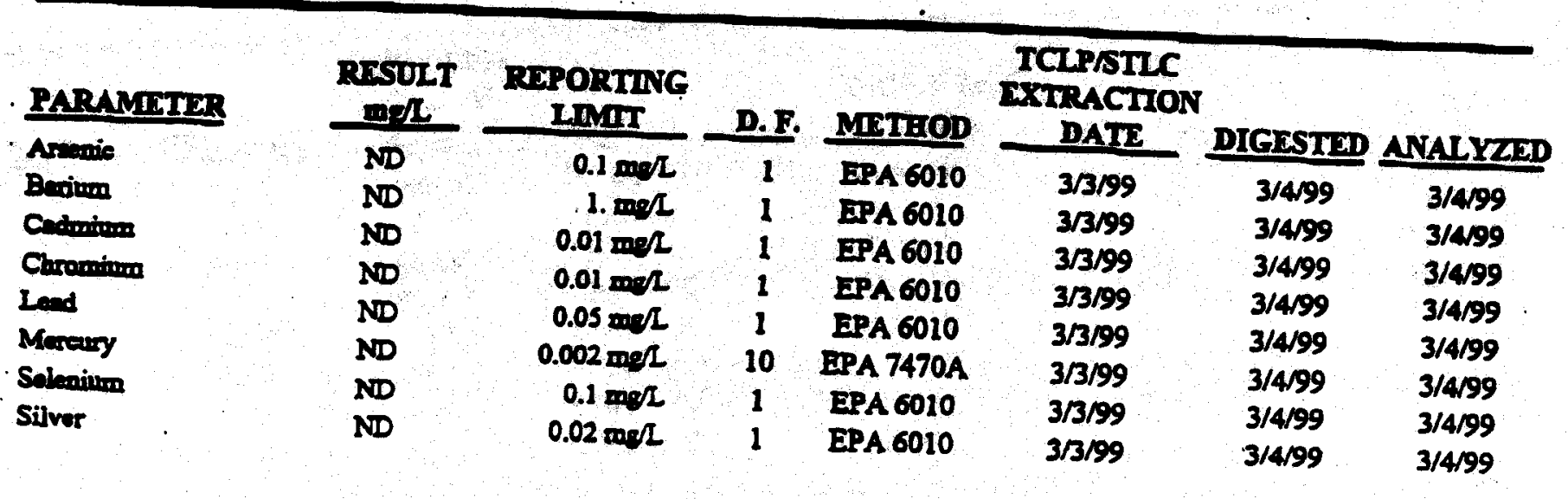




\begin{tabular}{|c|c|c|}
\hline $\begin{array}{l}\text { CIIENT: } \\
\text { PROJECT ID: } \\
\text { PROJECT *: }\end{array}$ & $\begin{array}{l}\text { Bechuel Neveda } \\
\text { V } 588 / 17777 \\
17777\end{array}$ & $\begin{array}{ll}\text { CLIENT I: } & \text { U-26 GP-AI } \\
\text { DATE SAMPLED: 2/24/99 } \\
\text { NEL SAMPLE DD; L9903009-09 }\end{array}$ \\
\hline $\begin{array}{l}\text { TEST: } \\
\text { MATRE: }\end{array}$ & $\begin{array}{l}\text { TCLP-8 Metals } \\
\text { Solid }\end{array}$ & \\
\hline
\end{tabular}

\begin{tabular}{|c|c|c|c|c|c|c|c|}
\hline$\frac{\text { PARAMETXR }}{\text { Annonis }}$ & $\begin{array}{l}\text { EXSOLT } \\
\text { ESL }\end{array}$ & $\begin{array}{c}\text { RMPORTING } \\
\text { IMIIT }\end{array}$ & D. 5 . & MeTron & $\begin{array}{c}\text { TCLPSTLC } \\
\text { ETPACTION } \\
\text { DATI }\end{array}$ & DIGESTXX & ANATYYAX \\
\hline $\begin{array}{l}\text { Arronis } \\
\text { Berivem }\end{array}$ & $\begin{array}{l}\text { ND } \\
\text { ND }\end{array}$ & $0.1 \mathrm{men}$ & 1 & EPA 6010 & $3 / 3 / 99$ & $3 / 4 / 99$ & $3 / 4 / 99$ \\
\hline Cadmingen & ND & $0.01 \operatorname{mon} \Omega$ & 1 & EPA 6010 & $3 / 3 / 99$ & $3 / 4199$ & $3 / 499$ \\
\hline Chroming & ND & $0.01 \mathrm{mod}$ & 1 & EPA 6010 & $3 / 3 / 99$ & $3 / 4 / 99$ & $3 / 4 / 99$ \\
\hline Lead & ND & $0.05 \mathrm{mg} / \mathrm{L}$ & $\begin{array}{l}1 \\
1\end{array}$ & $\begin{array}{l}\text { EPA } 6010 \\
\text { EPA 6010 }\end{array}$ & $3 / 3 / 99$ & $3 / 4 / 99$ & $3 / 4 / 99$ \\
\hline Marewy & ND & $0.002 \mathrm{mel}$ & 10 & $\begin{array}{l}\text { DPA } 6010 \\
\text { EPA } 7470 A\end{array}$ & $3 / 3 / 99$ & $3 / 499$ & $3 / 4 / 99$ \\
\hline Salonines & $\mathbf{N D}$ & $0.1 \mathrm{mel}$ & 1 & $\begin{array}{l}\text { EPA 7470A } \\
\text { EPA } 6010\end{array}$ & $3 / 3 / 99$ & $3 / 4 / 99$ & $3 / 4 / 99$ \\
\hline Silver & ND & $0.02 \mathrm{~m}=2$ & 1 & $\begin{array}{l}\text { EPA } 6010 \\
\text { EPA } 6010\end{array}$ & $\begin{array}{l}3 / 3 / 99 \\
3 / 3 / 99\end{array}$ & $\begin{array}{l}3 / 4 / 99 \\
3 / 4 / 99\end{array}$ & $\begin{array}{l}3 / 4 / 99 \\
3 / 4 / 99\end{array}$ \\
\hline
\end{tabular}

F. - Dimtion Facme

)- Not Detected

is report shall not be reproduced except in full, without the writren approval of the laboratony. 


\begin{tabular}{|c|c|c|}
\hline $\begin{array}{l}\text { CLRENT: } \\
\text { PROJECT ID: } \\
\text { PROIECT \#: }\end{array}$ & $\begin{array}{l}\text { Bechel Nevada } \\
\text { Vs88/17777 } \\
17777\end{array}$ & $\begin{array}{l}\text { CIIENT ID: } \\
\text { DATE SAMPLED: 2/2499 GP-A3 } \\
\text { NEL SAMPLE D: L9903009-10 }\end{array}$ \\
\hline $\begin{array}{l}\text { TEST: } \\
\text { MATRX: }\end{array}$ & $\begin{array}{l}\text { TCLP-8 Metals } \\
\text { Solid }\end{array}$ & \\
\hline
\end{tabular}

\begin{tabular}{|c|c|c|c|c|c|c|c|}
\hline PARAMETIR & $\begin{array}{l}\text { RXSULT } \\
\text { med } \\
\end{array}$ & $\begin{array}{l}\text { REPODXNG } \\
\text { ITNET }\end{array}$ & D. E. & METEOD & $\begin{array}{l}\text { TCLPATLC } \\
\text { EXIRACTION } \\
\text { DATE } \\
\end{array}$ & DIGSSTYOD & ANAIYZXD \\
\hline $\begin{array}{l}\text { Arramic } \\
\text { Berriven }\end{array}$ & $\begin{array}{l}\mathbf{N D} \\
\mathbf{N D}\end{array}$ & $0.1 \mathrm{mel}$ & 1 & EPA 6010 & 3/3/99 & $3 / 4 / 99$ & $3 / 499$ \\
\hline Cendminem & ND & $0.01 \mathrm{me} / \mathrm{L}$ & 1 & $\begin{array}{l}\text { EPA } 6010 \\
\text { EPA } 6010\end{array}$ & $3 / 3 / 99$ & $3 / 4 / 99$ & $3 / 4199$ \\
\hline Chrowinge & ND & $0.01=0 / 1$ & 1 & $\begin{array}{l}\text { EPA } 6010 \\
\text { EPA } 6010\end{array}$ & $3 / 3 / 99$ & $3 / 499$ & $3 / 4 / 99$ \\
\hline Lend & ND & $0.05 \mathrm{~min} / \mathrm{L}$ & 1 & $\begin{array}{l}\text { EPA } 6010 \\
\text { EPA } 6010\end{array}$ & 3/3/99 & $3 / 4 / 99$ & $3 / 4 / 99$ \\
\hline Menewry & ND & $0.002 \mathrm{me} / \mathrm{L}$ & 10 & $\begin{array}{l}\text { EPA } 6010 \\
\text { BPA } 7470 A\end{array}$ & $3 / 3 / 99$ & $3 / 4 / 99$ & $3 / 4 / 99$ \\
\hline Soloningen & ND & $0.1 \mathrm{mg} / \mathrm{L}$ & 1 & $\begin{array}{l}\text { BPA 7470A } \\
\text { EPA } 6010\end{array}$ & $3 / 3 / 99$ & $3 / 4 / 99$ & $3 / 4 / 99$ \\
\hline Silver & ND & $0.02 \mathrm{mg} / \mathrm{L}$ & 1 & EPA 6010 & $\begin{array}{l}3 / 3 / 99 \\
3 / 3 / 99\end{array}$ & $\begin{array}{l}3 / 4 / 99 \\
3 / 4 / 99\end{array}$ & $\begin{array}{l}3 / 4 / 99 \\
3 / 4 / 99\end{array}$ \\
\hline
\end{tabular}




\begin{tabular}{|c|c|c|}
\hline $\begin{array}{l}\text { CLIENI: } \\
\text { PROJECT D: } \\
\text { PROJECT : }\end{array}$ & $\begin{array}{l}\text { Bechel Nevada } \\
\text { V588/17777 } \\
17777\end{array}$ & $\begin{array}{ll}\text { CIENT ID: } & \text { D-26w GPAN } \\
\text { DATE SAMPLED: 2/24199 } \\
\text { NEI SAMPLE ID: L9903009-11 }\end{array}$ \\
\hline $\begin{array}{l}\text { TEST: } \\
\text { MATRDX: }\end{array}$ & $\begin{array}{l}\text { TCRP-8 Metsls } \\
\text { Solid }\end{array}$ & \\
\hline
\end{tabular}

\begin{tabular}{|c|c|c|c|c|c|c|c|}
\hline PARAMTIIR & $\begin{array}{c}\text { ResuLT } \\
\text { meL } \\
\end{array}$ & $\begin{array}{l}\text { RePortarG } \\
\text { LEMT }\end{array}$ & D. E. & METEOD & $\begin{array}{c}\text { TCLPSTLC } \\
\text { IXXRACIION } \\
\text { DATE }\end{array}$ & DIGRSTM & ANAIYZADD \\
\hline & $\begin{array}{l}\text { ND } \\
\text { ND }\end{array}$ & $0.1 \mathrm{me} / \mathrm{L}$ & 1 & EPA6010 & $3 / 3 / 99$ & $3 / 4 / 99$ & $3 / 4 / 99$ \\
\hline Cadminim & ND & $0.01 \mathrm{me} / \mathrm{L}$ & 1 & $\begin{array}{l}\text { EPA } 6010 \\
\text { EPA } 6010\end{array}$ & $3 / 3 / 99$ & $3 / 499$ & $3 / 4 / 99$ \\
\hline Chroming & ND & $0.01 \mathrm{mel}$ & 1 & $\begin{array}{l}\text { EPA } 6010 \\
\text { EPA } 6010\end{array}$ & $3 / 3 / 99$ & $3 / 4 / 99$ & $3 / 4 / 99$ \\
\hline Load & ND & $0.05 \mathrm{me} / \mathrm{L}$ & 1 & $\begin{array}{l}\text { EPA } 6010 \\
\text { EPA } 6010\end{array}$ & $3 / 3 / 99$ & $3 / 4 / 99$ & $3 / 4 / 99$ \\
\hline Mercury. & ND & $0.002 \mathrm{mg} / \mathrm{L}$ & 10 & $\begin{array}{l}\text { EPA 6010 } \\
\text { EPA 7470A }\end{array}$ & 3/3/99 & $3 / 4 / 99$ & $3 / 4 / 99$ \\
\hline Selonim & ND & $0.1 \mathrm{~mol}$ & 1 & $\begin{array}{l}\text { EPA 7470A } \\
\text { EPA } 6010\end{array}$ & $3 / 3 / 99$ & $3 / 4 / 99$ & $3 / 4 / 99$ \\
\hline Silver & ND & $0.02 \mathrm{mg} / \mathrm{L}$ & 1 & EPA 6010 & $\begin{array}{l}3 / 3 / 99 \\
3 / 3 / 99\end{array}$ & $\begin{array}{l}3 / 4 / 99 \\
3 / 4 / 99\end{array}$ & $\begin{array}{l}3 / 499 \\
3 / 4 / 99\end{array}$ \\
\hline
\end{tabular}

F. - Dilution Frowr

) - Not Derected

is report shall not be reppochuced except in full, whthout the writen appovval of the laboratory. 


CIIINT: $\quad$ Bechtel Nevads
PROJECT ID: V588/17777
PROJECT *: 17777

TEST:

MATRD:

TCLP\& Metals

Solid

\section{CLIENT D: U-2bvGR-A7}

DATE SAMTLED: 224199

NEL SAMPLE D: L9903009-12

\begin{tabular}{|c|c|c|c|c|c|c|c|}
\hline$\frac{\text { PAPAMITIXR }}{\text { Arenie }}$ & $\begin{array}{l}\text { RaYUL } \\
\text { EOR } \\
\end{array}$ & $\begin{array}{c}\text { PHPORTMG } \\
\text { LTMT }\end{array}$ & D.E. & MTEOOD & $\begin{array}{l}\text { TCLPSTLC } \\
\text { DTRACIION } \\
\text { DATE }\end{array}$ & DIGLSTED & ANAIYZAND \\
\hline Bunion & $\begin{array}{l}\text { ND } \\
\text { ND }\end{array}$ & $0.1 \mathrm{mel}$ & 1 & BPA 6010 & $3 / 3 / 99$ & $3 / 499$ & $3 / 4 / 99$ \\
\hline Cadmiven & ND & $0.01 \mathrm{me} / \mathrm{L}$ & 1 & $\begin{array}{l}\text { EPA } 6010 \\
\text { EPA } 6010\end{array}$ & $\begin{array}{l}3 / 3 / 99 \\
3 / 3 / 99\end{array}$ & 3/4/99 & $3 / 499$ \\
\hline $\begin{array}{l}\text { Chrowingm } \\
\text { Lead }\end{array}$ & ND & $0.01 \mathrm{~mol}$ & 1 & EPA 6010 & $\begin{array}{l}3 / 3 / 99 \\
3 / 3 / 99\end{array}$ & $3 / 4 / 99$ & $3 / 4 / 99$ \\
\hline $\begin{array}{l}\text { Lead } \\
\text { Mecaury }\end{array}$ & ND & $0.05 \mathrm{mg} / \mathrm{L}$ & $i$ & EPA 6010 & $\begin{array}{l}3 / 3 / 99 \\
3 / 3 / 99\end{array}$ & $3 / 4199$ & $3 / 4 / 99$ \\
\hline $\begin{array}{l}\text { Merwary } \\
\text { Selonimum }\end{array}$ & ND & $0.002 \mathrm{mg} / \mathrm{L}$ & 10 & EPA 7470A & $3 / 3 / 99$ & $\begin{array}{l}3 / 4 / 99 \\
3 / 4 / 99\end{array}$ & $3 / 4 / 99$ \\
\hline Silver & $\begin{array}{l}\text { ND } \\
\text { ND }\end{array}$ & $\begin{array}{l}0.1 \mathrm{mel} \\
0.02 \mathrm{mel}\end{array}$ & $\begin{array}{l}1 \\
1\end{array}$ & $\begin{array}{l}\text { EPA } 6010 \\
\text { EPA } 6010\end{array}$ & $\begin{array}{l}3 / 3 / 99 \\
3 / 3 / 00\end{array}$ & 3/4/99 & $\begin{array}{l}3 / 4 / 99 \\
3 / 4 / 99\end{array}$ \\
\hline & & & & & $3 / 3 / 99$ & $3 / 4 / 99$ & $3 / 4 / 99$ \\
\hline
\end{tabular}

F. - Dilution Factor

J-Not Detected

is report shall not be reproduced except in full, without the writen approval of the laboratory. 


\begin{tabular}{|c|c|c|}
\hline $\begin{array}{l}\text { CLIENT: } \\
\text { PROJECT ID: } \\
\text { PROJECT \#: }\end{array}$ & $\begin{array}{l}\text { Bechrel Nevada } \\
\text { VS88/17777 } \\
17777\end{array}$ & $\begin{array}{l}\text { CLIENT ID: } \quad \text { U-26V GP-A10 } \\
\text { DATE SAMPLED: 2/2499 } \\
\text { NEL SAMPLE D: L9903009-13 }\end{array}$ \\
\hline $\begin{array}{l}\text { TEST: } \\
\text { MATREX: }\end{array}$ & $\begin{array}{l}\text { TCLP-8 Metols } \\
\text { Solid }\end{array}$ & \\
\hline
\end{tabular}

\begin{tabular}{|c|c|c|c|c|c|c|c|}
\hline PARAMITIER & $\begin{array}{c}\text { PaSULT } \\
\text { me } \\
m\end{array}$ & $\begin{array}{l}\text { PAPORTING } \\
\text { LMMT }\end{array}$ & D. 5 . & METHOD & $\begin{array}{c}\text { TCPATC } \\
\text { MRTMACIION } \\
\text { DAME }\end{array}$ & DIGXSTED & ANAIYZLOD \\
\hline $\begin{array}{l}\text { Aperic } \\
\text { Barium }\end{array}$ & $\begin{array}{l}\text { ND } \\
\text { ND }\end{array}$ & $0.1 \mathrm{men}$ & 1 & EPA 6010 & 3/3/99 & $3 / 4 / 99$ & $3 / 4 / 99$ \\
\hline Cadmitura & ND & $0.01 \mathrm{mog} / 2$ & $\begin{array}{l}1 \\
1\end{array}$ & $\begin{array}{l}\text { EPA } 6010 \\
\text { EPA } 6010\end{array}$ & 3/3/99 & $3 / 4 / 99$ & $3 / 4 / 99$ \\
\hline Chrowinem & $\mathbf{N D}$ & $0.01 \mathrm{mpl}$ & 1 & $\begin{array}{l}\text { EPA } 6010 \\
\text { EPA } 6010\end{array}$ & $3 / 3 / 99$ & $3 / 4 / 99$ & $3 / 4 / 99$ \\
\hline Ined & ND & $0.05 \mathrm{mo} / 1$ & 1 & $\begin{array}{l}\text { EPA } 6010 \\
\text { EPA } 6010\end{array}$ & $3 / 3 / 99$ & $3 / 499$ & $3 / 4 / 99$ \\
\hline Marewy & ND & $0.002 \mathrm{mog}$ & 10 & $\begin{array}{r}\text { EPA } 6010 \\
\text { EPA 7470A }\end{array}$ & $3 / 3 / 99$ & $3 / 4 / 99$ & $3 / 4 / 99$ \\
\hline Solening & ND & $0.1-\alpha$ & 1 & $\begin{array}{l}\text { EPA 7470A } \\
\text { EPA 6010 }\end{array}$ & $3 / 3 / 99$ & 3/4/99 & $3 / 4 / 99$ \\
\hline Silver & ND & $0.02 \mathrm{mes}$ & 1 & $\begin{array}{l}\text { EPA } 6010 \\
\text { EPA } 6010\end{array}$ & $\begin{array}{l}3 / 3 / 99 \\
3 / 3 / 99\end{array}$ & $\begin{array}{l}3 / 4 / 99 \\
3 / 4 / 99\end{array}$ & $\begin{array}{l}3 / 4 / 99 \\
3 / 4 / 99\end{array}$ \\
\hline
\end{tabular}

F. - Dilution Factor

) - Not Detected

is report shall not be reproctuced except in full, without the uritten approval of the laboratory. 


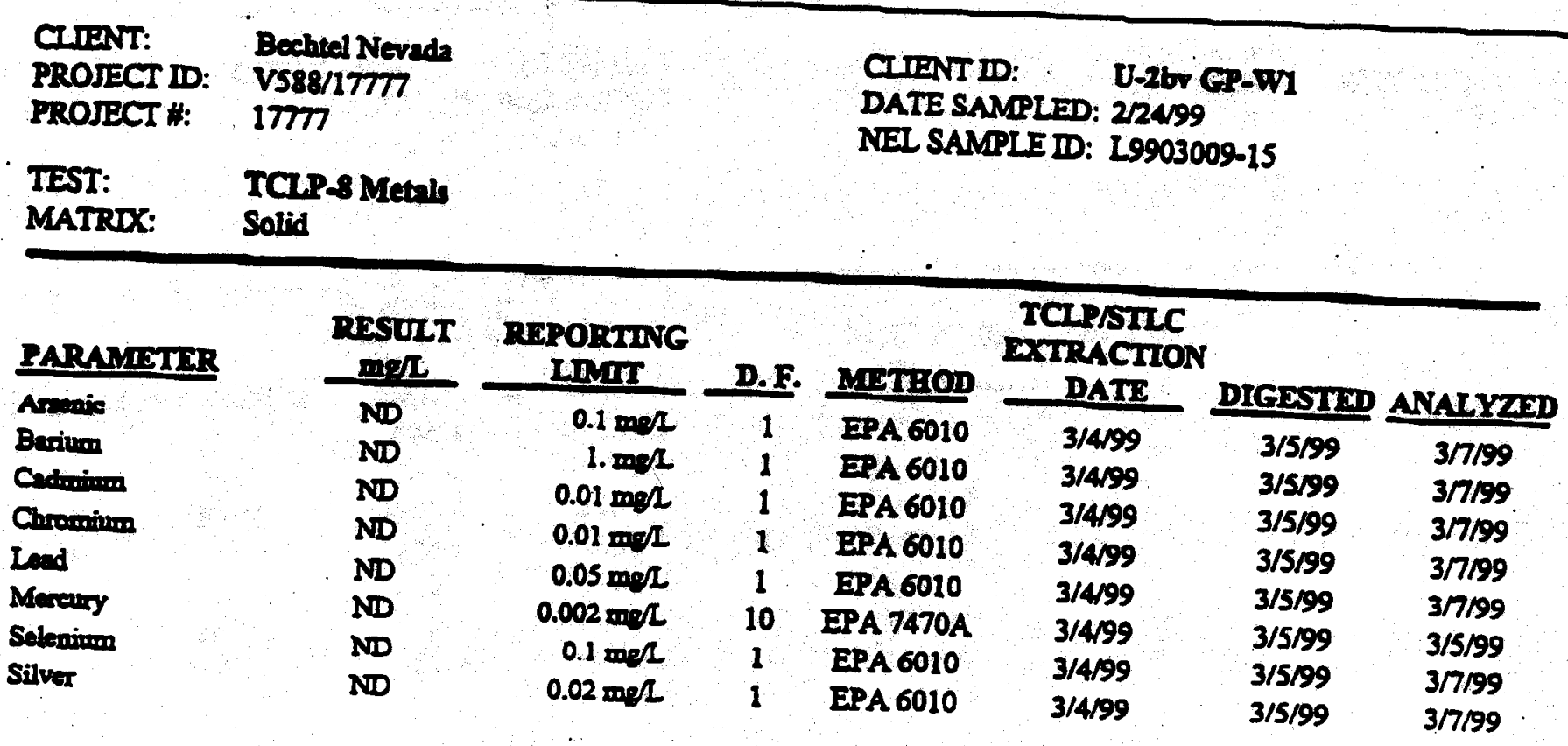




\begin{tabular}{|c|c|c|}
\hline $\begin{array}{l}\text { CRIENT: } \\
\text { PROJECT D: } \\
\text { PROJECT \#: }\end{array}$ & $\begin{array}{l}\text { Bechedel Nerada } \\
\text { V588/17777 } \\
17777\end{array}$ & $\begin{array}{ll}\text { CLIENT ID: } & \text { D-2bV CP-WS } \\
\text { DATE SAMPLED: 2/2499 } \\
\text { NEL SAMPLE DD: L9903009-16 }\end{array}$ \\
\hline $\begin{array}{l}\text { TEST: } \\
\text { MATRDX: }\end{array}$ & $\begin{array}{l}\text { TCLP-8 Metals } \\
\text { Solid }\end{array}$ & \\
\hline
\end{tabular}

\begin{tabular}{|c|c|c|c|c|c|c|c|}
\hline PARAMIATMR & $\begin{array}{l}\text { RRsulT } \\
\text { moL } \\
\end{array}$ & $\begin{array}{l}\text { PXPORTING } \\
\text { LMII }\end{array}$ & D.E. & MISTEOD & $\begin{array}{c}\text { TCLPATLC } \\
\text { EXTRACION } \\
\text { DATE }\end{array}$ & DIGLSTIX & ANAIYZAXN \\
\hline $\begin{array}{l}\text { Arvenic } \\
\text { Barium }\end{array}$ & $\begin{array}{l}\text { ND } \\
\text { ND }\end{array}$ & $0.1 \mathrm{me} /$ & 1 & $\begin{array}{l}\text { EPA } 6010 \\
\text { EPA } 6010\end{array}$ & $3 / 4 / 99$ & $3 / 5 / 99$ & $3 / 7 / 99$ \\
\hline Cedminum & ND & $0.01 \mathrm{mog} / \mathrm{L}$ & 1 & $\begin{array}{l}\text { EPA } 6010 \\
\text { EPA } 6010\end{array}$ & $3 / 4 / 99$ & $3 / 5 / 99$ & $3 / 7 / 99$ \\
\hline Chromings & ND & $0.01 \mathrm{mg} / \mathrm{L}$ & 1 & $\begin{array}{l}\text { EPA } 6010 \\
\text { EPA } 6010\end{array}$ & $3 / 499$ & $3 / 5 / 99$ & $3 / 7 / 99$ \\
\hline Laed & ND & $0.05 \mathrm{me} / \mathrm{L}$ & 1 & EPA 6010 & $3 / 4 / 99$ & $3 / 5 / 99$ & $3 / 7 / 99$ \\
\hline Mereary & ND & $0.002 \mathrm{mo} / \mathrm{L}$ & 10 & EPA 7470A & $3 / 499$ & $3 / 5 / 99$ & $3 / 7 / 99$ \\
\hline Seleswiven & ND & $0.1 \mathrm{men}$ & 1 & $\begin{array}{l}\text { EPA 7470A } \\
\text { EPA } 6010\end{array}$ & $3 / 499$ & $3 / 5 / 99$ & $3 / 5 / 99$ \\
\hline Silver & ND & $0.02 \mathrm{me} / 2$ & 1 & EPA 6010 & $\begin{array}{l}3 / 499 \\
3 / 4999\end{array}$ & $\begin{array}{l}3 / 5 / 99 \\
3 / 5 / 99\end{array}$ & $\begin{array}{l}3 / 7 / 99 \\
3 / 7 / 99\end{array}$ \\
\hline
\end{tabular}

F. - Dimuion Pacmer

J-Not Deceated

is report shall not be reproduced except in full, without the writuen approval of the laboratory. 


\begin{tabular}{|c|c|c|}
\hline $\begin{array}{l}\text { CLIINT: } \\
\text { PROJECT D: } \\
\text { PROJECT \#: }\end{array}$ & $\begin{array}{l}\text { Bechtel Nevids } \\
\text { V588/17777 } \\
17777\end{array}$ & $\begin{array}{l}\text { CLIENT D: } \quad \text { U-2bV GP-W7 } \\
\text { DATE SAMPLED: 2/24/99 } \\
\text { NEL SAMPLE DD: } 29903009-17\end{array}$ \\
\hline $\begin{array}{l}\text { TEST: } \\
\text { MATRDX: }\end{array}$ & $\begin{array}{l}\text { TCLP-8 Metals } \\
\text { Solid }\end{array}$ & \\
\hline
\end{tabular}

\begin{tabular}{|c|c|c|c|c|c|c|c|}
\hline PARAMIMTER & $\begin{array}{l}\text { RaYLT } \\
\text { me } 2\end{array}$ & $\begin{array}{l}\text { RMPORTING } \\
\text { LMII } \\
\end{array}$ & D. $\mathbf{P}$ & METEOD & $\begin{array}{c}\text { TCLPATLC } \\
\text { EXIRACIION } \\
\text { DATI } \\
\end{array}$ & DIGISTID & ANALYZOD \\
\hline & $\begin{array}{l}\mathrm{ND} \\
\mathrm{ND}\end{array}$ & $0.1 \operatorname{men} 2$ & 1 & EPA 6010 & $3 / 4 / 99$ & $3 / 5 / 99$ & $3 / 7 / 99$ \\
\hline Cadeninea & ND & $\begin{array}{r}1 . \mathrm{med} / \mathrm{L} \\
0.01 \mathrm{men} / \mathrm{L}\end{array}$ & 1 & $\begin{array}{l}\text { EPA } 6010 \\
\text { EPA } 6010\end{array}$ & $3 / 4 / 99$ & $3 / 5 / 99$ & $3 / 7 / 99$ \\
\hline Chromines & ND & $0.01 \mathrm{mr} /$ & 1 & $\begin{array}{l}\text { EPA } 6010 \\
\text { EPA } 6010\end{array}$ & $3 / 499$ & $3 / 5 / 99$ & $3 / 7199$ \\
\hline Lead & ND & $0.05 \mathrm{~mol}$ & 1 & EPA 6010 & $\begin{array}{l}3 / 4 / 99 \\
3 / 4 / 99\end{array}$ & 3/5/99 & $3 / 7 / 99$ \\
\hline Merony & ND & $0.002 \operatorname{mos} L$ & 10 & EPA 7470A & $\begin{array}{l}3 / 4 / 99 \\
3 / 4 / 99\end{array}$ & $3 / 5 / 99$ & $3 / 7 / 99$ \\
\hline Solenium & ND & $0.1 \mathrm{me} / \mathrm{L}$ & 1 & EPA 6010 & $\begin{array}{l}3 / 4 / 99 \\
3 / 400\end{array}$ & $3 / 5 / 99$ & $3 / 5 / 99$ \\
\hline Silver & ND & $0.02 \mathrm{~mol}$ & 1 & EPA 6010 & $\begin{array}{l}3 / 4 / 99 \\
3 / 4 / 99\end{array}$ & $\begin{array}{l}3 / 5 / 99 \\
3 / 5 / 99\end{array}$ & $\begin{array}{l}3 / 7 / 99 \\
3 / 7 / 99\end{array}$ \\
\hline
\end{tabular}


IIENT: Bechtel Nerada

PROJECT ID: V588/17777

?ROJECT \#: - 17777
CLIENT D: U-2bv GP-W10

DATE SAMPLED: 2/2499

NEL SAMPLE ID: .L9903009-18

IEST: TCLP-3 Metals

MATRD: Solid

\begin{tabular}{|c|c|c|c|c|c|c|c|}
\hline PARAMTEIXR & $\begin{array}{l}\text { EISTLT } \\
\text { mgL } \\
\end{array}$ & $\begin{array}{c}\text { axpORTLNG } \\
\text { InNIX }\end{array}$ & D. $\mathrm{E}$. & MEIFOD & $\begin{array}{c}\text { TCLPSTLC } \\
\text { EXTYMCTON } \\
\text { DATE }\end{array}$ & DIGESTMD & ANALYZAXD \\
\hline Anowie & ND & $0.1 \mathrm{~m} / \mathrm{L}$ & $\mathbf{l}$ & EPA 6010 & 3/4/99 & $3 / 5 / 99$ & $3 / 799$ \\
\hline 3arium & ND & $1 . \operatorname{mon}$ & 1 & EPA 6010 & $3 / 4 / 99$ & $3 / 5 / 99$ & $3 / 7 / 99$ \\
\hline Sudanionom & ND & $0.01 \mathrm{mel}$ & 1 & EPA 6010 & $3 / 4 / 99$ & $3 / 5 / 99$ & $3 / 7 / 99$ \\
\hline Jhroming & ND & $0.01 \mathrm{ma}$ & 1 & EPA 6010 & $3 / 4 / 99$ & $3 / 5 / 99$ & $3 / 7 / 99$ \\
\hline Lend & ND & $0.05 \mathrm{~m} / \mathrm{L}$ & 1 & EPA 6010 & $3 / 4 / 99$ & $3 / 5 / 99$ & $3 / 7 / 99$ \\
\hline Mareiry & ND & $0.002 \mathrm{mel}$ & 10 & EPA 7470A & $3 / 4 / 99$ & $3 / 5 / 99$ & $3 / 5 / 99$ \\
\hline Solonimen & ND & $0.1 \mathrm{~m} g /$ & 1 & EPA 6010 & $3 / 4 / 99$ & $3 / 5 / 99$ & $3 / 7 / 99$ \\
\hline silwor & ND & $0.02 \mathrm{me} / \mathrm{L}$ & 1 & EPA 6010 & 3/4/99 & $3 / 5 / 99$ & $3 / 7 / 99$ \\
\hline
\end{tabular}

2.F. - Dilution Factors

ID - Not Detected

This report shall not be reproduced except in full. without the written opproval of the laboratory. 
NEL LABORATORIES

\begin{tabular}{|c|c|c|}
\hline $\begin{array}{l}\text { CLIENT: } \\
\text { PROJECT D: } \\
\text { PROJECT H: }\end{array}$ & $\begin{array}{l}\text { Bechrel Nevadh } \\
\text { V588/17777 } \\
17777\end{array}$ & $\begin{array}{l}\text { CINNT I: } \quad \text { O-2bN GP-S1 } \\
\text { DATE SAMPLED: } 2 / 24 / 99 \\
\text { NEI SAMPLE ID: L9903009-19 }\end{array}$ \\
\hline $\begin{array}{l}\text { TEST: } \\
\text { MATRDX: }\end{array}$ & $\begin{array}{l}\text { TCLP\&B Metals } \\
\text { Solid. }\end{array}$ & \\
\hline
\end{tabular}

\begin{tabular}{|c|c|c|c|c|c|c|c|}
\hline PAPAMTITER & $\begin{array}{l}\text { RXSULT } \\
\text { melL }\end{array}$ & $\begin{array}{c}\text { BrponTING } \\
\text { LMax }\end{array}$ & D. F. & METPOOD & $\begin{array}{c}\text { TCLPSTLC } \\
\text { DXIRACIION } \\
\text { DATL } \\
\end{array}$ & DIGXSTID & ANALYZADD \\
\hline $\begin{array}{l}\text { Ardonic } \\
\text { Beniven }\end{array}$ & $\begin{array}{l}\text { ND } \\
\text { ND }\end{array}$ & $0.1 \mathrm{mel}$ & 1 & EPA 6010 & $3 / 499$ & $3 / 5 / 99$ & $3 / 7 / 99$ \\
\hline Cadanionen & $\begin{array}{l}\text { ND } \\
\text { ND }\end{array}$ & 1. $m g /$ & 1 & EPA 6010 & $3 / 4 / 99$ & $3 / 5 / 99$ & $3 / 7 / 99$ \\
\hline Chrominum & ND & $\begin{array}{l}0.01 \mathrm{~m} / \mathrm{L} \\
0.01 \mathrm{mg} / 2\end{array}$ & 1 & EPA 6010 & $3 / 4 / 99$ & $3 / 5 / 99$ & $3 / 7 / 99$ \\
\hline Load. & ND & $\begin{array}{l}0.01 \mathrm{mg} / \\
0.05 \mathrm{mg} /\end{array}$ & 1 & EPA 6010 & $3 / 4 / 99$ & $3 / 5 / 99$ & $3 / 7 / 99$ \\
\hline Mereary & ND & $\begin{array}{l}0.05 \mathrm{me} / \mathrm{L} \\
0.002 \mathrm{mog} /\end{array}$ & 1 & EPA 6010 & $3 / 4 / 99$ & $3 / 5 / 99$ & $3 / 7 / 99$ \\
\hline Selesinim & $\mathbf{N D}$ & $\begin{array}{r}0.002 \mathrm{med} \\
0.1 \mathrm{mg} \alpha\end{array}$ & 10 & EPA 7470A & $3 / 4 / 99$ & $3 / 5 / 99$ & $3 / 5 / 99$ \\
\hline Silver & ND & $0.02 \mathrm{me} / 2$ & $\begin{array}{l}1 \\
1\end{array}$ & $\begin{array}{l}\text { EPA } 6010 \\
\text { EPA } 6010\end{array}$ & $\begin{array}{l}3 / 4 / 99 \\
3 / 4 / 99\end{array}$ & $\begin{array}{l}3 / 5 / 99 \\
3 / 5 / 99\end{array}$ & $3 / 7 / 99$ \\
\hline
\end{tabular}

F. - Dilution Factor

) - Not Detected

is report shall not be reproduced exeept in full, without the wrinen approval of the laboratory. 


\section{CIIENT: Bechel Nevada}

PROJECT D: VS8\&17777

PROJECT\#: 17777

\section{TEST: TCR-8Metils \\ MATRX: Solid}

\section{CLIENT ID: U-26v GPSS}

DATE SAMPLED: 224/99

NEI SAMPLE ID: L9903009-20

\begin{tabular}{|c|c|c|c|c|c|c|c|}
\hline PARAMEIXR & $\begin{array}{l}\text { Prout } \\
\text { mot }\end{array}$ & $\begin{array}{l}\text { PAPORIING } \\
\text { INTI }\end{array}$ & D. . & MTIROD & $\begin{array}{l}\text { TCLPSTLC } \\
\text { IOTRCTON } \\
\text { DATS }\end{array}$ & DIGXXYMD & ANA GYTANO \\
\hline $\begin{array}{l}\text { Assomic } \\
\text { Barrom }\end{array}$ & No & $0.1 \mathrm{~m} / \mathrm{L}$ & 1 & EPA 6010 & $3 / 499$ & $3 / 5 / 99$ & $3 / 7 / 99$ \\
\hline Cadomions & ND & $\begin{array}{l}1 . \mathrm{mg} \Omega \\
0.01 \mathrm{~m} / \Omega\end{array}$ & 1 & EPA 6010 & $3 / 4199$ & $3 / 5 / 99$ & $3 / 7 / 99$ \\
\hline Chromiuns & $\mathrm{ND}$ & $0.01 \mathrm{mo} / \mathrm{L}$ & 1 & ERA 6010 & $3 / 4 / 99$ & $3 / 5 / 99$ & $3 / 7 / 99$ \\
\hline Land & ND & $0.05 \mathrm{~mol}$ & 1 & $\begin{array}{l}\text { DPA } 6010 \\
\text { EPA } 6010\end{array}$ & $3 / 499$ & $3 / 5 / 99$ & $3 / 7199$ \\
\hline Meresy & ND & $0.002 \mathrm{men} /$ & 10 & $\begin{array}{l}\operatorname{EPA} 6010 \\
\text { EPA 7470A }\end{array}$ & $3 / 4199$ & $3 / 5 / 99$ & $3 / 7 / 99$ \\
\hline Solenines & ND & $0.1 \operatorname{mog} 2$ & 1 & BPA 6010 & $3 / 4 / 99$ & 3/5/99 & $3 / 5 / 99$ \\
\hline Silver & ND & $0.02 \mathrm{mo} / \mathrm{L}$ & 1 & EPA 6010 & $\begin{array}{l}3 / 4 / 99 \\
3 / 4 / 99\end{array}$ & $\begin{array}{l}3 / 5 / 99 \\
3 / 5 / 99\end{array}$ & $\begin{array}{l}3 / 7 / 99 \\
37700\end{array}$ \\
\hline
\end{tabular}

F. - Dimrion Factor

D - Not Detweted

is reporr shall not be reproduced exeept in full, without the whtten approval of the laboratory. 


\section{NEL LABORATORIES}

\begin{tabular}{|c|c|c|}
\hline $\begin{array}{l}\text { CIDNT: } \\
\text { PROJECT ID: } \\
\text { PROJECT \#: }\end{array}$ & $\begin{array}{l}\text { Bechtel Nevada } \\
\text { Vs88/17777 } \\
17777\end{array}$ & $\begin{array}{ll}\text { CLIENT D: } & \text { D-26/ CP-S7 } \\
\text { DATE SAMPLED: 2/24/99 } \\
\text { NEL SAMPLE D: L L903009-21 }\end{array}$ \\
\hline $\begin{array}{l}\text { TEST: } \\
\text { MAIRIX: }\end{array}$ & $\begin{array}{l}\text { TCLP-8 Metals } \\
\text { Solid }\end{array}$ & \\
\hline
\end{tabular}

\begin{tabular}{|c|c|c|c|c|c|c|c|}
\hline PARAMIMIR & $\begin{array}{c}\text { RESULT } \\
\text { mo/L }\end{array}$ & $\begin{array}{c}\text { REPORTING } \\
\text { IMUI }\end{array}$ & D. $F$. & METIOD & $\begin{array}{l}\text { TCLPATLC } \\
\text { DXIRACIION } \\
\text { DATI } \\
\end{array}$ & DIGISIED & ANALYZaXD \\
\hline $\begin{array}{l}\text { Anemie } \\
\text { Berinim }\end{array}$ & $\begin{array}{l}\text { DN } \\
\text { D }\end{array}$ & 0.1 men $\pi$ & 1 & EPA 6010 & $3 / 4 / 99$ & $3 / 5 / 99$ & $3 / 7 / 99$ \\
\hline Cadanimen & ND & $\begin{array}{l}1 . m / 2 \\
0.01 \operatorname{mog} 2\end{array}$ & 1 & EPA 6010 & $3 / 4 / 99$ & $3 / 5 / 99$ & $3 / 7 / 99$ \\
\hline Chrominem & ND & $0.01 \mathrm{mo} /$ & 1 & $\begin{array}{l}\text { EPA } 6010 \\
\text { EPA } 6010\end{array}$ & 3/4/99 & $3 / 5 / 99$ & $3 / 7 / 99$ \\
\hline Lead & ND & $0.05 \mathrm{mo/L}$ & 1 & EPA 6010 & $3 / 499$ & $3 / 5 / 99$ & $3 / 7 / 99$ \\
\hline Meroury & 0.0028 & $0.002 \mathrm{mog} / \mathrm{L}$ & 10 & EPA 7470A & $3 / 4 / 99$ & $3 / 5 / 99$ & $3 / 7 / 99$ \\
\hline Solominen & ND & 0.1 mel & 1 & EPA 6010 & 3/4/99 & $3 / 5 / 99$ & $3 / 5 / 99$ \\
\hline Silver & ND & $0.02 \mathrm{mg} /$ & 1 & EPA 6010 & $3 / 4 / 99$ & $315 / 99$ & $3 / 7 / 99$ \\
\hline
\end{tabular}

F. - Dibution Factor

)- Not Detected

s report shall not be reproduced except in fill, without the written approval of the laboratory. 


\section{CLDarT: Bechrel Nevada \\ PROJECT D: VS88/1777 \\ PROJECI *: 17777}

\section{TEST:}

MATRDX:

\section{TCLP-8 Metals}

Solid
CIINT D:

DATE SAMPLED: 2/2499

NEL SAMPLE D: L9903002-22

\section{RARAMITIAR}

Aranis

Borive

Cadorion

Chrominen

Lead

Mereny

Solmaidion

Silvar

\begin{tabular}{|c|c|c|c|}
\hline $\begin{array}{l}\text { RouLt } \\
\text { nod }\end{array}$ & $\begin{array}{c}\text { Drporaxe } \\
\text { InIT }\end{array}$ & B. 8 & MUTEOP \\
\hline No & $0.1=\Omega$ & 1 & EPA 6010 \\
\hline N & $1 . \mathrm{m} / \mathrm{L}$ & 1 & DPA 6010 \\
\hline ND & $0.01 \mathrm{mel}$ & 1 & EPA c010 \\
\hline ND & $0.01 \mathrm{~m} \cdot \mathrm{L}$ & 1 & EPA 6010 \\
\hline ND & $0.05 \mathrm{me} /$ & 1 & EPA 6010 \\
\hline ND & $0.002 \mathrm{ex} / \mathrm{L}$ & 10 & EPA 7470A \\
\hline ND & $0.1 \mathrm{~m} / \Omega$ & 1 & BPA 6010 \\
\hline $\mathbf{N D}$ & $0.02 \mathrm{~m} / \mathrm{L}$ & 1 & EPA 6010 \\
\hline
\end{tabular}

TALPIIC

manactron

DATE DIGESTED ANAIYZAMD

$3 / 4 / 99$

$3 / 4199$

$3 / 4 / 99$

$3 / 4 / 99$

$3 / 499$

$3 / 4 / 99$

$3 / 4199$

$3 / 4 / 99$
$3 / 5 / 99$

$3 / 5 / 99$

$3 / 5199$

$3 / 5 / 99$

$3 / 5199$

$3 / 5 / 99$

$3 / 5 / 99$

$3 / 5 / 99$
$3 / 799$

37799

$3 / 7199$

377199

37799

$3 / 5 / 99$

$3 / 799$.

$3 / 799$

F. - Dilution Fretor

\section{J) -Not Detected}

is report shall not be reproduced accept in full, withour the whituen approval of the laboratong 
NEL LABORATORIES

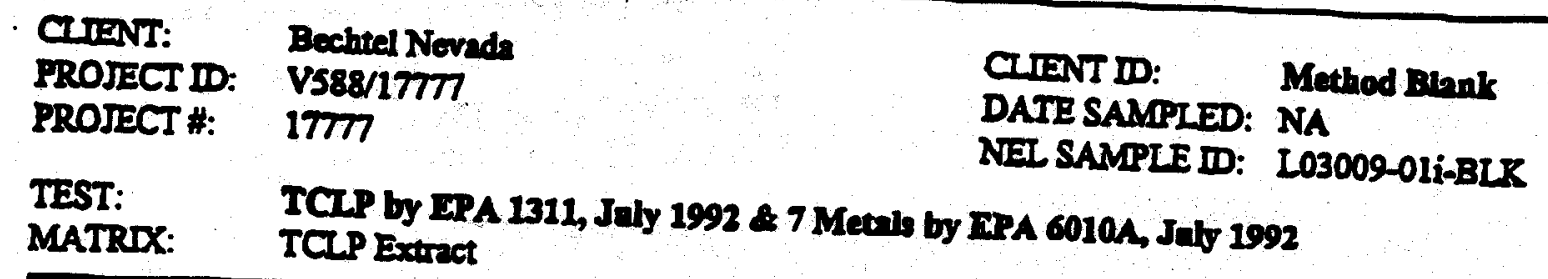

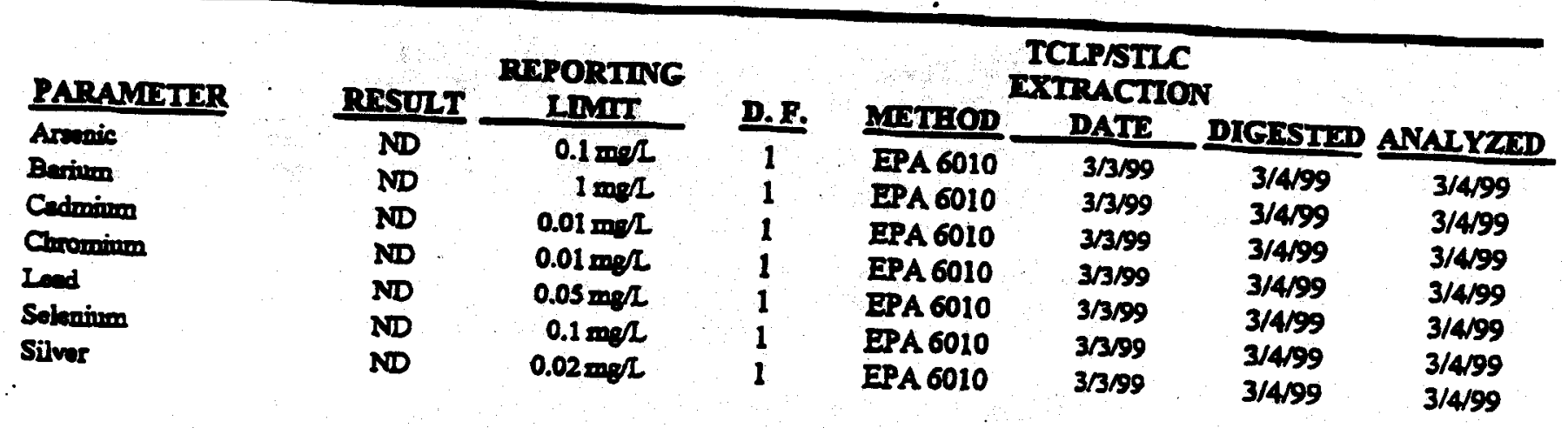

\section{J.F. - Dilucion Factor \\ ND - Not Dewected}

his report shall not be reproduced except in full, without the written approval of the laboratory. 


\section{NEL LABORATORIES}

\begin{tabular}{|c|c|}
\hline $\begin{array}{l}\text { LIDNT: } \\
\text { ROJECT D: } \\
\text { DOJSCT \#: }\end{array}$ & $\begin{array}{l}\text { Bechtel Nevada } \\
\text { VS88/17777 } \\
17777\end{array}$ \\
\hline
\end{tabular}

CLIENT D: Method Blink

DATE SAMPLED: NA

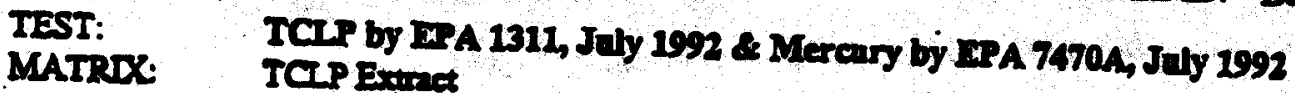

NEL SAMPLE ID: L03009-15FE-BLK

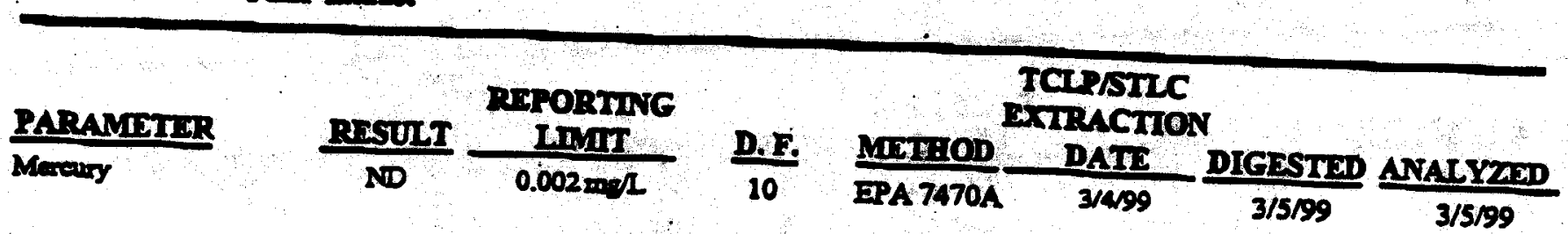

D.F. - Dilmion Factor

VD - Nor Devected

This report sthall not be reproduced except in full, wilhout she writien agproval of the laboratory. 
CIIINT: Bechal Nevada

FROJECT D: Vs88/17777

- PROJECT \#: 1777
CLIENT D: Method Bank

DATE SAMPLED: NA

NEL SAMPLE DD: L03009-15i-BLK

TEST:

MATRDX:

TCLP by EPA 1311, Jaly 1992 \& 7 Metals by XPA 6010A, July 1992

\begin{tabular}{|c|c|c|c|c|c|c|c|}
\hline$\frac{\text { PARAMITIMR }}{\text { Aremie }}$ & BNoLT & $\begin{array}{l}\text { PrPonTING } \\
\text { InMax }\end{array}$ & D. F. & Marrion & $\begin{array}{l}\text { TCRPATL } \\
\text { DXIRACIION } \\
\text { DATE }\end{array}$ & DrGXSYX & \\
\hline 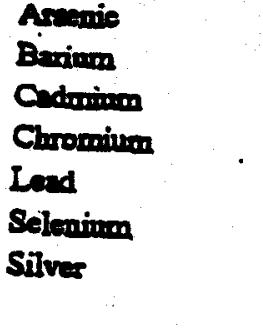 & $\begin{array}{l}N D \\
N D \\
N D \\
N D \\
N D \\
N D\end{array}$ & $\begin{array}{c}0.1 \mathrm{me} / \\
1 \mathrm{me} / \\
0.01 \mathrm{me} / \\
0.01 \mathrm{me} / \\
0.05 \mathrm{med} \\
0.1 \mathrm{me} / \\
0.02 \mathrm{me} /\end{array}$ & $\begin{array}{l}1 \\
1 \\
1 \\
1 \\
1 \\
1 \\
1\end{array}$ & $\begin{array}{l}\text { EPA } 6010 \\
\text { EPA } 6010 \\
\text { EPA } 6010 \\
\text { EPA } 6010 \\
\text { EPA } 6010 \\
\text { EPA } 6010 \\
\text { EPA } 6010\end{array}$ & $\begin{array}{l}3 / 1 / 4 \\
3 / 499 \\
3 / 499 \\
3 / 4199 \\
3 / 4199 \\
3 / 4199 \\
3 / 4199 \\
3 / 4 / 99\end{array}$ & $\begin{array}{c}016 \text { J } 1 / x_{0} \\
3 / 5 / 99 \\
3 / 5 / 99 \\
3 / 5 / 99 \\
3 / 5 / 99 \\
3 / 5 / 99 \\
3 / 5 / 99 \\
3 / 5 / 99\end{array}$ & $\begin{array}{c}\text { DNALYZAOD } \\
3 / 7 / 99 \\
3 / 7 / 99 \\
3 / 7 / 99 \\
3 / 7 / 99 \\
3 / 7 / 99 \\
3 / 7 / 99 \\
3 / 7 / 99\end{array}$ \\
\hline
\end{tabular}

F. - Dihution Pactor

D - Not Detected

is report shall not be reproduced except in full, withous the written approval of the laboracon. 


\begin{tabular}{|c|c|c|c|}
\hline $\begin{array}{l}\text { CLIENT: } \\
\text { PROJECT D: } \\
\text { PROJECT \#: }\end{array}$ & $\begin{array}{l}\text { Bechud Nevode } \\
\text { V588/1777 } \\
17777\end{array}$ & $\begin{array}{l}\text { CLIENT D: } \\
\text { DATE SAMLLED: } \\
\text { NEL SAMPLE ID: }\end{array}$ & $\begin{array}{l}\text { Method Bhink } \\
\text { NA } \\
\text { L03009-IFF-BLX }\end{array}$ \\
\hline
\end{tabular}

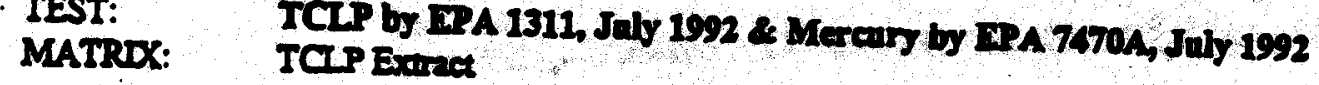

\begin{tabular}{|c|c|c|c|c|c|}
\hline PARAMEYIXS & RSOLx & 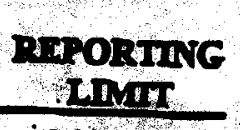 & D.E. & 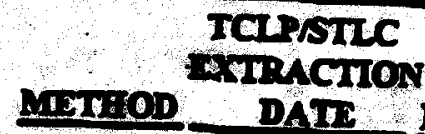 & DIGXSTOXD ANATYOM \\
\hline exoury & 10 & $0.002 \mathrm{~m} / 2$ & 10 & EPA 7470A 3/3/90 & $3 / 499 \quad \frac{1600}{31400}$ \\
\hline
\end{tabular}

D.R. - Dimion Factor

ND. Nor Detected

This report shall not be reproduced except in full, without the writuen approval of the laboratory. 


\section{CIIENT: Bechtel Nevada}

P.O. Box 98521, M/S NTS273

Las Vegas, NV 89193-8521

AIIN: Ted Redding

PROJECT NAME: V588

PROJECT NUMBER: $17 T 77$

NEL ORDER ID: 29903009

Arnched are the amalytical results for samples in support of the above referenced project.

Samples were received by NEI in good condition, under chain of custody on 3/1/99.

Samples were analyzed as received.

Should you have any questions or comments, please feel free to contact our Client Services deparment at (702)
657-1010.

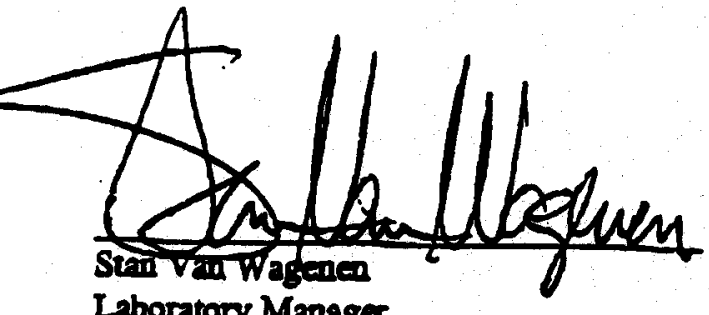

Laboratory Mmager

\section{CERTIFLCATIONS:}

Arizona

Califormia

US Anomy Corps

of Enginears

\begin{tabular}{lll} 
Reno & Las Veens & S. Califomia \\
\hline AZ0520 & AZ0518 & AZ0583 \\
1707 & 2002 & 2264
\end{tabular}

Certified Cercified Certified

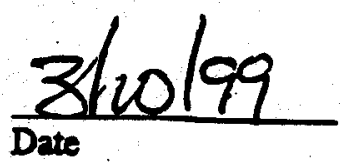

Reno Idaho Certified Montana Certified Nevada NV033 L.ACS.D. 


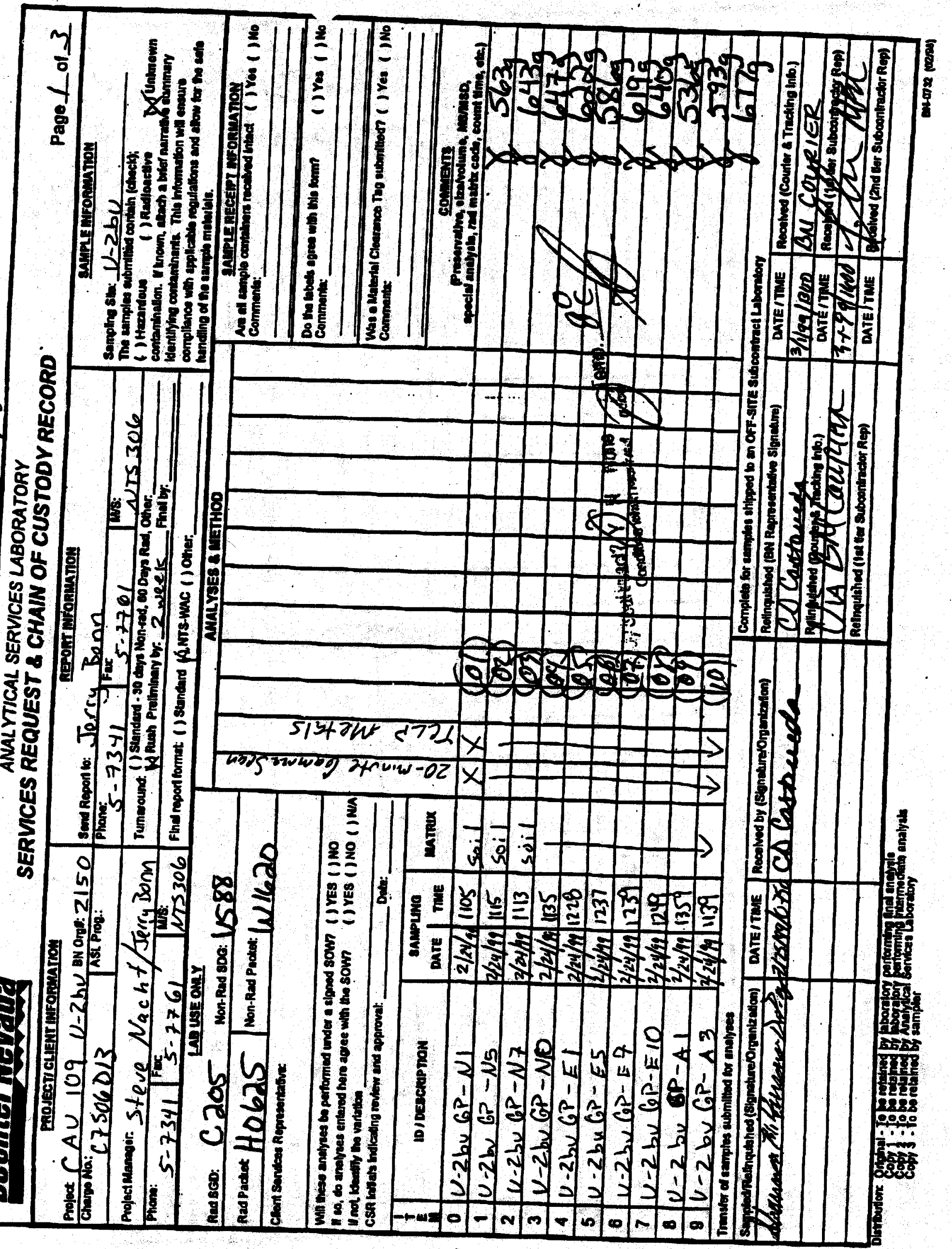




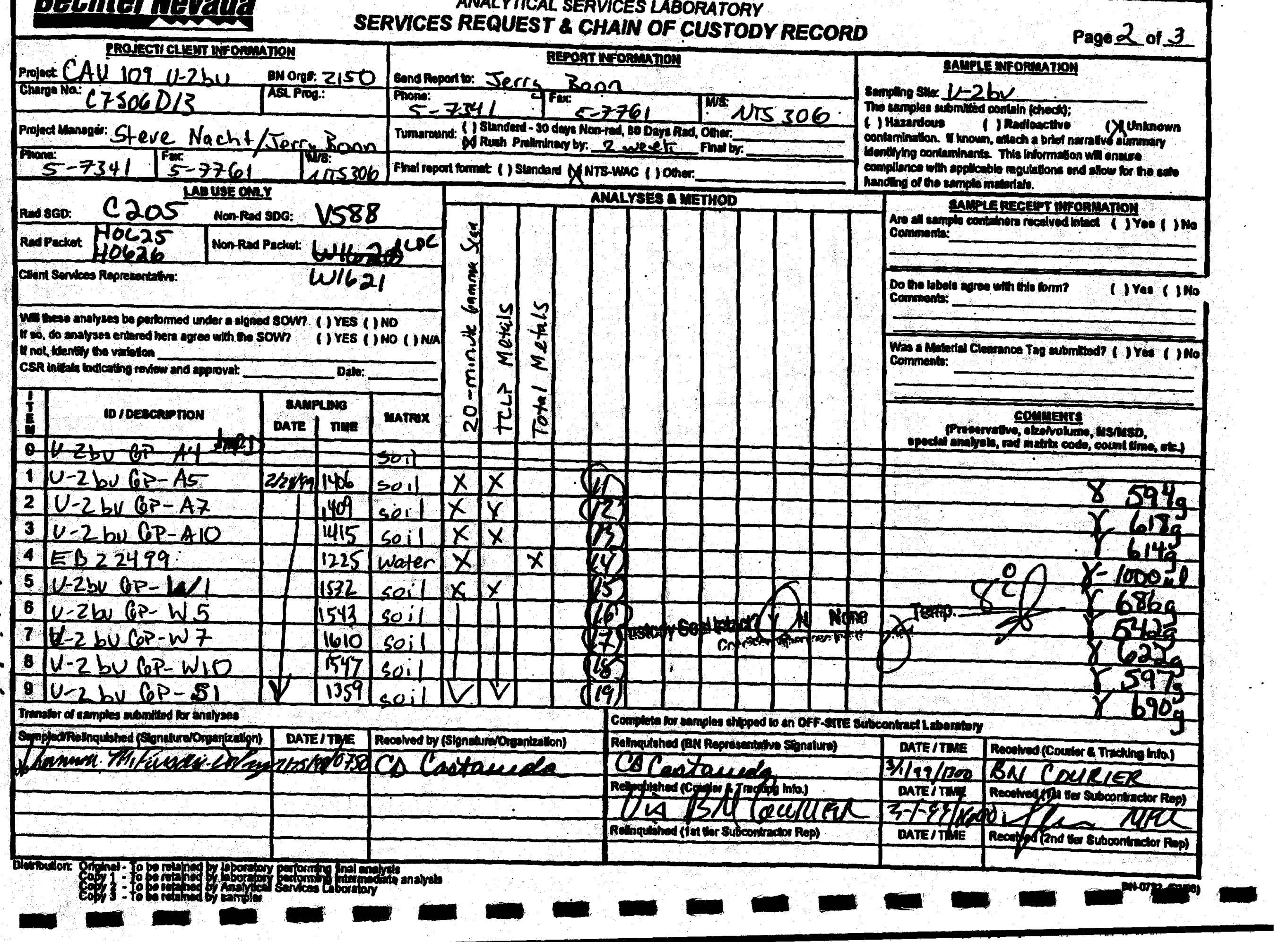




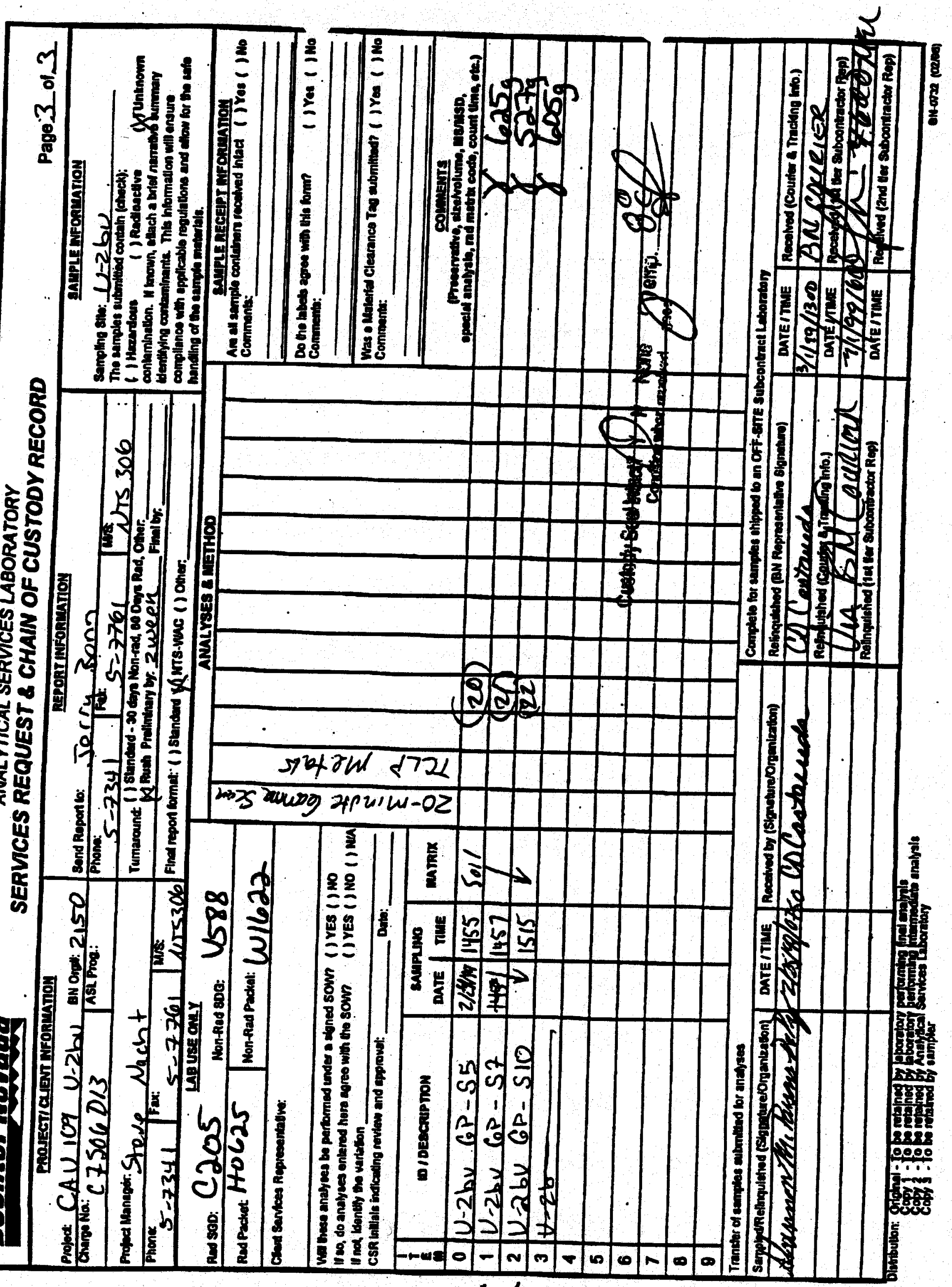




\section{RADIOMETRIC DATA ANALYSIS PACKAGE}

BECHTEL NEVADA Analytical Services

Method Type: RAGMA
Case No.: U-2bu Subsidence Crater

SDG No.: C205

Sample Numbers

\begin{tabular}{|c|c|}
\hline DOE No. & Lab ID No. \\
\hline EB 2-24-99 & H0626-0-75327 \\
\hline U2bu GP-A1 & HO625-8-75314 \\
\hline U2bu GP-A3 & Ho625-9-75315 \\
\hline U2bu GP-A5 & H0625-A-75316 \\
\hline U2bu GP-EI & $H 0625-4-75310$ \\
\hline U2bu GP-E10 & Ho625-7-75313 \\
\hline U2bu GP-ES & H0625-5-75311 \\
\hline U2bu GP-E7 & H0625-6-75312 \\
\hline U2bu GP-N1 & H0625-0-75297 \\
\hline U2bu GP-N10 & HO625-3-75300 \\
\hline U2bu GP-N5 & HO625-1-75298 \\
\hline U2bu GP-N7 & H0625-2-75299 \\
\hline U2bu GP-A10 & H0625-C.75318 \\
\hline U2bu GP-A7 & H0625-8-75317 \\
\hline U2bu GP.S1 & H0625-H-75323 \\
\hline
\end{tabular}

DOE No.

U2bu GP-S10

U2bu GP-S5

U2bu GP-S7

U2bu GP.W1

U2bu GP-W10

U2bu GP-W5

U2bu GP-W7
Lab 10 No. H0625-K-75326 H0625-1-75324

H0625-J-75325

HO625-D-75319

H0625-G-75322

HO625-E-75320

H0625-F-75321

Comments: Data generated from the gamma spectroscopy analyses of soil samples submitted to the laboratory on $2 / 25 / 99$.

Release of the data contained in this data package has been authorized by the Laboratory Manager or the Manager's designee, as verified by the following signature:

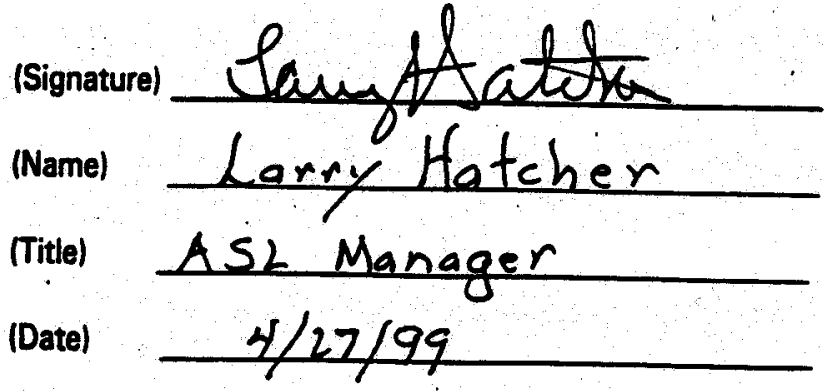




\begin{tabular}{|c|c|c|c|c|c|c|c|c|c|c|}
\hline Doe $\ldots . . . .$. Sample No. ...... & $\begin{array}{l}\text { Sample } \\
\text { Type }\end{array}$ & $\begin{array}{l}\text { Radio- } \\
\text { nuclide }\end{array}$ & Result & $\begin{array}{l}\text { Uncer- } \\
\text { tainty }\end{array}$ & $\begin{array}{l}\text { Result } \\
\text { Units }\end{array}$ & $\begin{array}{c}\text { Analysis } \\
\text { Date }\end{array}$ & $\begin{array}{l}\text { Semple } \\
\text { Matrix }\end{array}$ & $\begin{array}{l}\text { Sample } \\
\text { Size }\end{array}$ & Method No. & Instrument ID \\
\hline EB 2-24.99 & REG & No Nucl Det & $0.00 E+00$ & $0.0 E+\infty$ & pCilkg & $02 \cdot 25-99$ & WATER & $500.00 \mathrm{ml}$ & E10.602.PC & 06-01 \\
\hline EB 2-24-99 & REG & U 238 & $0.00 E+\infty 0$ & $0.0 E+\infty 0$ & pCilkg & $02-25-99$ & WATER & $500.00 \mathrm{ml}$ & E10.602.PC & 06.01 \\
\hline EB 2-24.99 & REG & AM241 & $0.00 E+\infty 0$ & $0.0 E+\infty$ & pCinkg & $02-25-99$ & WATER & $500.00 \mathrm{ml}$ & E10.602.PC & $06-01$ \\
\hline U2bu GP-A1 & REG & C060 & $5.13 E+03$ & $7.9 E+02$ & pCilkg & 02-25-99 & soll & $593.00 \mathrm{gm}$ & E10.602.PC & $05-01$ \\
\hline U2bu GP-A1 & REG & CS137 & $5.78 E+02$ & $2.0 E+02$ & pCi/kg & $02-25-99$ & soll. & $593.00 \mathrm{gm}$ & E10.602.PC & $05-01$ \\
\hline U2bu GP-A1 & REG & $K 40$ & $2.46 E+04$ & $4.8 E+03$ & pCikg & 02-25-99 & SOIL & $593.00 \mathrm{gm}$ & E10.602.PC & 05-01 \\
\hline U2bu GP-A1 & REG & RA226 & $1.58 E+03$ & $4.2 E+02$ & pCi/kg & 02-25-99 & soll. & $593.00 \mathrm{gm}$ & E10.602.PC & $05-01$ \\
\hline U2bu GP.A1 & AEG & TH228 & $2.05 E+03$ & $4.6 E+02$ & pCi/kg & 02-25-99 & soll & $593.00 \mathrm{gm}$ & E10.602.PC & 05-01 \\
\hline U2bu GP-A1 & REG & U 238 & $0.00 E+00$ & $0.0 E+00$ & pCi/kg & 02-25-99 & soll & $593.00 \mathrm{gm}$ & E10.602.PC & $05-01$ \\
\hline U2bu GP.A1 & AEG & AM241 & $0.00 E+00$ & $0.0 E+00$ & pCikg & 02-25-99 & soll & $593.00 \mathrm{gm}$ & E10.602.PC & $05-01$ \\
\hline U2bu GP-A3 & REG & $\mathrm{CO6O}$ & $1.13 E+03$ & $3.0 E+02$ & pCl/kg & 02-25-99 & solL & $677.00 \mathrm{gm}$ & E10.602.PC & 05.01 \\
\hline U2bu GP-A3 & REG & $K 40$ & $2.66 E+04$ & $5.0 E+03$ & pCing & 02-25-99 & soll & $677.00 \mathrm{gm}$ & E10.602.PC & 05.01 \\
\hline U2bu GP-A3 & REG & TH228 & $2.34 E+03$ & $4.6 E+02$ & PCi/kg & 02-25-99 & SOIL & $677.00 \mathrm{gm}$ & E10.602.PC & 05.01 \\
\hline U2bu GP-A3 & REG & U 238 & $0.00 E+00$ & $0.0 E+00$ & pCilkg & $02-25-99$ & SOIL & $677.00 \mathrm{gm}$ & E10.602.PC & $05-01$ \\
\hline U2bu GP-A3 & REG & AM241 & $0.00 E+00$ & $0.0 E+\infty$ & pCi/kg & 02-25-99 & SOIL & $677.00 \mathrm{gm}$ & Et0.602.PC & $05-01$ \\
\hline
\end{tabular}

- Comments: Data generated from the gamma spectroscopy analyses of soil samples submitted to the laboratory on $2 / 25 / 99$. 
RADIOMETRIC ANALYSIS RESULTS

BECHTEL Analytical Services Case No.: U-2bu Subsidence Crater

Method Type: RAGMA SDG No.: C205

\begin{tabular}{|c|c|c|c|c|c|c|c|c|c|c|}
\hline ....... Sample No. ...... & $\begin{array}{l}\text { Sample } \\
\text { Type }\end{array}$ & $\begin{array}{l}\text { Padto- } \\
\text { nuctide }\end{array}$ & Rosuch & $\begin{array}{l}\text { Uneir- } \\
\text { tainty }\end{array}$ & $\begin{array}{l}\text { Result } \\
\text { Unita }\end{array}$ & $\begin{array}{c}\text { Andints } \\
\text { Doto }\end{array}$ & $\begin{array}{l}\text { Semple } \\
\text { Motutx }\end{array}$ & $\begin{array}{l}\text { Semplo } \\
\text { Sezo }\end{array}$ & 'Menthod No. & Instrument D \\
\hline U2bou GP-A5 & REG & $\times 40$ & $2.62 E+04$ & $5.0 E+03$ & PCI/kg & $02-26-90$ & soln & $594.00 \mathrm{~cm}$ & E10.e02.PC & $05-01$ \\
\hline U2bu GP-A5 & REG & RA228 & $1.41 E+03$ & $3.7 E+02$ & parks & 02-25-89 & son. & $594.00 \mathrm{gm}$ & E10.c02.PC & 05-01 \\
\hline U2bu GP-A5 & REG & TH228 & $2.18 E+03$ & $4.2 E+02$ & pCrikg & $02-25-80$ & sole & $594.00 \mathrm{~cm}$ & E10.002.PC & $05-01$ \\
\hline U2tw GP-A5 & REG & U 238 & $0.00 E+\infty$ & $0.0 E+\infty$ & pcing & $02-25-60$ & son & $594.00 \mathrm{~cm}$ & E10.602.PC & $05-01$ \\
\hline UZWU EP-A5 & REG & AMR241 & $0.00 E+\infty$ & $0.0 E+\infty$ & pcikg & 02-25-80 & soln & $594.00 \mathrm{~cm}$ & E10.002.PC & $05-01$ \\
\hline UZWU GP-EI & REG & $\times 40$ & $2.38 E+04$ & $4.7 E+03$ & penkg. & $02-26-80$ & sol. & $586.00 \mathrm{gm}$ & E10.602.PC & 05-01 \\
\hline U2bu GP-EI & REG & TH228 & $6.34 E+04$ & $1.2 E+04$ & pCing & 02-25-80 & son & $586.00 \mathrm{~mm}$ & E10.002.PC & 05-01 \\
\hline U2bu CP-E1 & REG & U 238 & $0.00 E+\infty 0$ & $0.0 E+\infty$ & pelikg & 02-25-90 & soll & $588.00 \mathrm{gm}$ & E10.002.PC & $05-01$ \\
\hline U2bu GP-E1 & REG & AM241 & $0.00 E+\infty 0$ & $0.0 E+\infty$ & PCAko & 02-25-99 & soln & $580.00 \mathrm{~cm}$ & E10.002.PC & $05-01$ \\
\hline U2tWU GP-E10 & REG & $\times 40$ & $2.44 E+04$ & $4.8 E+03$ & pCing & 02-25-99 & sọk & $538.00 \mathrm{~cm}$ & E10.002.PC & $05-01$ \\
\hline U2tW GP-E10 & REG & TH228 & $2.18 E+03$ & $4.2 E+02$ & peing & 02-25-99 & soll & $538.00 \mathrm{~cm}$ & E10.602.PC & $05-01$ \\
\hline U2tW GP-E10 & REG & U 238 & $0.00 E+\infty$ & $0.0 E+\infty$ & pCing & 02-25-99 & soln & $538.00 \mathrm{gm}$ & E10.e02.PC & 05-01 \\
\hline U2bu GP-E10 & REO & AM241 & $0.00 E+\infty$ & $0.0 E+\infty$ & pCukg & 02-25-90 & son & $536.00 \mathrm{gm}$ & Et0.602.PC & $05-01$ \\
\hline U2bu GP-E5 & REG & $\times 40$ & $2.73 E+04$ & 5.1E+03 & pCing & 02-25-99 & soll & $619.00 \mathrm{~cm}$ & E10.602.PC & 05.01 \\
\hline U2bu GP-E5 & REG & $\operatorname{ma226}$ & $1.39 E+03$ & 3.7E+ 02 & pcing & 02-25-99 & solk & $619.00 \mathrm{~cm}$ & E10.802.PC & $05-01$ \\
\hline
\end{tabular}

- Comments: Date generated frpm the gamma spectroscopy analyses of soil semples submitted to the laboratory on 2/25/99. 


\section{BECHTEL Analytical Services}

Method Type: RAGMA
Case No.: U-2bu Subsidence Crater

SDG No.: C205

\begin{tabular}{|c|c|c|c|c|c|c|c|c|c|c|}
\hline ...... Sample No. ....... & $\begin{array}{l}\text { Sample } \\
\text { Type }\end{array}$ & $\begin{array}{l}\text { Radio- } \\
\text { nuclide }\end{array}$ & Result & $\begin{array}{l}\text { Uncer- } \\
\text { tainty }\end{array}$ & $\begin{array}{l}\text { Result } \\
\text { Units }\end{array}$ & $\begin{array}{l}\text { Analysis } \\
\text { Date }\end{array}$ & $\begin{array}{l}\text { Sample } \\
\text { Matrix }\end{array}$ & $\begin{array}{l}\text { Sample } \\
\text { Stze }\end{array}$ & Method No. & Instrument ID \\
\hline U2bu GP-E5 & REG & TH228 & $1.80 E+03$ & $3.8 E+02$ & pCing & $02-25-99$ & SOIL & $619.00 \mathrm{gm}$ & E10.602.PC & $05-01$ \\
\hline U2bu GP-E5 & REG & TH232 & $2.11 E+03$ & $8.4 E+02$ & pCikg & $02-25-99$ & SOIL & $619.00 \mathrm{gm}$ & E10.602.PC & $05-01$ \\
\hline U2bu GP-E5 & REG & U 238 & $0.00 E+00$ & $0.0 E+00$ & pCikg & $02-25-99$ & soll. & $619.00 \mathrm{gm}$ & E10.602.PC & $05-01$ \\
\hline U2bu GP-E5 & REG & AM241 & $0.00 E+00$ & $0.0 E+00$ & pCing & 02-25-99 & SOIL & $619.00 \mathrm{gm}$ & E10.602.PC & $05-01$ \\
\hline U2bu GP-E7 & REG & $K 40$ & $2.45 E+04$ & $4.7 E+03$ & pCing & 02-25-99 & SOHL & $640.00 \mathrm{gm}$ & E10.602.PC & $05-01$ \\
\hline U2bu GP-E7 & REG & TH228 & $1.97 E+03$ & $4.0 E+02$ & pCing & 02-25-99 & SOIL. & $640.00 \mathrm{gm}$ & E10.602.PC & $05-01$ \\
\hline U2bu GP-E7 & REG & U 238 & $0.00 E+00$ & $0.0 E+00$ & pCikg & 02-25.99 & SOIL & $640.00 \mathrm{gm}$ & E10.602.PC & $05-01$ \\
\hline U2bu GP-E7 & REG & AM241 & $0.00 E+00$ & $0.0 E+\infty 0$ & pCing & $02-25-99$ & soll. & $640.00 \mathrm{gm}$ & E10.602.PC & 05.01 \\
\hline U2bu GP-N1 & REG & CO60 & $1.42 E+03$ & $3.4 E+02$ & pCing & 02-25-99 & soll & $563.00 \mathrm{gm}$ & E10.602.PC & 05-01 \\
\hline U2bu GP.N1 & REG & CS137 & $2.78 E+02$ & $1.3 E+02$ & pCi/kg & 02-25-99 & soll. & $563.00 \mathrm{gm}$ & E10.602.PC & 05-01 \\
\hline U2bu GP-N1 & REG & $K 40$ & $2.49 E+04$ & $4.8 E+03$ & $\mathrm{pCi} / \mathrm{kg}$ & $02-25-99$ & SOIL & $563.00 \mathrm{gm}$ & E10.602.PC & $05-01$ \\
\hline U2bu GP.N1 & REG & $\mathrm{TH} 228$ & $2.49 E+03$ & $4.7 E+02$ & pCI/kg & 02-25-99 & soll- & $563.00 \mathrm{gm}$ & E10.602.PC & $05-01$ \\
\hline U2bu GP-N1 & REG & U 238 & $0.00 E+00$ & $0.0 E+00$ & pCi/kg & 02-25-99 & soll & $563.00 \mathrm{gm}$ & E10.602.PC & $05-01$ \\
\hline U2bu GP-N1 & REG & AM241 & $0.00 E+00$ & $0.0 E+00$ & pCikg & 02-25-99 & SOIL & $563.00 \mathrm{gm}$ & E10.602.PC & 05.01 \\
\hline U2bu GP-N10 & REG & $K 40$ & $2.24 E+04$ & $4.5 E+03$ & PCikg & 02-25-99 & soll & $622.00 \mathrm{gm}$ & E10.602.PC & $05-01$ \\
\hline
\end{tabular}

- Comments: Data generated from the gamma spectroscopy analyses of soil samples submitted to the laboratory on 2/25/99. 


\section{BECHTEL Analytical Services}

Mothod Type: RAGMA
Case No.: U-2bu Subsidence Crater

SDG No.: C205

\begin{tabular}{|c|c|c|c|c|c|c|c|c|c|c|}
\hline $\begin{array}{c}\text { Doe } \\
\text {....... Semple No. ....... }\end{array}$ & $\begin{array}{l}\text { Semple } \\
\text { Trpe }\end{array}$ & $\begin{array}{l}\text { Radio- } \\
\text { muclide }\end{array}$ & Poent & $\begin{array}{l}\text { Uncer- } \\
\text { telinty }\end{array}$ & $\begin{array}{l}\text { Ressint } \\
\text { Unita }\end{array}$ & $\begin{array}{c}\text { Anatycis } \\
\text { Dite }\end{array}$ & $\begin{array}{l}\text { Somple } \\
\text { Matrix }\end{array}$ & $\begin{array}{l}\text { Semplo } \\
\text { Stzo }\end{array}$ & Mothod No. & metenument 10 \\
\hline U2bu GP-N10 & REG & TH228 & $2.43 E+03$ & $4.6 E+02$ & pCriss & $02-25-98$ & solu & $622.00 \mathrm{gm}$ & E10.e02.PC & $05-01$ \\
\hline U2bu GP-N10 & REG & U 238 & $0.00 E+\infty$ & $0.0 E+\infty$ & pCing & $02-26-99$ & son. & $022.00 \mathrm{~cm}$ & E10.002.PC & $05-01$ \\
\hline U2tu GP-N10 & REG & AM241 & $0.00 E+\infty$ & $0.0 E+\infty$ & paks & $02-25-58$ & soln & $822.00 \mathrm{~cm}$ & E10.002.PC & $05-01$ \\
\hline U2w GP-N5 & REG & CO60 & $3.27 E+02$ & $1.8 E+02$ & pCikg & 02.25 .99 & son & $643.00 \mathrm{~cm}$ & E10.002.PC & $05-01$ \\
\hline U2tu GP-N5 & REG & K 40 & $2.44 E+04$ & $4.7 E+03$ & pC/kg & 02-25-98 & SOLL & $643.00 \mathrm{~mm}$ & E10.002.PC & $05-01$ \\
\hline U2tu GP-N5 & REG & RA226 & $1.38 E+03$ & $3.7 E+02$ & pClang & $02.25-89$ & sol. & $643.00 \mathrm{~cm}$ & E10.802.PC & $05-01$ \\
\hline U2tw GP-NS & REG & TH228 & $2.25 E+03$ & $4.3 E+02$ & pCikg & $02-25-99$ & son & $643.00 \mathrm{~cm}$ & E10.602.PC & $05-01$ \\
\hline U2tu GP-N5 & PEG & U 238 & $0.00 E+\infty$ & $0.0 E+\infty$ & pcing & $02 \cdot 25-99$ & son & $643.00 \mathrm{~cm}$ & E10.602.PC & 05.01 \\
\hline U2WU GP-N5 & REG & AM241 & $0.00 E+\infty 0$ & $0.0 E+\infty$ & pcing & 02.25-99 & soll & $843.00 \mathrm{~cm}$ & E10.602.PC & $05-01$ \\
\hline U2tw GP-N7 & REG & K 40 & $2.42 E+0.4$ & $4.7 E+03$ & pcikg & 02-25-99 & sol & $647.00 \mathrm{gm}$ & E10.602.PC & $05-01$ \\
\hline U2bu GP-N7 & REG & TH228 & $2.32 E+03$ & $4.4 E+02$ & pCing & $02-25-99$ & soll & $647.00 \mathrm{~cm}$ & E10.602.PC & $05-01$ \\
\hline U2bu GP-N7 & REG & U 238 & $0.00 E+\infty$ & $0.0 E+\infty$ & pCikg & $02.25-99$ & soll & $647.00 \mathrm{gm}$ & E10.602.PC & $05-01$ \\
\hline U2bu GP.N7 & REG & AM241 & $0.00 E+\infty$ & $0.0 E+\infty$ & pCing & 02-25-99 & soln & $647.00 \mathrm{~cm}$ & $E 10.602 . P C$ & $05-01$ \\
\hline U2bu GP-A10 & REG & K 40 & $2.20 E+04$ & $4.4 E+03$ & pCing & $02.25=99$ & SOl. & $814.00 \mathrm{~cm}$ & E10.602.PC & $05-01$ \\
\hline U2tw GP-A10 & REG & TH228 & $2.62 E+03$ & $4.7 E+02$ & $\mathrm{pC} / \mathrm{kg}$ & $02-25-99$ & SOH. & $614.00 \mathrm{gm}$ & $E 10.602 . P C$ & $05-01$ \\
\hline
\end{tabular}

Comments: Date generated from the gamma spectroscopy analyses of soil samples submitted to the laboratory on $2 / 25 / 99$. 
Method Type: RAGMA SDG No.: C205

\begin{tabular}{|c|c|c|c|c|c|c|c|c|c|c|}
\hline ....... Sample No....... & $\begin{array}{l}\text { Sample } \\
\text { Type }\end{array}$ & $\begin{array}{l}\text { Radio- } \\
\text { nuclide }\end{array}$ & Result & $\begin{array}{l}\text { Uncer- } \\
\text { tainty }\end{array}$ & $\begin{array}{l}\text { Result } \\
\text { Units }\end{array}$ & $\begin{array}{l}\text { Analysis } \\
\text { Date }\end{array}$ & $\begin{array}{l}\text { Sample } \\
\text { Matrix }\end{array}$ & $\begin{array}{l}\text { Sample } \\
\text { Size }\end{array}$ & Method No. & Instrument ID \\
\hline U2bu GP-A10 & REG & U 238 & $0.00 E+00$ & $0.0 E+00$ & pCI/kg & 02-25-99 & soll & $614.00 \mathrm{gm}$ & E10.602.PC & 05-01 \\
\hline U2bu GP-A10 & REG & AM241 & $0.00 E+00$ & $0.0 E+\infty$ & pCinkg & 02-25-99 & soll & $614.00 \mathrm{gm}$ & E10.602.PC & 05-01 \\
\hline U2bu GP-A7 & REG & $K 40$ & $2.38 E+04$ & $4.7 E+03$ & $\mathrm{pC} / \mathrm{kg}$ & $02-25-99$ & soll. & $618.00 \mathrm{gm}$ & E10.602.PC & $05-01$ \\
\hline U2bu GP-A7 & REG & RA226 & $1.53 E+03$ & $4.0 E+02$ & PCing & 02-25-99 & Soll & $618.00 \mathrm{gm}$ & E10.602.PC & 05-01 \\
\hline U2bu GP.A7 & REG & TH228 & $2.00 E+03$ & $4.0 E+02$ & PCi/kg & $02-25-99$ & soll & $618.00 \mathrm{gm}$ & E10.602.PC & $05-01$ \\
\hline U2bu GP-A7 & REG & U 238 & $0.00 E+00$ & $0.0 E+00$ & PCIng & $02-25-99$ & Soll & $618.00 \mathrm{gm}$ & E10.602.PC & 05.01 \\
\hline U2bu GP-A7 & REG & AM241 & $0.00 E+00$ & $0.0 E+\infty 0$ & $\mathrm{pC} / \mathrm{kg}$ & $02-25-99$ & Soll & $618.00 \mathrm{gm}$ & E10.602.PC & 05.01 \\
\hline U2bu GP-S1 & AEG & AM241 & $1.00 E+03$ & $5.8 E+02$ & pCi/kg & 02-25-99 & soll & $690.00 \mathrm{gm}$ & E10.602.PC & $05-01$ \\
\hline U2bu GP-S1 & REG & CO60 & $3.68 E+03$ & $6.1 E+02$ & pCi/kg & $02-25-99$ & soll & $690.00 \mathrm{gm}$ & $E 10.602 . P C$ & 05.01 \\
\hline U2bu GP-S1 & REG & CS137 & $8.99 E+02$ & $2.3 E+02$ & PCi/kg & $02-25-99$ & SOIL & $690.00 \mathrm{gm}$ & E10.602.PC & $05-01$ \\
\hline U2bu GP-S1 & REG & K 40 & $2.57 E+04$ & $4.9 E+03$ & pCi/kg & $02-25-99$ & soll & $690.00 \mathrm{gm}$ & E10.602.PC & 05-01 \\
\hline U2bu GP-S1 & REG & RA226 & $1.75 E+03$ & $4.5 E+02$ & pCilkg & 02-25-99 & SOIL & $690.00 \mathrm{gm}$ & E10.602.PC & $05-01$ \\
\hline U2bu GP-S1 & REG & TH228 & $2.21 E+03$ & $4.5 E+02$ & PCI/kg & $02-26-99$ & soll. & $690.00 \mathrm{gm}$ & $E 10.602 . P C$ & $05-01$ \\
\hline U2bu GP-S1 & REG & U 238 & $0.00 E+00$ & $0.0 E+\infty 0$ & PCi/kg & 02-25-99 & soll & $690.00 \mathrm{gm}$ & E10.602.PC & $05-01$ \\
\hline U2bu GP-S10 & REG & $K 40$ & $2.06 E+04$ & $4.3 E+03$ & pCi/kg & 02-25-99 & soll. & $605.00 \mathrm{gm}$ & E10.602.PC & 05.01 \\
\hline
\end{tabular}

- Comments: Data generated from the gamma spectroscopy analyses of soil samples submitted to the laboratory on $2 / 25 / 99$. 
BECHTEL Analytical Services

Method Type: RAGMA
Case No.: U-2bu Subsidence Crater

SDG No.: C205

\begin{tabular}{|c|c|c|c|c|c|c|c|c|c|c|}
\hline ....... Semplo Ho. ....... & Semple & $\begin{array}{l}\text { Radlo- } \\
\text { nuclide }\end{array}$ & Reout & $\begin{array}{l}\text { Uheer- } \\
\text { twinty }\end{array}$ & $\begin{array}{l}\text { Romit } \\
\text { Units }\end{array}$ & $\begin{array}{c}\text { Anatrich } \\
\text { Dato }\end{array}$ & $\begin{array}{l}\text { Semplo } \\
\text { Matix }\end{array}$ & $\begin{array}{l}\text { Semph } \\
\text { Stae }\end{array}$ & Mothod No. & hatrument id \\
\hline U2bu GP-S10 & REG & RA226 & $1.66 E+03$ & $3.8 E+02$ & pCing & $02-25-20$ & son. & $605.00 \mathrm{~cm}$ & E10.002.PC & $05-01$ \\
\hline U2bu GP-S10 & PEG & TH228 & $2.43 E+03$ & $4.4 E+02$ & pcikg & $02-25-80$ & sol. & $605.00 \mathrm{~cm}$ & E10.002.PC & $05-01$ \\
\hline U2wu CP-S10 & REQ & U 238 & $0.00 E+\infty 0$ & $0.0 E+\infty$ & pcikg & $02-26-89$ & son & $005.00 \mathrm{~cm}$ & $E 10.002 . P C$ & $05-01$ \\
\hline U2bu GP-S10 & REG & AM241 & $0.00 E+\infty$ & $0.0 E+\infty$ & pcriks & $02-25-20$ & sol. & $805.00 \mathrm{gm}$ & E10.602.PC & $05-01$ \\
\hline U2bu GP-S5 & REG & $K 40$ & $2.24 E+04$ & $4.4 E+03$ & perikg & $02-26-29$ & son & $025.00 \mathrm{gm}$ & E10.e02.PC & $05-01$ \\
\hline U2bu GP-S6 & REG & RA226 & $1.53 E+03$ & $3.6 E+02$ & pClng & $02-25-90$ & sol. & $826.00 \mathrm{gm}$ & E10.002.PC & $05-01$ \\
\hline U26u CP-S5 & REG & TH228 & $1.93 E+03$ & $3.9 E+02$ & PCIng & 02-25-98 & sol & $825.00 \mathrm{~cm}$ & E10.602.PC & $05-01$ \\
\hline U2tu CP-S5 & REG & U 238 & $0.00 \varepsilon+\infty$ & $0.0 E+\infty$ & PCikp & $02-25-89$ & sol. & $825.00 \mathrm{~mm}$ & E10.002.PC & $05-01$ \\
\hline U2bu GP-S5 & PEEG & AM241 & $0.00 E+\infty 0$ & $0.0 E+\infty$ & penkg & 02-26-99 & solk & $625.00 \mathrm{~cm}$ & E10.002.PC & $05-01$ \\
\hline U2bu GP-S7 & PEG & $\times 40$ & $2.16 E+04$ & $4.4 E+03$ & pCAng & $02-25-89$ & son. & $527.00 \mathrm{~cm}$ & E10.802.PC & $05-01$ \\
\hline U2bu GP-S7 & REG & $\mathrm{TH} 228$ & $2.17 E+03$ & $4.3 E+02$ & pcikg & 02-25-99 & sol. & $527.00 \mathrm{gm}$ & E10.602.PC & $05-01$ \\
\hline U2bu GP-S7 & REG & U 238 & $0.00 E+\infty$ & $0.0 E+\infty$ & pang & 02-25-99 & soll & $527.00 \mathrm{gm}$ & E10.602.PC & $05-01$ \\
\hline U2bu GP-S7 & REG & AM241 & $0.00 E+\infty 0$ & $0.0 E+\infty$ & pCikg & $02-25-99$ & soll & $627.00 \mathrm{~cm}$ & E10.802.PC & $05-01$ \\
\hline U2bu OP-W1 & REG & K 40 & $2.65 E+04$ & $5.0 E+03$ & pCAng & 02-25-99 & soli. & $086.00 \mathrm{~cm}$ & E10.602.PC & $05-01$ \\
\hline U2bu GP-W1 & REG & TH228 & $2.57 E+03$ & $4.6 E+02$ & pCing & $02-25-99$ & SOIL & $688.00 \mathrm{gm}$ & E10.602.PC & $05-01$ \\
\hline
\end{tabular}

- Comments: Data generated from the gamma spectroscopy analyses of soil samples submitted to the laboratory on $2 / 25 / 99$. 
RADIOMETRIC ANALYSIS RESULTS

BECHTEL Analytical Services

Case No.: U-2bu Subsidence Crater

Method Type: RAGMA

SDG No.: C205

\begin{tabular}{|c|c|c|c|c|c|c|c|c|c|c|}
\hline ....... Sample No........ & $\begin{array}{l}\text { Semple } \\
\text { Type }\end{array}$ & $\begin{array}{l}\text { Radio- } \\
\text { nuclide }\end{array}$ & Result & $\begin{array}{l}\text { Uncer- } \\
\text { tainty }\end{array}$ & $\begin{array}{l}\text { Result } \\
\text { Units }\end{array}$ & $\begin{array}{l}\text { Analysis } \\
\text { Date }\end{array}$ & $\begin{array}{l}\text { Sample } \\
\text { Matrix }\end{array}$ & $\begin{array}{l}\text { Samplo } \\
\text { Size }\end{array}$ & Method No. & Instrument iD \\
\hline U2bu GP.W1 & REG & TH232 & $1.73 E+03$ & $6.0 E+02$ & pCifkg & 02-25-99 & SOIL: & $686.00 \mathrm{~cm}$ & $E 10.602 . P C$ & $05-01$ \\
\hline U2bu GP.W1 & REG & U 238 & $0.00 E+\infty 0$ & $0.0 E+\infty$ & pCilkg & 02-25.99 & SOIL & $686.00 \mathrm{gm}$ & E10.602.PC & $05-01$ \\
\hline U2bu GP.W1 & REG & AM241 & $0.00 E+00$ & $0.0 E+\infty$ & pCilks & 02-25-99 & solt & $686.00 \mathrm{gm}$ & E10.602.PC & 05-01 \\
\hline U2bu GP-W10 & REG & K 40 & $2.39 E+04$ & $4.7 E+03$ & PCikg & 02-25-99 & solt & $597.00 \mathrm{gm}$ & E10.602.PC & $05-01$ \\
\hline U2bu GP.W10 & REG & TH228 & $2.40 E+03$ & $4.5 E+02$ & pCing & $02-25-99$ & solt & $597.00 \mathrm{gm}$ & E10.602.PC & $05-01$ \\
\hline U2bu GP-W10 & REG & U 238 & $0.00 E+00$ & $0.0 E+\infty$ & pCikg & $02-25-99$ & soll. & $597.00 \mathrm{gm}$ & E10.602.PC & $05-01$ \\
\hline U2bu GP.W10 & REG & AM241 & $0.00 E+\infty 0$ & $0.0 E+00$ & pCing & 02-25-99 & soll. & $597.00 \mathrm{gm}$ & E10.602.PC & $05-01$ \\
\hline U2bu GP.W5 & REG & $K 40$ & $2.51 E+04$ & $4.9 E+03$ & pCing & 02-25-99 & soIL & $542.00 \mathrm{gm}$ & E10.602.PC & 05-01 \\
\hline U2bu GP-W5 & AEG & RA226 & $1.47 E+03$ & $3.7 E+02$ & pCing & 02-25-99 & solt. & $542.00 \mathrm{gm}$ & E10.602.PC & 05.01 \\
\hline U2bu GP-W5 & REG & TH228 & $1.82 E+03$ & $3.9 E+02$ & pCikg & 02-25-99 & soll & $542.00 \mathrm{gm}$ & E10.602.PC & 05.01 \\
\hline U2bu GP-W5 & REG & U 238 & $0.00 E+00$ & $0.0 E+00$ & pCi/kg & 02-25-99 & soll & $542.00 \mathrm{gm}$ & $E 10.602 . P C$ & $05-01$ \\
\hline U2bu GP-W5 & REG & AM241 & $0.00 E+00$ & $0.0 E+00$ & pCi/kg & $02-25-99$ & soll & $542.00 \mathrm{gm}$ & E10.602.PC & $05-01$ \\
\hline U2bu GP-W7 & REG & K 40 & $2.41 E+04$ & 4.7E+03 & pCi/kg & 02-25-99 & soll. & $622.00 \mathrm{gm}$ & E10.602.PC & 05.01 \\
\hline U2bu GP-W7 & REG & TH228 & $1.96 E+03$ & $4.0 E+02$ & $\mathrm{pCi} / \mathrm{kg}$ & $02-25-99$ & SOIL. & $622.00 \mathrm{gm}$ & E10.602.PC & $05-01$ \\
\hline U2bu GP-W7 & REG & U 238 & $0.00 E+00$ & $0.0 E+00$ & pCi/kg & $02-25-99$ & SOIL & $622.00 \mathrm{gm}$ & E10.602.PC & $05-01$ \\
\hline
\end{tabular}

- Comments: Data generated from the gamma spectroscopy analyses of soil samples submitted to the laboratory on $2 / 25 / 99$. 
RADIOMETRIC ANALYSIS RESULTS

BECHTEL Analytical Services

Method Type: RAGMA

\section{Case No.: U-2bu Subsidence Crater}

SDG No.: C205

\begin{tabular}{|c|c|c|c|c|c|c|c|c|c|c|}
\hline 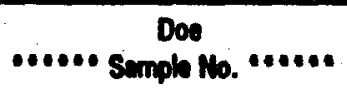 & $\begin{array}{l}\text { Semple } \\
\text { Type }\end{array}$ & $\begin{array}{l}\text { Radio- } \\
\text { muclido }\end{array}$ & Prout & Uneer- & $\begin{array}{l}\text { Reschen } \\
\text { Unitu }\end{array}$ & $\begin{array}{c}\text { Analych } \\
\text { Dato }\end{array}$ & Semplo & Semple & Minthod No. & hrottrument DD \\
\hline U2bu GP-W7 & AEG & AM241 & $0.00 E+\infty$ & $0.0 E+\infty$ & peaks & $02-25-00$ & son. & $822.00 \mathrm{~cm}$ & E10.002.FC & 05-01 \\
\hline
\end{tabular}


RADIOMETRIC QA/OC RESULTS

\section{BECHTEL Analytical Services}

Method Type: RAGMA
Case No.: U-2bu Subsidence Crater

SDG No.: C205

\begin{tabular}{|c|c|c|c|c|c|c|c|c|c|c|}
\hline $\begin{array}{l}\text { Control Sample } \\
\text { Identification }\end{array}$ & $\begin{array}{l}\text { Sample } \\
\text { Type }\end{array}$ & $\begin{array}{l}\text { Pladio- } \\
\text { nuclide }\end{array}$ & $\begin{array}{c}\text { Peak Energy } \\
\text { KeV }\end{array}$ & $\begin{array}{c}\text { Measured } \\
\text { Value }\end{array}$ & $\begin{array}{l}\text { Known } \\
\text { Value }\end{array}$ & \% Diff. & Units & Mothod No. & Instrument ID & $\begin{array}{l}\text { Date of } \\
\text { Check }\end{array}$ \\
\hline QA BKG WATER UOB & CNTRL & No Nuclido & Not Appl. & $0.00 E+\infty 0$ & $0.00 E+00$ & & & E10.602.PC & $06-01$ & 022599 \\
\hline QA BKG WATER U06 & CNTRL & AM241 & Not Appl. & $0.00 E+\infty$ & $0.00 E+00$ & & pCing & $E 10.602 . P C$ & 06-01 & 022599 \\
\hline QA BKG WATER UOG & CNTRL & 10060 & Not Appl. & $0.00 E+00$ & $0.00 E+00$ & & pCing & E10.602.PC & 06-01 & 022599 \\
\hline OA BKG WATER UOG & CNTRL & CS137 & Not Appl. & $0.00 E+\infty$ & $0.00 E+\infty$ & & pCing & E10.602.PC & $06-01$ & 022599 \\
\hline QA SP:OAW-6 & CNTAL & AM241 & 69.7 & $3.21 E+05$ & $3.11 E+05$ & 3.1 & pCikg & E10.602.PC & $06-01$ & 022599 \\
\hline OA SP:OAW:6 & CNTRL & $C 060$ & 1173.1 & $3.16 E+05$ & $3.21 E+05$ & -1.9 & PCing & E10.602.PC & 06-01 & 022599 \\
\hline QA SP:OAW-6 & CNTRL & cs 137 & 661.6 & $2.68 E+05$ & $2.76 E+05$ & -2.7 & pCing & E10.602.PC & 06-01 & 022599 \\
\hline OA BKG EMPTY BTL U05 & CNTRL & No Nuclide & Not Appl. & $0.00 E+00$ & $0.00 E+\infty 0$ & & $\mathrm{pC} / \mathrm{kg}$ & E10.602.PC & $05-01$ & 022599 \\
\hline OA BKG EMPTY BTL U05 & CNTRL & AM241 & Not Appl. & $0.00 E+00$ & $0.00 E+00$ & & $\mathrm{pC} / \mathrm{kg}$ & E10.602.PC & $05-01$ & 022599 \\
\hline OA BKG EMPTY BTL UO5 & CNTRL & 10060 & Not Appl. & $0.00 E+00$ & $0.00 E+00$ & & pCing & E10.602.PC & 05.01 & 022599 \\
\hline QA BKG EMPTY BTL UO5 & CNTRL & $\operatorname{cs} 137$ & Not Appl. & $0.00 E+00$ & $0.00 E+00$ & & pCing & E10.602.PC & 05.01 & 022599 \\
\hline QA SP:NAS-A0271 & CNTRL & AM241 & 59.3 & $2.02 E+05$ & $1.80 E+05$ & 12.1 & pCing & E10.602.PC & $05-01$ & 022599 \\
\hline QA SP:NAS-A0271 & CNTRL & 1060 & 1172.9 & $3.37 E+05$ & $3.31 E+05$ & 1.7 & pCIng & E10.602.PC & $05-01$ & 022599 \\
\hline QA SP:NAS-A0271 & CNTRL & CS137 & 661.5 & $2.30 E+05$ & $2.26 E+05$ & 2.1 & pCirkg & E10.602.PC & 05.01 & 022599 \\
\hline QA BKG EMPTY BTL U05 & CNTRL & No Nuclide & Not Appl. & $0.00 E+00$ & $0.00 E+00$ & & pCing & E10.602.PC & $05-01$ & 022699 \\
\hline
\end{tabular}

. 


\section{RADIOMETRIC QA/OC RESULTS}

BECHTEL Analytical Services

Method Type: RAGMA
Case No.: U-2bu Subsidence Crater

SDG No.: C205

\begin{tabular}{|c|c|c|c|c|c|c|c|c|c|c|}
\hline $\begin{array}{l}\text { Control Semph } \\
\text { Ventification }\end{array}$ & Simplo & medio- & $\begin{array}{c}\text { Peak Enwor } \\
\text { KoV }\end{array}$ & $\begin{array}{l}\text { Mocound } \\
\text { Volves }\end{array}$ & $\begin{array}{l}\text { Knomn } \\
\text { Volue }\end{array}$ & $\mathbf{x D m}$ & Uhere & Mnthod No. & Intoriment is & $\begin{array}{l}\text { Date of } \\
\text { Check }\end{array}$ \\
\hline QA BKo EMPTY BTL 105 & CNTH & AM241 & Not Appl. & $0.00 E+\infty$ & $0.00 E+\infty$ & & pons & E10.602.PC & $05-01$ & 022698 \\
\hline QA EKG EMPTY ETL 105 & CNTR & coso & Mor Appl. & $0.00++\infty 0$ & $0.00 E+\infty$ & & peing & E10.e02.PC & $05-01$ & 022099 \\
\hline QA EXE ENPTY BTL LDS & CNTR & $\operatorname{cs} 137$ & Not Appol. & $0.00 E+\infty 0$ & $0.005+\infty$ & & paing & E10.002.PC & $05-01$ & 022699 \\
\hline on spinus-10271 & CNTIR & AM241 & 89.2 & $2.045+06$ & $1.00 z+00$ & 13.2 & pents & $E 10.602 . P C$ & $05-01$ & 022699 \\
\hline oa Sp:14as-10271 & CNTH & 10060 & 1172.8 & $3.32 E+06$ & $3.31 E+\infty 6$ & 0.2 & PChe: & E10.602.PC & 0501 & 022099 \\
\hline QA SP:NAS-A0271 & CNTRL & CS137 & 801.4 & $2.30 E+05$ & $2.26 t+05$ & 2.2 & perikg & $E 10.002 . P C$ & $05-01$ & 022698 \\
\hline
\end{tabular}

- Comments: 
COVER PAGE

Date: 26-APR-99

RADIOMETRIC DATA ANALYSIS PACKAGE

BECHTEL NEVADA Analytical Services

Method Type: RAALP

DOE NO.

U2bu GP.S1
Lab ID No.

H0625-H-75331

Case No.: U-2bu Subsidence Crater

SDG No.: $\mathbf{C 2 0 5}$

Sample Numbers

DOE No.

Lab 10 No.

Comments: Data generated from the isotopic plutonium analysis of one soil sample. Analysis was initiated based on SOW requirements.

Release of the data contained in this data package has been authorized by the Laboratory Manager or the Manager's designee, as verified by the following signature:

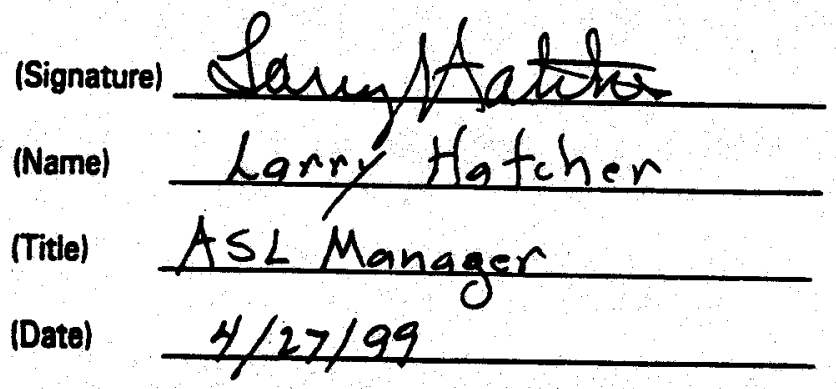

(N) 325 1/3) 
RADIOMETRIC ANALYSIS RESULTS

BECHTEL Analytical Services

Case No.: U-2bu Subsidence Crater

Method Type: RAALP

SDG No.: C205

\begin{tabular}{|c|c|c|c|c|c|c|c|c|c|c|}
\hline 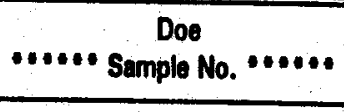 & $\begin{array}{l}\text { Sample } \\
\text { Type }\end{array}$ & $\begin{array}{c}\text { Radio- } \\
\text { nuclide }\end{array}$ & Rosult & $\begin{array}{l}\text { Uncer- } \\
\text { tainty }\end{array}$ & $\begin{array}{l}\text { Result } \\
\text { Units }\end{array}$ & $\begin{array}{c}\text { Analygis } \\
\text { Date }\end{array}$ & $\begin{array}{l}\text { Sample } \\
\text { Metrix }\end{array}$ & $\begin{array}{l}\text { Samplo } \\
\text { Sizo }\end{array}$ & Method No. & Instrument iD \\
\hline $\begin{array}{l}\text { U2bu GP-S1 } \\
\text { U2bu GP-S1 }\end{array}$ & $\begin{array}{l}\text { REG } \\
\text { REG }\end{array}$ & $\begin{array}{l}\text { PU239 } \\
\text { PU238 }\end{array}$ & $\begin{array}{l}8.65 E+02 \\
3.60 E+01\end{array}$ & $\begin{array}{l}2.9 E+02 \\
6.4 E+01\end{array}$ & $\begin{array}{l}\text { pCikg } \\
\text { pCing }\end{array}$ & $\begin{array}{l}04-20-99 \\
04-20-99\end{array}$ & $\begin{array}{l}\text { SOIL } \\
\text { SOIL. }\end{array}$ & $\begin{array}{l}0.10 \mathrm{gm} \\
0.10 \mathrm{gm}\end{array}$ & $\begin{array}{l}E 10.601 . P L \\
E 10.601 . P L\end{array}$ & $\begin{array}{l}30-10 \\
30-10\end{array}$ \\
\hline
\end{tabular}

- Comments: Data generated from the analysis of one soil sample. Analysis was initiated based on SOW requirements. 


\section{RADIOMETRIC QA/OC RESULTS}

BECHTEL Analytical Services

Method Type: RAALP
Case No.: U-2bu Subsidence Crater

SDG No.: C205

\begin{tabular}{|c|c|c|c|c|c|c|c|c|c|c|}
\hline $\begin{array}{l}\text { Control Sample } \\
\text { Identification }\end{array}$ & \begin{tabular}{|l} 
Sample \\
Type
\end{tabular} & $\begin{array}{l}\text { Radio- } \\
\text { nuclida }\end{array}$ & $\begin{array}{c}\text { Peak Energy } \\
\text { KoV. }\end{array}$ & \begin{tabular}{|c|} 
Measured \\
Value
\end{tabular} & $\begin{array}{l}\text { Known } \\
\text { Value }\end{array}$ & \% Diff. & Units & Method No. & Instrument id & $\begin{array}{l}\text { Date of } \\
\text { Chack }\end{array}$ \\
\hline QA REA & MB & PU239 & Not Appl. & $-1.91 E-02$ & $0.00 E+00$ & & pCing & E10.601.PL & 30.14 & 042699 \\
\hline OA REA & MB & PU238 & Not Appl. & $-6.29 E+\infty 0$ & $0.00 E+00$ & & $\mathrm{pC} / \mathrm{kg}_{\mathrm{g}}$ & $E 10.601 . P L$ & $30-14$ & 042699 \\
\hline QA SP:PU1 & MS & PU239 & Not Appl. & $1.10 E+04$ & $1.18 E+04$ & -6.7 & pCing & & $30-09$ & 042699 \\
\hline
\end{tabular}

- Comments: 


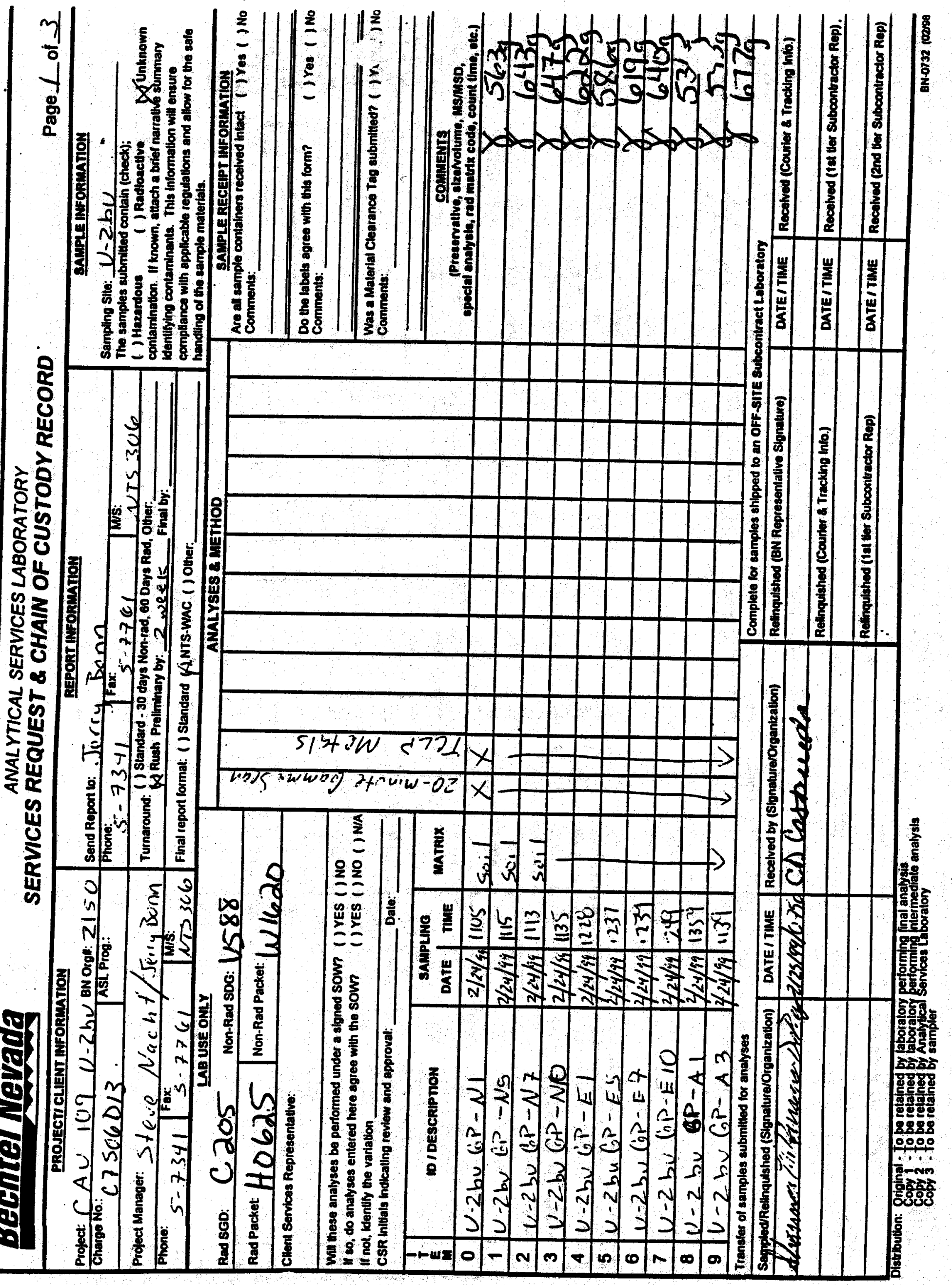




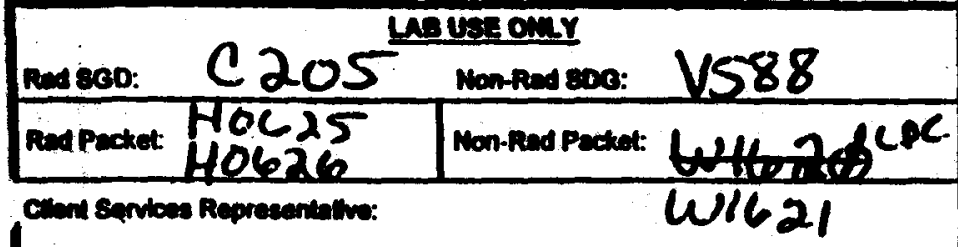

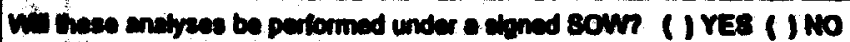

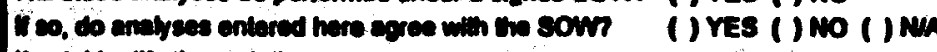
If nol bentery the vartation

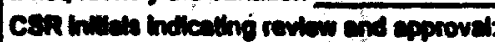
Den:

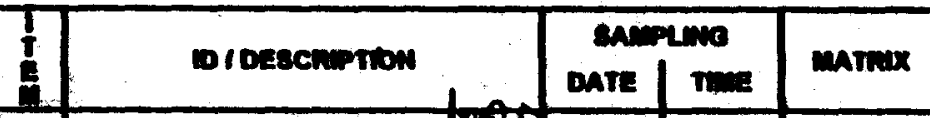

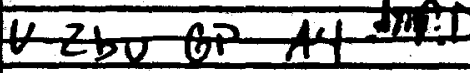

- 1 U-2 bu GP-AS

- 2 U-2bU GP-AZ

- 3 V-2 bV $6 P-A N$

- 4 EB22499

-5 V V-2bV $8 p-1 W / 1$

6 - $v-2$ bv (ip- W 5

$7 \quad \forall-2$ bU C.P-W7

- 8 U-2 bu GP-W10

- $8 \mid U-2$ LV GP- 51

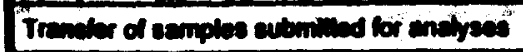

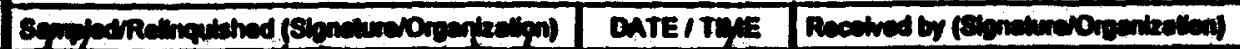

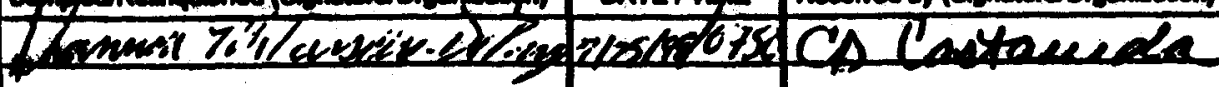

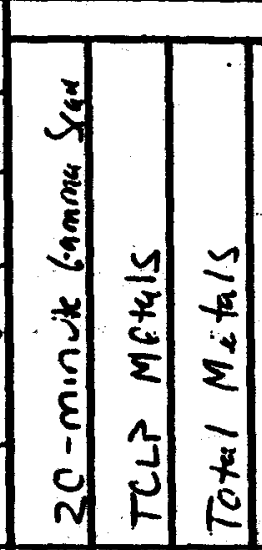

Soit-

\begin{tabular}{|l|l|l|}
\hline 50,1 & $X$ & $X$ \\
\hline
\end{tabular} 1409 so. $x$. $x$ 1415 1225 1532 soil $x \quad x$ water $x$ 1543 1610 1547 1359

$\operatorname{san} x \times$

$x$
soil so.1 soil VD
Amyras arofinos

\section{cancmormantom}

senping sen: $v-2$ bv

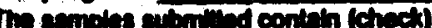

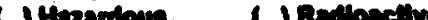

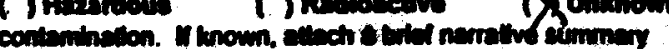

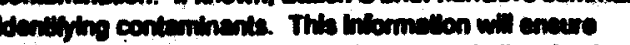

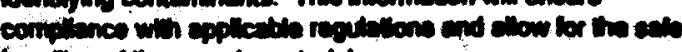
heneming of the semplo molatwe.

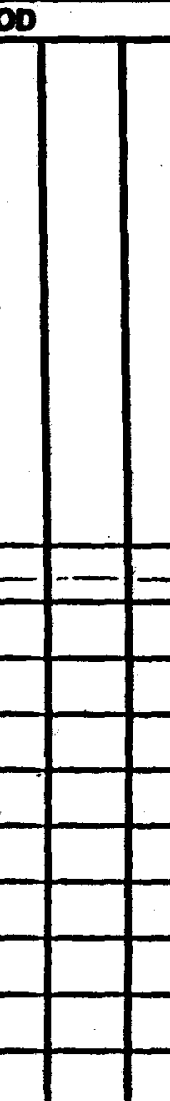

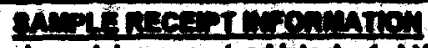

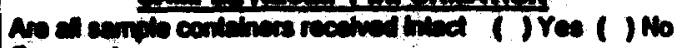
Comonomis:

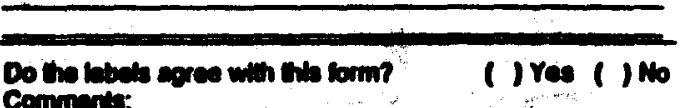

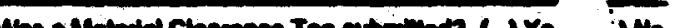
Commenta:

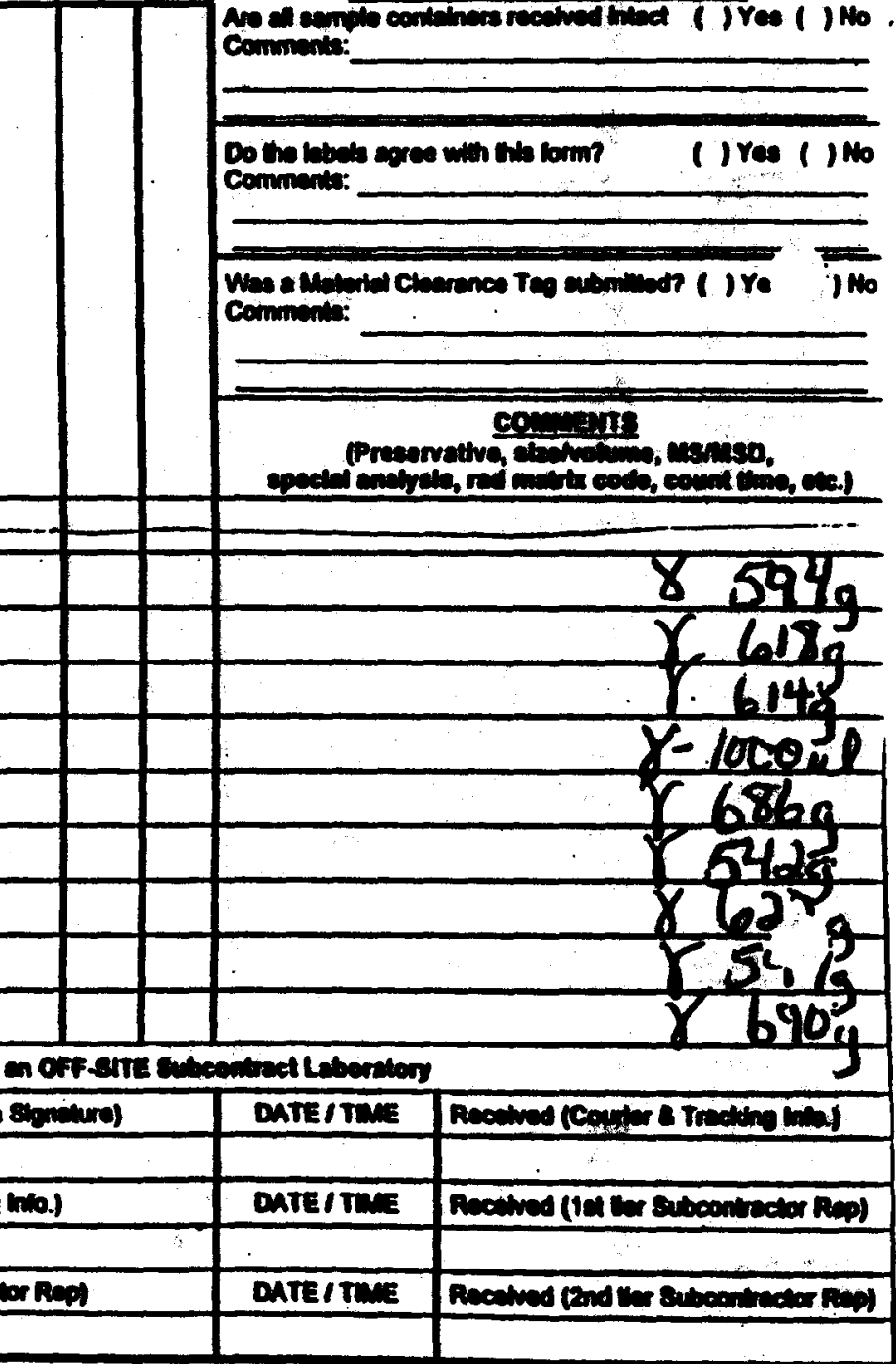

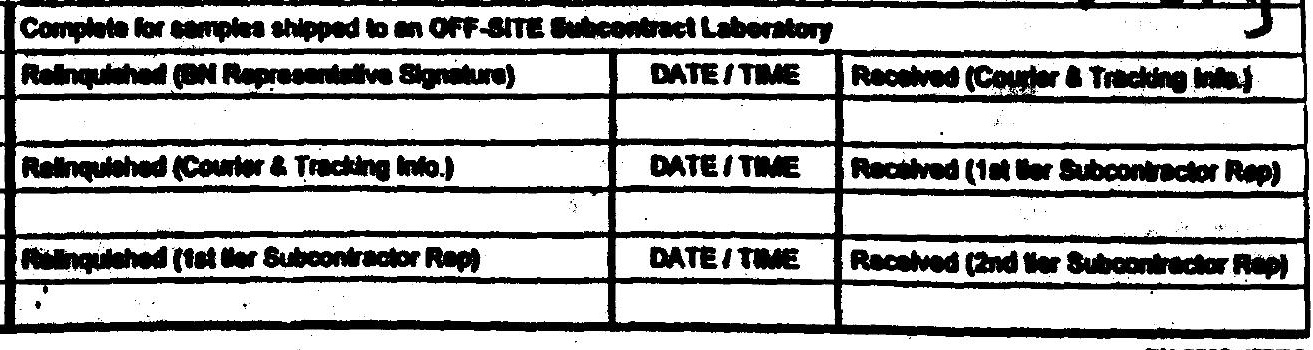




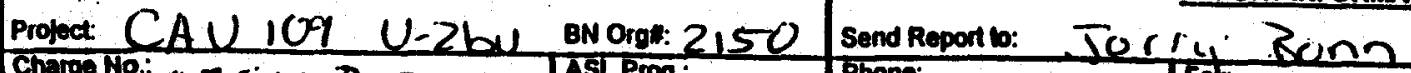

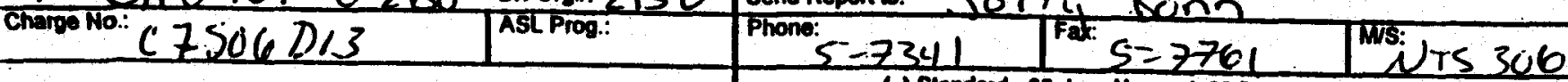

Prolect Manager: Steje Nacht

Phone: $\left.-7341{ }^{\text {Fax: }} 5-776\right)^{\text {Mis: }}$

Turnaround ( ) Standard - 30 days Non-rad, 60 Days Rad, Other Rush Prellinlnary by: 2 ule en Final by: Final report lormat: ( ) Standard So NTS-WAC ( ) Other.

Final by:

\section{Sampling SUle: $1-2$ bU}

The samples submitiod contain (check):

() Hazardous () Radloactive (X) Unknown

contamination. If known, attach a brlet narrative summary

vientliying contaminants. This information will ensure

\begin{tabular}{|c|c|c|}
\hline ad sed: $C_{205}$ & $\begin{array}{l}\text { IUSE OMLY } \\
\text { Non-Rad SDG: }\end{array}$ & $4 / 588$ \\
\hline Rad Packet: $H 0625$ & Non-Rad Packet: & W/6 \\
\hline
\end{tabular}

ent Sondces Representative:

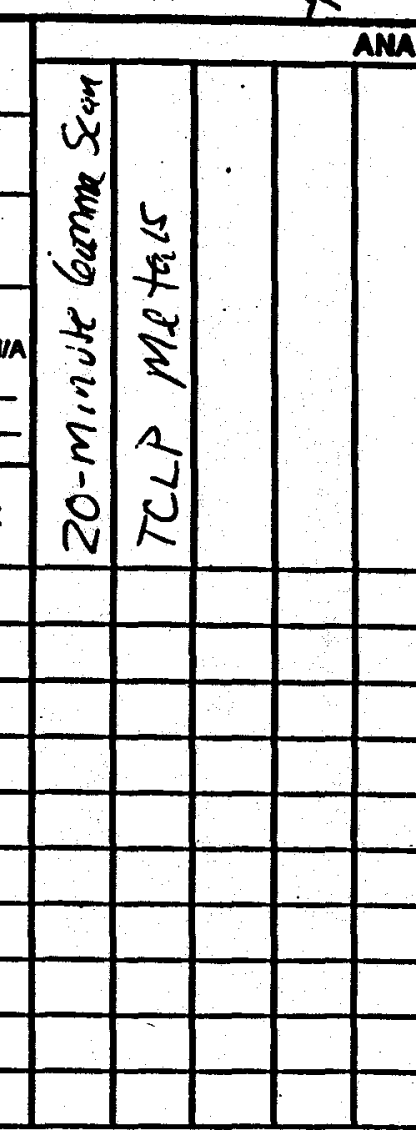

compllance with applicable regulations and allow for the safe handing of the sample matertals.

Win these analyses be performed under a signed sOW? () YES ( ) NO

If so, do analyses entered here agree with the SOWn? (I YES ( ) NO ( ) NA

If not, Identily the varlatlon

CSR mittals molicating review and approval: ___ _ _ Dale:

7 T

t

- 0 U-2bv GP-SS

- 1 U-2bV GP-S7

- $2 U-2 b V 6 P-510$

3 t-2b

$\frac{4}{5}$

\begin{tabular}{|l|l|}
\hline 3 & \\
\hline 7 & \\
\hline 8 & \\
\hline 9 & \\
\hline
\end{tabular}

Transfer of samples submilted for analyses

\begin{tabular}{|c|c|c|}
\hline DATE & TINE & matrix \\
\hline $2 / 3 / 1 \%$ & 1455 & Sall \\
\hline $5 * 1$ & 1457 & \\
\hline$V$ & 1515 & $V$ \\
\hline & & \\
\hline & & \\
\hline & & \\
\hline & & \\
\hline & & \\
\hline & & \\
\hline & & \\
\hline
\end{tabular}

ALYSES \& METHOD

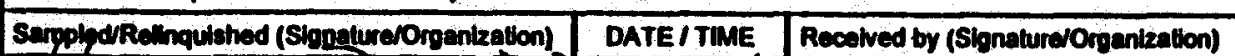

\begin{tabular}{|c|c|c|}
\hline 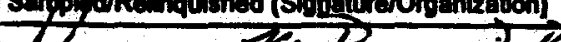 & DAIET MME & Recelved by (SIgnaturedorganization) \\
\hline & & . \\
\hline & 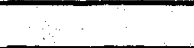 & \\
\hline & & \\
\hline
\end{tabular}

Complete for samples shipped to en OfF SITE Subcontract Laboratory

\begin{tabular}{|c|c|c|}
\hline Relinqulahod (BN Representalive Signature) & DATE / TME & Recolved (Courler \& Tracking info.) \\
\hline Relingulahed (Courler \& Tracking inlo.) & DATE / TMEE & Recelved (1at ther subcontrector Rop) \\
\hline Rolinquiahed (1st tier Subcontractor Rep) & DATE / TIME & Recolved (2nd ber Subcontructor Rep) \\
\hline 1 & & \\
\hline
\end{tabular}

SAMPLE RECEAPT MUFORLATION Are all sample containars recolved intact I Y Yes I I No Comments:

Do the labels agree with this form? $\quad$ ( ) Yes ( ) No Comments:

Was a Material Clearance Tag submithed? \& I Yes

Comments:

COMMENTS

cring

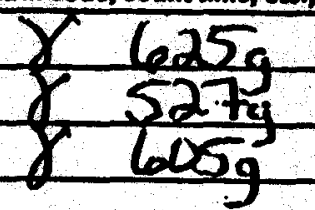




\section{COVER PAGE}

Date: 17-MAR-99

RADIOMETRIC DATA ANALYSIS PACKAGE

BECHTEL NEVADA Analytical Services

Method Type: RAGMA
Case No.: U-2bu Subsidence Crater

SDG No.: C217

\section{Sample Numbers}

$\begin{array}{lc}\text { DOE NO. } & \text { LOG 1O NO } \\ \text { U2BUBP-1 } & \text { HO665-0-75328 } \\ \text { U2BUBP-2 } & \text { HO665-1-75329 } \\ \text { U2BUBP-3 } & \text { HO665-2-75330 }\end{array}$

DOE NO.

Lab ID No.

0665-2.75330

Comments: Data generated from the gamma spectroscopy scans of three soil samples submitted to the laboratory on March 2, 1999.

Release of the data contained in this data package has been authorized by the Laboratory Manager or the Manager's designee, as verified by the following signature:

(Signature)

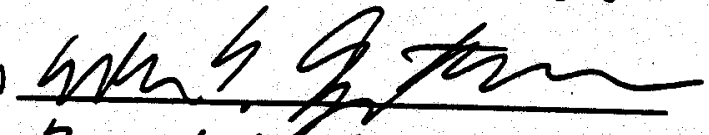

(Name)

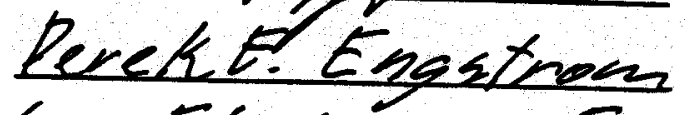

(Title)

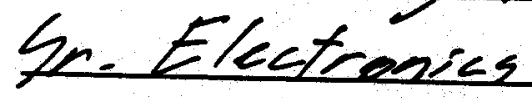

(Date)

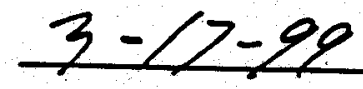


RADIOMETRIC ANALYSIS RESULTS

BECHTEL Analytical Services

Case No.: U-2bu Subsidence Crater

Method Type: RAGMA

SDG No.: $\mathrm{C217}$

\begin{tabular}{|c|c|c|c|c|c|c|c|c|c|c|}
\hline 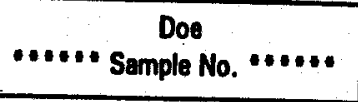 & $\begin{array}{l}\text { Sample } \\
\text { Trpo }\end{array}$ & $\begin{array}{l}\text { Radio- } \\
\text { nuclide }\end{array}$ & Result & $\begin{array}{l}\text { Uncer- } \\
\text { tainty }\end{array}$ & $\begin{array}{l}\text { Result } \\
\text { Units }\end{array}$ & $\begin{array}{c}\text { Analysis } \\
\text { Date }\end{array}$ & $\begin{array}{l}\text { Samplo } \\
\text { Matrix }\end{array}$ & $\begin{array}{l}\text { Sampla } \\
\text { Stzo }\end{array}$ & Method No. & Instrument 10 \\
\hline U2BuBP-1 & REG & $K 40$ & $1.95 E+04$ & $4.1 E+03$ & pCing & $03.02-99$ & soll & $484.00 \mathrm{gm}$ & E10.602.PC & 05-01 \\
\hline U2BuBP-1 & REG & TH228 & $2.07 E+03$ & 4.1E+02 & pCikg & 03-02-99 & SOH & $484.00 \mathrm{gm}$ & E10.602.PC & 05.01 \\
\hline U2BuBP-1 & REG & U 238 & $0.00 E+\infty 0$ & $0.0 E+\infty$ & pcing & 03.02-99 & soll. & $484.00 \mathrm{gm}$ & E10.602.PC & $05-01$ \\
\hline U2BuBP.1 & REG & AM241 & $0.00 E+00$ & $0.0 E+\infty$ & pCing & 03-02-99 & soll & $484.00 \mathrm{gm}$ & E10.602.PC & $05-01$ \\
\hline U2BuBP-2 & REG & K 40 & $2.32 E+04$ & $4.6 E+03$ & pCing & 03.02-99 & SOIL & $526.00 \mathrm{gm}$ & E10.602.PC & $05-01$ \\
\hline U2BUBP-2 & REG & TH228 & $2.00 E+03$ & $4.1 E+02$ & pCing & 03-02-99 & soil. & $526.00 \mathrm{gm}$ & E10.602.PC & $05-01$ \\
\hline U2BUBP-2 & REG & U 238 & $0.00 E+00$ & $0.0 E+\infty$ & pcing & 03.02-99 & SOIL & $626.00 \mathrm{gm}$ & E10.602.PC & 05.01 \\
\hline U2BuBP-2 & REG & AM241 & $0.00 E+00$ & $0.0 E+\infty 0$ & pCing & 03.02 .99 & SOIL & $526.00 \mathrm{gm}$ & E10.602.PC & $05-01$ \\
\hline U2BUBP-3 & REG & K 40 & $2.19 E+04$ & $4.5 E+03$ & $\mathrm{pC} / \mathrm{kg}$ & 03-02-99 & soil. & $522.00 \mathrm{gm}$ & E10.602.PC & $05-01$ \\
\hline U2BUBP-3 & REG & TH228 & $2.42 E+03$ & $4.6 E+02$ & pCikg & 03.02-99 & SOIL & $522.00 \mathrm{gm}$ & E10.602.PC & $05-01$ \\
\hline U2BUBP.3 & REG & U 238 & $0.00 E+00$ & $0.0 E+00$ & pCikg & $03.02-99$ & soll & $522.00 \mathrm{gm}$ & E10.602.PC & $05-01$ \\
\hline U2BUBP-3 & REG & AM241 & $0.00 E+00$ & $0.0 E+\infty 0$ & pCing & $03-02.99$ & soll. & $522.00 \mathrm{gm}$ & & 05.01 \\
\hline
\end{tabular}

- Comments: 
BECHTEL Analytical Services

Method Type: RAGMA
Case No.: U-2bu Subsidence Crater

SDG No.: C217

\begin{tabular}{|c|c|c|c|c|c|c|c|c|c|c|}
\hline $\begin{array}{l}\text { Control Sample } \\
\text { Nentification }\end{array}$ & $\begin{array}{c}\text { Sample } \\
\text { Type }\end{array}$ & $\begin{array}{c}\text { Radio- } \\
\text { nuclide. }\end{array}$ & $\begin{array}{c}\text { Peok Energy } \\
\mathrm{KoV}\end{array}$ & \begin{tabular}{|c|}
$\begin{array}{c}\text { Measured } \\
\text { Value }\end{array}$ \\
\end{tabular} & $\begin{array}{l}\text { Known } \\
\text { Value }\end{array}$ & X Diff. & Units & Mothod No. & Instrument ID & $\begin{array}{l}\text { Dete of } \\
\text { Check }\end{array}$ \\
\hline OA BKG EMPTY BTL U05 & CNTRL & No Nuclide & Not Appl. & $0.00 E+\infty$ & $0.00 E+00$ & & & E10.602.PC & $05-01$ & 030899 \\
\hline QA BKG EMPTY BTL UDS & CNTRL & AM241 & Not Appl. & $0.00 E+\infty$ & $0.00 E+\infty 0$ & & $\mathrm{pCl} / \mathrm{kg}$ & $E 10.602 . P C$ & 05-01 & 030899 \\
\hline OA BKG EMPTY BTL UOS & CNTRL & CO60 & Not Appl: & $0.00 E+00$ & $0.00 E+\infty$ & & pCing & $E 10.602 . P C$ & $05-01$ & 030899 \\
\hline QA BKG EMPTY BTL U05 & CNTIR & CS137 & Not Appl. & $0.00 E+\infty$ & $0.00 E+\infty 0$ & & pCing & $E 10.602 . P C$ & 05.01 & 030899 \\
\hline QA SP:NAS-A0271 & CNTRL & AM241 & 59.2 & $2.00 E+05$ & $1.80 E+05$ & 11.1 & pCing & E10.602.PC & $05-01$ & 030899 \\
\hline QA SP:NAS-A0271 & CNTRL & $\operatorname{cos0}$ & 1172.9 & $3.39 E+05$ & $3.31 E+05$ & 2.6 & pcing & E10.602.PC & $05-01$ & 030899 \\
\hline QA SP:NAS-A0271 & CNTRL & CS137 & 661.6 & $2.32 E+0.5$ & $2.26 E+05$ & 2.9 & & E10.602.PC & $05-01$ & 030899 \\
\hline
\end{tabular}

- Comments: 


\section{PROJECT/CLIENT WFORMATION}

\begin{tabular}{|c|c|c|}
\hline Project: & $\frac{v i c}{013}$ & $\begin{array}{l}\text { BN Orge: } 2 / 50 \\
\text { ASL Prop: }\end{array}$ \\
\hline \multirow{2}{*}{\multicolumn{3}{|c|}{ Project Manager: Steve Nacht/Jerry Bonn }} \\
\hline & & MUS: \\
\hline
\end{tabular}

\begin{tabular}{ll|l} 
Rad SGD: $C 217$ & Non-Rad SDG: \\
\hline Rad Packet $H 0665$ & Non-Rad Packet:
\end{tabular}

Client Senvices Representative:

Wil these analyses be pertormed under a slgned SOWn () YES ( I NO

If so, do analyses entered here agree with the SOWn () YES ( ) NO ( ) NAA

If not, identify the variation

CSR initials indicating review and approval:

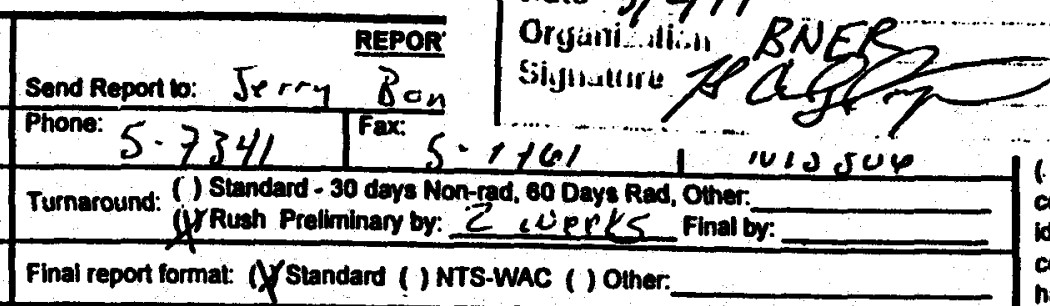

(1)

(.) Harandous

Page $L$ of 1

wed contain (check):

() Radioactive Y Uniknown

identifying contarninants. This information will ensure

compliance with applicable regutations and allow for the salo handling of the sample materials.

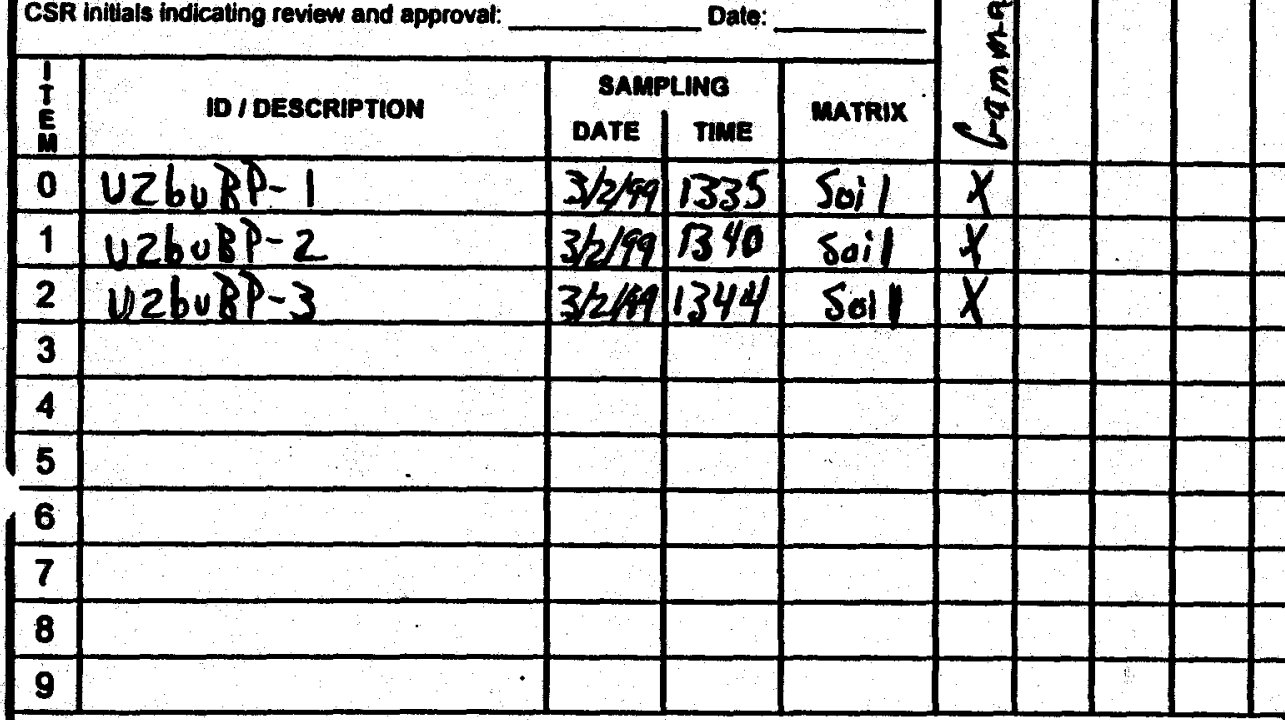

Transter of samples submitted for analyses
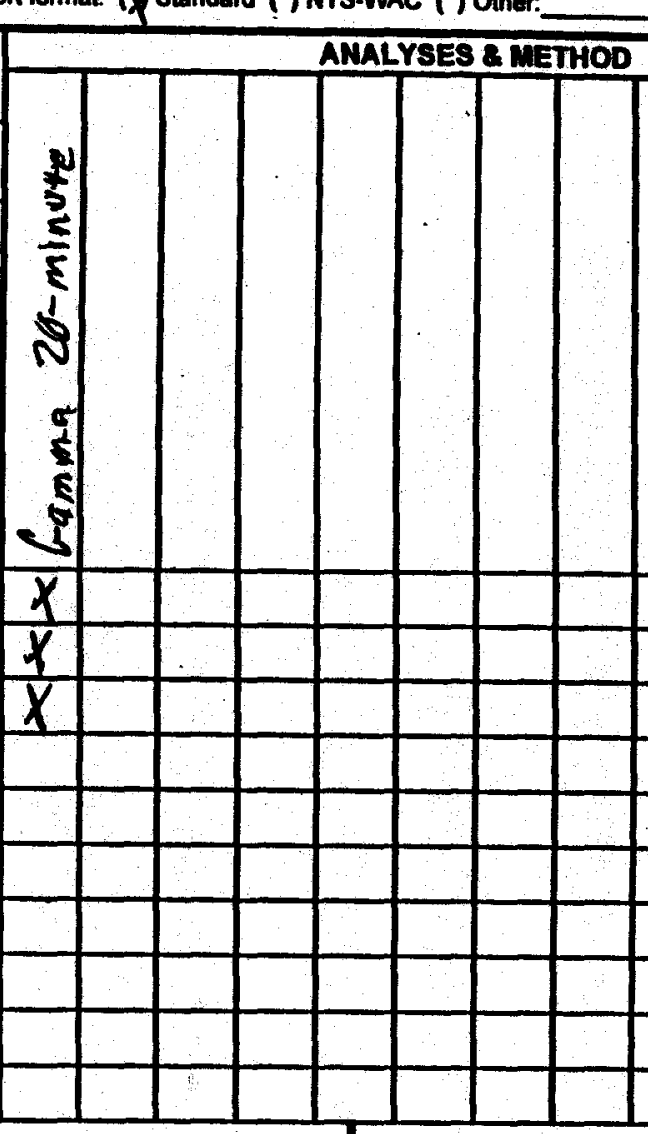

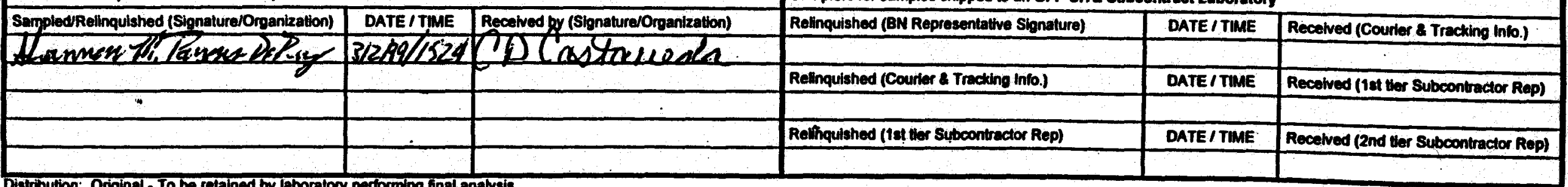

Complete for samples shipped to an OFF-sITE Subcontract Laboratory 
CLIENT: Bechtel Nerada

P.O. Box 98521 , MS NTS273

Las Vegas, NV 89193-8521

ATIN: Ted Redding

PROJECT NAME: V665

PROJECT NUMBER: 17777

NEL ORDER ID: L9907287

Artached are the andytical results for samples in support of the above referenced project.

Samples were received by NEI in good condition, under chain of eustody on 7/28/99.

Samples were matyzed as received.

Should you have any questions or comments, please feel frae to contact our Client Services deparment at (702) 657-1010.

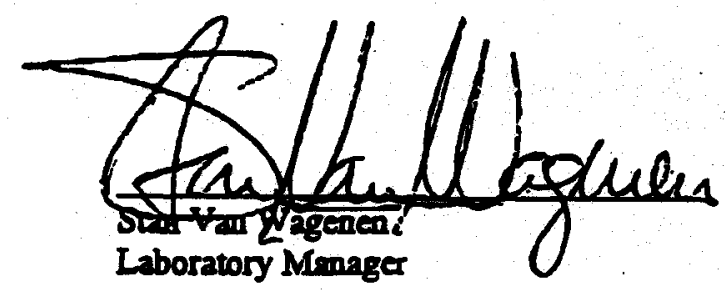

CERTIFICATIONS:

\begin{tabular}{|c|c|c|c|}
\hline & Reno & Las Vega & S. California \\
\hline & $\overline{A Z 0520}$ & AZ0518 & AZ0605 \\
\hline $\begin{array}{l}\text { Califormia } \\
\text { US Amny Corps }\end{array}$ & $\begin{array}{l}1707 \\
\text { Certified }\end{array}$ & $\begin{array}{l}2002 \\
\text { Centified }\end{array}$ & $\begin{array}{l}2264 \\
\text { Cerrified }\end{array}$ \\
\hline
\end{tabular}

$\begin{array}{llll} & \text { Reno } & \text { Las Vegas } & \text { S. Califormia } \\ \text { Idaho } & \text { Certified } & \text { Certified } & \\ \text { Montana } & \text { Centified } & \text { Certified } & \\ \text { Nevada Nv033 } & \text { NV052 } & \text { CA084 } \\ \text { L.AC.S.D. } & & & 10228\end{array}$




\begin{tabular}{|c|c|c|}
\hline $\begin{array}{l}\text { CLIENT: } \\
\text { PROJECT ID: } \\
\text { PROJECT \#: }\end{array}$ & $\begin{array}{l}\text { Bechrel Nevada } \\
\text { V665 } \\
17777\end{array}$ & $\begin{array}{l}\text { CIIENT ID: } \quad \text { U28UBOT - w } \\
\text { DATE SAMPLED: 7/28/99 } \\
\text { NEI SAMPLE ID: L9907287-01 }\end{array}$ \\
\hline $\begin{array}{l}\text { TEST: } \\
\text { MATRX: }\end{array}$ & $\begin{array}{l}\text { TCLP-8 Metals } \\
\text { Solid }\end{array}$ & \\
\hline
\end{tabular}

\begin{tabular}{|c|c|c|c|c|c|c|c|}
\hline PARAMITIER & $\begin{array}{c}\text { RESULT } \\
\text { mel } \\
\end{array}$ & $\begin{array}{l}\text { REPORTING } \\
\text { LMIT } \\
\end{array}$ & D.F. & MITIOD & $\begin{array}{c}\text { TCLPISTLC } \\
\text { EXIRACTION } \\
\text { DATE } \\
\end{array}$ & DIGESTED & ANAIYZADD \\
\hline Arsenic & ND & $0.1 \mathrm{mpl}$ & 1 & EPA $\$ 010$ & $8 / 1 / 99$ & $8 / 2 / 99$ & $8 / 2 / 99$ \\
\hline Berium & ND & 1. $m e / 1$ & 1 & EPA 6010 & $8 / 1 / 99$ & $8 / 2 / 99$ & $8 / 2 / 99$ \\
\hline Cadrimen & ND & $0.01 \mathrm{men}$ & 1 & EPA 6010 & $8 / 1 / 99$ & $8 / 2 / 99$ & $8 / 2 / 99$ \\
\hline Chrocming & ND & $0.01 \mathrm{mog}$ & 1 & EPA 6010 & $8 / 1 / 99$ & $8 / 2 / 99$ & 8/2/99 \\
\hline Lead & ND & $0.05 \mathrm{mel}$ & 1 & EPA 6010 & $8 / 1 / 99$ & $8 / 2 / 99$ & $8 / 2 / 99$ \\
\hline Mercury & ND & $0.002 \mathrm{~mol}$ & 10 & EPA 7470A & $8 / 1 / 99$ & $8 / 2 / 99$ & $8 / 2 / 99$ \\
\hline Seloninum & ND & $0.1 \mathrm{me} / \mathrm{L}$ & 1 & EPA Q010 & $8 / 1 / 99$ & $8 / 2 / 99$ & $8 / 2 / 99$ \\
\hline Silver & ND & $0.02 \operatorname{met} 2$ & 1 & EPA & $8 / 1 / 99$ & $8 / 2 / 99$ & $8 / 2 / 99$ \\
\hline
\end{tabular}

D.F. - Dilution Factor

ND - Not Detected

This report shall not be reproduced except in full, without the wrizen apptoval of the laboratory. 


\section{NEL LABORATORIES}

\section{CLIENT: Bechicl Nerads}

PROJECT D: V665

PROJECT \#: $\quad 17777$

TEST:

MATRDX:

TCLP-8 Metals

Solid
CLIENT ID:

DATE SAMPLED: 7/28/99

NEL SAMPLE ID: L9907287-02

\section{PARAMITER}

Arrenic

Burium

Cadremingen

Chroteiven

Load

Mereory

Solenium

Silver

\section{RESULT RFORTING}

me 1

ND

ND

ND

ND

ND

ND

ND

ND
LMIT

$0.1 \operatorname{mog} 1$

$1 . m=2$

$0.01 \mathrm{mg} /$

$0.01 \mathrm{med}$

$0.05 \mathrm{~mol}$

$0.002 \mathrm{mgh}$

$0.1 \mathrm{mel}$

$0.02 \mathrm{mg} / \mathrm{L}$
D. F. METEOD

EPA 6010

EPA 6010

EPA 6010

EPA 6010

EPA 6010

EPA $7470 A$

EPA 6010

EPA 6010

\section{TCLPSTLC}

EXTRACTION DATS

DIGESTXD ANALYZATD

$$
8 / 1 / 99
$$

$8 / 1 / 99$

$8 / 1 / 99$

$8 / 1 / 99$

$8 / 1 / 99$

$8 / 1 / 99$

$8 / 1 / 99$

$8 / 1 / 99$

$8 / 2 / 99 \quad 8 / 2 / 99$

$8 / 2 / 99 \quad 8 / 2 / 99$

$8 / 2 / 99 \quad 8 / 2 / 99$

$8 / 2 / 99 \quad 8 / 2 / 99$

$8 / 2 / 99 \quad 8 / 2 / 99$

$8 / 2 / 99 \quad 8 / 2 / 99$

$8 / 2 / 99 \quad 8 / 2 / 99$

$8 / 2 / 99 \quad 8 / 2 / 99$

D.F. - Dilution Fector

VD - Not Detected

This report shall not be reproduced except in full, without the writen apploval of the laboratory. 


\begin{tabular}{|c|c|c|c|}
\hline $\begin{array}{l}\text { CLIENT: } \\
\text { PROJECT D: } \\
\text { PROJECT \#: }\end{array}$ & $\begin{array}{l}\text { Bechinel Nevada } \\
\text { V665 } \\
17777\end{array}$ & $\begin{array}{l}\text { CLENT ID: } \\
\text { DATE SAMPLED: } \\
\text { NEL \$AMPLE D: }\end{array}$ & $\begin{array}{l}\text { U2BOEOT - N75 } \\
7 / 28 / 99 \\
\text { L9907287-03 }\end{array}$ \\
\hline $\begin{array}{l}\text { TEST: } \\
\text { MATRX: }\end{array}$ & $\begin{array}{l}\text { TCLP-8 Metals } \\
\text { Solid }\end{array}$ & & \\
\hline
\end{tabular}

\begin{tabular}{|c|c|c|c|c|c|c|c|}
\hline PARAMIETLR & $\begin{array}{c}\text { RESULT } \\
\text { me }\end{array}$ & $\begin{array}{c}\text { REPORTING } \\
\text { LIMIT } \\
\end{array}$ & D. F. & Merion & $\begin{array}{c}\text { TCLPSTLC } \\
\text { EXTRACIION } \\
\text { DATE } \\
\end{array}$ & DIGESTIX & ANALYZAOD \\
\hline Arenic & ND & $0.1 \mathrm{mg} / \mathrm{L}$ & 1 & EPA 6010 & $8 / 1 / 99$ & $8 / 2 / 99$ & $8 / 2 / 99$ \\
\hline Berium & ND & 1. $m$ & 1 & EPA 6010 & $8 / 1 / 99$ & $8 / 2 / 99$ & $8 / 2 / 99$ \\
\hline Cucterniuen & ND & $0.01 \mathrm{mgl}$ & 1 & EPA 6010 & $8 / 1 / 99$ & $8 / 2 / 99$ & $8 / 2 / 99$ \\
\hline Chromingm & ND & $0.01 \mathrm{men}$ & 1 & EPA 6010 & $8 / 1 / 99$ & $8 / 2 / 99$ & $8 / 2 / 99$ \\
\hline Lead & ND & $0.05 \mathrm{mg} / \mathrm{L}$ & 1 & EPA 6010 & $8 / 1 / 99$ & $8 / 2 / 99$ & $8 / 2 / 99$ \\
\hline Mercury & ND & $0.002 \mathrm{mg} / \mathrm{L}$ & 10 & EPA 7470A & $8 / 1 / 99$ & $8 / 2 / 99$ & $8 / 2 / 99$ \\
\hline Seleninem & ND & $0.1 \mathrm{mg} / \mathrm{L}$ & 1 & EPA Q010 & $8 / 1 / 99$ & $8 / 2 / 99$ & $8 / 2 / 99$ \\
\hline Silver & ND & $0.02 \mathrm{~mol}$ & 1 & EPA 6010 & $8 / 1 / 99$ & $8 / 2 / 99$ & $8 / 2 / 99$ \\
\hline
\end{tabular}

D.F. - Dilution Factor

ND - Not Delccled

This report shall not be reproduced except in full, without the written apptoval of the laboratory. 


\begin{tabular}{|c|c|c|}
\hline $\begin{array}{l}\text { CUIENT: } \\
\text { PROJECT D: } \\
\text { PROJECT \#: }\end{array}$ & $\begin{array}{l}\text { Bechred Nevadn } \\
\text { V665 } \\
17777\end{array}$ & $\begin{array}{l}\text { CLIENT D: } \\
\text { DATE SAMPLED: } 7 / 28 / 99 \\
\text { NEL SAMPLE ID: } 29907287-04\end{array}$ \\
\hline $\begin{array}{l}\text { TEST: } \\
\text { MATRIX: }\end{array}$ & $\begin{array}{l}\text { TCLP-S Metals } \\
\text { Solid }\end{array}$ & \\
\hline
\end{tabular}

\begin{tabular}{|c|c|c|c|c|c|c|c|}
\hline PARAMETIER & $\begin{array}{c}\text { RESULT } \\
\text { mel } \\
\end{array}$ & $\begin{array}{c}\text { REPORTING } \\
\text { LMMIT }\end{array}$ & D.F. & METHOD & $\begin{array}{c}\text { TCLPSTILC } \\
\text { EXTRMCTION } \\
\text { DATE } \\
\end{array}$ & DIGESTED & ANALYZADD \\
\hline $\begin{array}{l}\text { Anenwic } \\
\text { Berium }\end{array}$ & ND & $0.1 \mathrm{med}$ & 1 & EPA 6010 & $8 / 1 / 99$ & $8 / 2 / 99$ & $8 / 2 / 99$ \\
\hline $\begin{array}{l}\text { Berrivem } \\
\text { Cadmatumen }\end{array}$ & $\begin{array}{l}\text { ND } \\
\text { ND }\end{array}$ & $\begin{array}{r}1 . m e / 2 \\
0.01 \mathrm{mel}\end{array}$ & 1 & EPA 6010 & $8 / 1 / 99$ & 8/2/99 & $8 / 2 / 99$ \\
\hline Chromium & ND & $0.01 \mathrm{mon}$ & 1 & EPA 6010 & 8/1/99 & $8 / 2 / 99$ & $8 / 2 / 99$ \\
\hline Lead & N & $0.05 \mathrm{mgh}$ & 1 & EPA 6010 & 8/1/99 & $8 / 2 / 99$ & 8/2/99 \\
\hline Mercury & ND & $0.002 \mathrm{mgl}$ & 10 & EPA 7470A & $8 / 1 / 99$ & $8 / 2 / 99$ & 8/2/99 \\
\hline Selepoium & ND & $0.1 \operatorname{med}$ & 1 & EPACOIO & $\begin{array}{l}8 / 1 / 49 \\
8 / 1 / 99\end{array}$ & $\begin{array}{l}8 / 2 / 99 \\
80199\end{array}$ & 8/2199 \\
\hline Silver & ND & $0.02 \mathrm{meg} L$ & 1 & EPA 6010 & $8 / 1 / 99$ & $8 / 2 / 99$ & $\begin{array}{l}8 / 2 / 99 \\
8 / 2 / 99\end{array}$ \\
\hline
\end{tabular}

\section{D.F. - Ditution Factor \\ VD - Not Detected}

This report shall not be reproduced except in full, without the wrizen approval of the leboratory. 


$\begin{array}{lll}\text { CIIENT: } & \text { Bechrel Nevada } & \text { CLIENT ID: U2BUSW-NOW } \\ \text { PROJECT DD: } & \text { V665 } & \text { DATE SAMPLED: 7/28/99 } \\ \text { PROJECT \#: } & 17777 & \text { NEL SAMPLE DD: L9907287-0S } \\ \text { TEST: } & \text { TCLP-8 Metall } & \\ \text { MATRE: } & \text { Solid } & \end{array}$

\begin{tabular}{|c|c|c|c|c|c|c|c|}
\hline PARAMILIR & $\begin{array}{c}\text { ResULT } \\
\text { mell }\end{array}$ & $\begin{array}{l}\text { REPORIMYG } \\
\text { IMMII }\end{array}$ & D. F. & METEOD & $\begin{array}{c}\text { TCLPSTLC } \\
\text { EXTRACIION } \\
\text { DATE } \\
\end{array}$ & DIGRSTIX & ANAI YZXD \\
\hline Arsenic & $\mathrm{ND}$ & $0.1 \mathrm{me} / \mathrm{L}$ & 1 & EPA 6010 & $8 / 199$ & $8 / 2 / 99$ & $8 / 2 / 99$ \\
\hline Brivium & ND & 1. $m e \sqrt{2}$ & 1 & EPA 6010 & $8 / 1 / 99$ & $8 / 2 / 99$ & $8 / 2 / 99$ \\
\hline Cachriurn & ND & $0.01 \mathrm{med}$ & 1 & EPA 6010 & $8 / 1 / 99$ & $8 / 2 / 99$ & $8 / 2 / 99$ \\
\hline Cbromium & ND & $0.01 \mathrm{~m} / \Omega$ & 1 & EPA 6010 & $8 / 1 / 99$ & $8 / 2 / 99$ & $8 / 2 / 99$ \\
\hline Lead & ND & $0.05 \mathrm{me} / \mathrm{L}$ & 1 & EPA dOI0 & $8 / 1 / 99$ & $8 / 2 / 99$ & $8 / 299$ \\
\hline Mreary & ND & $0.002 \mathrm{men}$ & 10 & EPA $7470 A$ & $8 / 1 / 99$ & $8 / 2 / 99$ & $8 / 2 / 99$ \\
\hline Solenimen & ND & $0.1 \mathrm{mg} / \mathrm{L}$ & 1 & EPA do10 & $8 / 1 / 99$ & $8 / 2 / 99$ & $8 / 2 / 99$ \\
\hline Silver & ND & $0.02 \mathrm{mg} / 2$ & 1 & EPA 6010 & $8 / 1 / 99$ & $8 / 2 / 99$ & $8 / 2 / 99$ \\
\hline
\end{tabular}

D.F. - Dilution Pactor VD - Not Detected

This report shall not be reproduced except in full, without the written approval of the laboratory. 


$\begin{array}{lll}\text { CLIENT: } & \text { Bechtel Nevada } & \text { CLENT ID: } \\ \text { PROJECT D: } & \text { V665 } & \text { U2250SW-S6I } \\ \text { PROJECT \#: } & 17777 & \text { DATE SAMPLED: 7/28/99 } \\ \text { TEST: } & \text { TCLP-8 Metals } & \text { NEL SAMPLE D: L9907287-06 } \\ \text { MATRDX: } & \text { Solid } & \end{array}$

\begin{tabular}{|c|c|c|c|c|c|c|c|}
\hline PARAMLTMR & $\begin{array}{c}\text { RESULT } \\
\text { mel } \\
\end{array}$ & $\begin{array}{l}\text { REPORTING } \\
\text { LMMT } \\
\end{array}$ & D. F. & MMTiOD & $\begin{array}{c}\text { TCLPSTLC } \\
\text { ExTRACTION } \\
\text { DATE }\end{array}$ & DIGXSTND & ANUIYZAND \\
\hline $\begin{array}{l}\text { Arewic } \\
\text { Berrium }\end{array}$ & $\begin{array}{l}\text { ND } \\
\text { ND }\end{array}$ & $\begin{array}{l}0.1 \mathrm{mel} \\
1 . \mathrm{mel}\end{array}$ & 1 & EPA 6010 & $8 / 1 / 99$ & $8 / 2 / 99$ & $8 / 2 / 99$ \\
\hline Codmiven & $\begin{array}{l}\text { ND } \\
\text { ND }\end{array}$ & $0.01 \mathrm{mg} / \mathrm{L}$ & 1 & $\begin{array}{l}\text { EPA } 6010 \\
\text { EPA } 6010\end{array}$ & $8 / 1 / 99$ & $8 / 2 / 99$ & $8 / 2 / 99$ \\
\hline Chroming & ND & $0.01 \mathrm{mg} / \mathrm{L}$ & 1 & $\begin{array}{l}\text { EPA } 6010 \\
\text { EPA } 6010\end{array}$ & 8/1/99 & $8 / 2 / 99$ & $8 / 2 / 99$ \\
\hline Lead & ND & $0.05 \mathrm{mel}$ & 1 & $\begin{array}{l}\text { EPA 6010 } \\
\text { EPA } 6010\end{array}$ & $8 / 1 / 99$ & $8 / 2 / 99$ & $8 / 2 / 99$ \\
\hline Mereary & ND & $0.002 \mathrm{~mol}$ & 10 & $\begin{array}{l}\text { EPA } 6010 \\
\text { EPA 7470A }\end{array}$ & 8/1/99 & $8 / 2 / 99$ & $8 / 2 / 99$ \\
\hline Seleniurs & ND & $0.1 \mathrm{me} / \mathrm{L}$ & 1 & $\begin{array}{l}\text { EPA 7470A } \\
\text { EPA } 6010\end{array}$ & $8 / 1 / 99$ & $8 / 2 / 99$ & $8 / 2 / 99$ \\
\hline Silver & ND & $0.02 \sin \pi$ & 1 & $\begin{array}{l}\text { EPA } 6010 \\
\text { EPA } 6010\end{array}$ & $8 / 1 / 99$ & $8 / 2 / 99$ & $8 / 2 / 99$ \\
\hline
\end{tabular}

D.P. - Dilution Facior

ND - Nor Derceclod

This report shall not be reproduced except in full, without the written approval of the laboratory. 


\begin{tabular}{|c|c|c|c|c|c|c|c|}
\hline $\begin{array}{l}\text { CLIENT: } \\
\text { PROJECT D: } \\
\text { PROJECT \#: } \\
\text { TEST: } \\
\text { MATRD: }\end{array}$ & $\begin{array}{l}\text { Bechidel Nevada } \\
\text { V } 665 \\
17777 \\
\text { TCLP-8 Meonts } \\
\text { Solid }\end{array}$ & & & $\begin{array}{l}\text { CLIENT II } \\
\text { DATE SAN } \\
\text { NEI SAMI }\end{array}$ & $\begin{array}{l}\text { U280ST } \\
\text { TPLED: 7/28/99 } \\
\text { PLE DD: L990728 }\end{array}$ & $\begin{array}{l}-50 W \\
7-07\end{array}$ & \\
\hline PARAMITLR & $\begin{array}{c}\text { RESULT } \\
\text { meL }\end{array}$ & $\begin{array}{c}\text { REPORTING } \\
\text { LIMTI } \\
\end{array}$ & D. $\mathbf{E}$. & METEOD & $\begin{array}{c}\text { TCLPISTLC } \\
\text { EXIRACTION } \\
\text { DATI } \\
\end{array}$ & DIGXSTIED & ANALYZAX \\
\hline Aremic & ND & $0.1 \mathrm{me} / \mathrm{L}$ & 1 & EPA 6010 & $8 / 1 / 99$ & $8 / 2 / 99$ & 8/2/99 \\
\hline Batiun & ND & 1. $m e x$ & 1 & EPA $\$ 010$ & $8 / 1 / 99$ & $8 / 2 / 99$ & $8 / 2 / 99$ \\
\hline Codmium & ND & $0.01 \mathrm{me} / \mathrm{L}$ & 1 & EPA ф010 & 8/1/99 & $8 / 2 / 99$ & $8 / 2 / 99$ \\
\hline Chrominem & ND & $0.01 \mathrm{mg} / \mathrm{L}$ & 1 & EPA 9010 & $8 / 1 / 99$ & $8 / 2 / 99$ & $8 / 2 / 99$ \\
\hline Loed & ND & $0.05 \mathrm{mel}$ & 1 & EPA 6010 & $8 / 1 / 99$ & $8 / 2 / 99^{\circ}$ & $8 / 2 / 99$ \\
\hline Meraury & ND & $0.002 \operatorname{mog} 2$ & 10 & EPA 7470A & $8 / 1 / 99$ & $8 / 2 / 99$ & $8 / 2 / 99$ \\
\hline Selavium & ND & $0.1 \mathrm{mg} / \mathrm{L}$ & 1 & EPA 6010 & $8 / 1 / 99$ & $8 / 2 / 99$ & $8 / 2 / 99$ \\
\hline Silver & ND & $0.02 \mathrm{mg} / \mathrm{L}$ & 1 & EPA 6010 & $8 / 1 / 99$ & $8 / 2 / 99$ & $8 / 2 / 99$ \\
\hline
\end{tabular}

D.F. - Dilucion Factor

ND - Not Detected

This reporn shall not be reproduced except in full. without the written approval of the laborator. 


$\begin{array}{lll}\text { CLIENT: } & \text { Bcchrel Nevada } & \text { CLIEAT D: } \\ \text { PROJECT DD: } & \text { V665 } & \text { DATUSW - LON } \\ \text { PROJECT \#: } & 17777 & \text { NAT SAMPLED: 7/28/99 } \\ \text { TEST: } & \text { TCLP-8 Metals } & \text { NAMPLE D: L9907287-08 } \\ \text { MATRJX: } & \text { Solid } & \end{array}$

\begin{tabular}{|c|c|c|c|c|c|c|c|}
\hline PARAMITIOR & $\begin{array}{c}\text { RESULT } \\
\text { mell } \\
\end{array}$ & $\begin{array}{c}\text { REPORIIIG } \\
\text { LMMT } \\
\end{array}$ & D. $\mathbf{E}$. & METIOD & $\begin{array}{c}\text { TCLPSTLC } \\
\text { DXTRACIION } \\
\text { DATI } \\
\end{array}$ & DIGSSTID & ANATMZan \\
\hline Arsanic & ND & $0.1 \mathrm{mg} / \mathrm{L}$ & 1 & EPA 6010 & $8 / 1 / 99$ & $8 / 2 / 99$ & $8 / 2 / 99$ \\
\hline Bariugen & ND & 1. $m e /$ & 1 & EPA 6Plo & $8 / 1 / 99$ & $8 / 2 / 99$ & $8 / 2 / 99$ \\
\hline Cadrovium & ND & $0.01 \mathrm{mg} / \mathrm{L}$ & 1 & EPA 6DI0 & $8 / 1 / 99$ & $8 / 2 / 99$ & $8 / 2 / 99$ \\
\hline Cleromium & ND & $0.01 \mathrm{mg} /$ & 1 & EPA 6D10 & $8 / 1 / 99$ & $8 / 2 / 99$ & $8 / 2 / 99$ \\
\hline Iead & ND & $0.05 \mathrm{mgl}$ & 1 & EPA 6010 & $8 / 1 / 99$ & $8 / 2 / 99$ & $8 / 2 / 99$ \\
\hline Merewry & ND & $0.002 \mathrm{~mol}$ & 10 & EPA 7470A & $8 / 1 / 99$ & $8 / 2 / 99$ & $8 / 2 / 99$ \\
\hline Soleniam & ND & $0.1 \mathrm{~mol}$ & 1 & EPA 6010 & $8 / 1 / 99$ & $8 / 2 / 99$ & $8 / 2 / 99$ \\
\hline Silvar & ND & $0.02 \mathrm{me} /$ & 1 & EPA 6010 & $8 / 1 / 99$ & $8 / 2 / 99$ & $8 / 2 / 99$ \\
\hline
\end{tabular}

\section{D.F. - Dihution Fuetor \\ ND - Not Detected}

This report shall not be reproduced except in full, without the wrinen apptoval of the laboratory. 


\section{NEL LABORATORIES}

$\begin{array}{lll}\text { CLIENT: } & \text { Bechwed Nevada } & \text { CLIENT D: } \\ \text { PROJECT D: } & \text { V665 } & \text { U2BUSW - 265 } \\ \text { PROJECT \#: } & 17777 & \text { DATE SAMPLED: 7/28/99 } \\ & \text { NEL SAMPLE ID: L9907287-09 } \\ \text { TEST: } & \text { TCLP-8 Metals } & \\ \text { MATRIX: } & \text { Solid } & \end{array}$

\begin{tabular}{|c|c|c|c|c|c|c|c|}
\hline PARAMITTXR & $\begin{array}{c}\text { RESULT } \\
\text { meL } \\
\end{array}$ & $\begin{array}{c}\text { REPORTING } \\
\text { LDMI } \\
\end{array}$ & D.F. & METEOD & $\begin{array}{l}\text { TCLPSTLC } \\
\text { EXIRACTION } \\
\text { DATE } \\
\end{array}$ & DLGESTIED & ANAX YZZOD \\
\hline Arsenic & ND & $0.1 \mathrm{me} / \mathrm{L}$ & 1 & EPA 6010 & $8 / 1 / 99$ & $8 / 2 / 99$ & $8 / 2 / 99$ \\
\hline Barium & $\mathbf{N D}$ & 1. $m / 2$ & 1 & EPA 6010 & $8 / 1 / 99$ & $8 / 2 / 99$ & $8 / 2 / 99$ \\
\hline Cadreinur & $\mathbf{N D}$ & $0.01 \mathrm{mg} /$ & 1 & EPA 6010 & $8 / 1 / 99$ & $8 / 2 / 99$ & $8 / 2 / 99$ \\
\hline Chromium & ND & $0.01 \mathrm{mg} \Omega$ & 1 & EPA 6D10 & $8 / 1 / 99$ & $8 / 2 / 99$ & $8 / 2 / 99$ \\
\hline Lead & ND & $0.05 \mathrm{mel}$ & 1 & EPA 6DIO & $8 / 1 / 99$ & $8 / 2 / 99$ & $8 / 2 / 99$ \\
\hline Mereury & ND & $0.002 \mathrm{mog} /$ & 10 & EPA 7470A & $8 / 1 / 99$ & $8 / 2 / 99$ & $8 / 2 / 99$ \\
\hline Solexiven & ND & $0.1 \mathrm{mg} / \mathrm{L}$ & 1 & EPA 6010 & $8 / 1 / 99$ & $8 / 2 / 99$ & $8 / 2 / 99$ \\
\hline Silver. & ND & $0.02 \mathrm{~m} / \mathrm{L}$ & 1 & EPA 6010 & $8 / 1 / 99$ & $8 / 2 / 99$ & $8 / 2 / 99$ \\
\hline
\end{tabular}

D.F. - Diztation Factor

ND - Not Detected

This report shall not be reproduced except in full, without the written approval of the laboratory. 


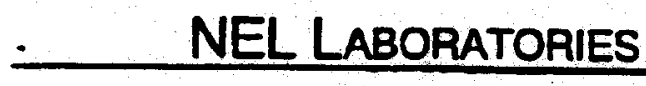

CIIENT: Beched Nereda

PROJECT ID: V665

CLIEAT ID: UZEUSW - WON

PROJECT \#: $\quad 17777$

DATE SAMPLED: 7/28/99

TEST: TCLP-8 Metrls

MATRIX: Solid

\begin{tabular}{|c|c|c|c|c|c|c|c|}
\hline PARAMTIXB & $\begin{array}{c}\text { RESURT } \\
\text { me } \Lambda \\
\end{array}$ & $\begin{array}{c}\text { REPORTING } \\
\text { IMII } \\
\end{array}$ & D.F. & MITHOD & $\begin{array}{c}\text { TCLPSTLC } \\
\text { EXTRACTION } \\
\text { DATE }\end{array}$ & DIGXSTMD & ANALYZADD \\
\hline Arnonic & ND & $0.1 \mathrm{mel}$ & 1 & EPA 6p10 & $8 / 1 / 99$ & $8 / 2 / 99$ & $8 / 2 / 99$ \\
\hline Borrium & ND & 1. mell & 1 & EPA 6010 & $8 / 1 / 99$ & $8 / 2 / 99$ & $8 / 2 / 99$ \\
\hline Cuchoniura & ND & $0.01 \mathrm{mg}$ & 1 & EPA 6010 & $8 / 1 / 99$ & $8 / 2 / 99$ & $8 / 2 / 99$ \\
\hline Chrominn & ND & $0.01 \mathrm{mg} /$ & 1 & EPA 6010 & $8 / 1 / 99$ & $8 / 2 / 99$ & $8 / 2 / 99$ \\
\hline Fend & ND & $0.05 \mathrm{mg} \pi$ & 1 & EPA 6010 & $8 / 1 / 99$ & 8/2/99 & $8 / 2 / 99$ \\
\hline Mereury & ND & $0.002 \mathrm{mg} /$ & 10 & EPA 7470A & $8 / 1 / 99$ & $8 / 2 / 99$ & $8 / 2 / 99$ \\
\hline Selenivm & ND & $0.1 \mathrm{mg} /$ & 1 & EPA 6010 & $8 / 1 / 99$ & $8 / 2 / 99$ & $8 / 2 / 99$ \\
\hline Silver & ND & $0.02 \mathrm{mg} / \mathrm{L}$ & 1 & EPA 6010 & $8 / 1 / 99$ & $8 / 2 / 99$ & $8 / 2 / 99$ \\
\hline
\end{tabular}

D.F. - Dihution Factor

ND - Not Detected

This report shall not be roproduced except in full, without the wrizen apppoval of the laboratory. 


\begin{tabular}{|c|c|c|}
\hline $\begin{array}{l}\text { CIIENT: } \\
\text { PROJECT D: } \\
\text { PROJECT \#: }\end{array}$ & $\begin{array}{l}\text { Bochrel Nevada } \\
\text { V665 } \\
17777\end{array}$ & $\begin{array}{ll}\text { CLENT D: } & \text { O2BUSW - W6S } \\
\text { DATE SAMPLED: 7/28/99 } \\
\text { NEI SAMPLE DD: } 29907287-11\end{array}$ \\
\hline $\begin{array}{l}\text { TEST: } \\
\text { MATRIX: }\end{array}$ & $\begin{array}{l}\text { TCLP-8 Mecels } \\
\text { Solid }\end{array}$ & \\
\hline
\end{tabular}

\begin{tabular}{|c|c|c|c|c|c|c|c|}
\hline PARAMTETSR & $\begin{array}{c}\text { RSSULT } \\
\text { mgll } \\
\end{array}$ & $\begin{array}{l}\text { REPORTING } \\
\text { LMMT } \\
\end{array}$ & D. F. & METAOD & $\begin{array}{c}\text { TCLPSTIC } \\
\text { EXIRACTION } \\
\text { DATL } \\
\end{array}$ & DIGESTIBD & ANAIYZADD \\
\hline Arsomic & ND & $0.1 m g / L$ & 1 & EPA 6 P10 & $8 / 1 / 99$ & $8 / 2 / 99$ & $8 / 2 / 99$ \\
\hline Barium & ND & 1. $m e / 1$ & 1 & EPA 6p10 & $8 / 1 / 99$ & $8 / 2 / 99$ & $8 / 2 / 99$ \\
\hline Cadmiven & ND & $0.01 \mathrm{mg} 2$ & 1 & EPA 6010 & $8 / 1 / 99$ & $8 / 2 / 99$ & $8 / 2 / 99$ \\
\hline Ahrowiven & ND & $0.01 \mathrm{mg} / \mathrm{L}$ & 1 & EPA 6010 & $8 / 1 / 99$ & $8 / 2 / 99$ & $8 / 2 / 99$ \\
\hline Joad & ND & $0.05 \mathrm{me} / \mathrm{L}$ & 1 & EPA 6010 & $8 / 1 / 99$ & $8 / 2 / 99$ & $8 / 2 / 99$ \\
\hline Mexcory & ND & $0.002 \mathrm{mp} / \mathrm{L}$ & 10 & EPA 7470A & $8 / 1 / 99$ & $8 / 2 / 99$ & $8 / 2 / 99$ \\
\hline Selenium & ND & $0.1 \mathrm{mg} / \mathrm{L}$ & 1 & EPA G10 & $8 / 1 / 99$ & $8 / 2 / 99$ & $8 / 2 / 99$ \\
\hline Silver & ND & $0.02 \mathrm{mg} /$ & 1 & EPA op10 & $8 / 1 / 99$ & $8 / 2 / 99$ & $8 / 2 / 99$ \\
\hline
\end{tabular}

D.F. - Dilution Pactor

ND - Nor Detected

This report shall not be reproduced except in full, without the written approval of the laborator: 


\begin{tabular}{|c|c|c|c|}
\hline $\begin{array}{l}\text { CLIENT: } \\
\text { PROJECT D: } \\
\text { PROJECT \#: }\end{array}$ & $\begin{array}{l}\text { Bectrel Nevada } \\
\text { Y } 665 \\
17777\end{array}$ & $\begin{array}{l}\text { CLIEITI D: } \\
\text { DATA SAMPLED: } \\
\text { NEL SAMPLE D: }\end{array}$ & $\begin{array}{l}\text { U2BU-7209918 } \\
7 / 28 / 99 \\
\text { L9907287-12 }\end{array}$ \\
\hline $\begin{array}{l}\text { TEST: } \\
\text { MATRIX: }\end{array}$ & $\begin{array}{l}\text { TCLP-8 Metals } \\
\text { Agneous }\end{array}$ & & \\
\hline
\end{tabular}

\begin{tabular}{|c|c|c|c|c|c|c|c|}
\hline PARAMITIRR & $\begin{array}{c}\text { RxSULT } \\
\text { mel } \\
\end{array}$ & $\begin{array}{l}\text { DEPORIING } \\
\text { LMMI } \\
\end{array}$ & D.E. & NETEOD & $\begin{array}{l}\text { TCLPAILC } \\
\text { DETRACIION } \\
\text { DATI } \\
\end{array}$ & DICXSTMD & ANALYZATD \\
\hline Artenic & ND & $0.1 \mathrm{mg} /$ & 1 & EPA 6010 & $\mathrm{NA}$ & $8 / 2 / 99$ & $8 / 2 / 99$ \\
\hline Bariven & ND & 1. $m e x$ & 1 & EPA 0010 & NA & $8 / 2 / 99$ & $8 / 2 / 99$ \\
\hline Caxdminen & ND & $0.01 \mathrm{mg} / L$ & 1 & EPA 6010 & NA & $8 / 2 / 99$ & $8 / 2 / 99$ \\
\hline Chromines & ND & $0.01 \mathrm{mgl}$ & 1 & EPA 010 & NA & $8 / 2 / 99$ & $8 / 2 / 99$ \\
\hline Load & ND & $0.05 \mathrm{mel}$ & 1 & EPA OPIO & NA & $8 / 2 / 99$ & $8 / 2 / 99$ \\
\hline Merany & 0.014 & $0.002 \mathrm{mel}$ & 10 & EPA 7470A & NA & $8 / 2 / 99$ & $8 / 2 / 99$ \\
\hline Solanirm & $\mathbf{N D}$ & $0.1 \mathrm{mel}$ & 1 & EPA & NA & $8 / 2 / 99$ & $8 / 2 / 99$ \\
\hline Silver & ND & $0.02 \mathrm{me} / \mathrm{L}$ & 1 & EPA 6010 & NA & $8 / 2 / 99$ & $8 / 2 / 99$ \\
\hline
\end{tabular}

D.F. - Dihution Factor

ND - Not Detected

This repon shall not be reproduced except in full, withous the wrinen app oval of the laboratory. 


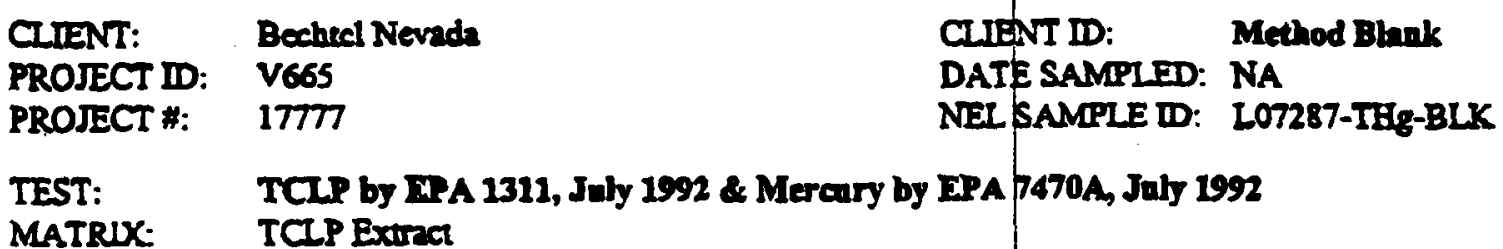

MATRUX TCLP Exusct

\begin{tabular}{|c|c|c|c|c|c|c|c|}
\hline \multirow[b]{2}{*}{ PARAMIIXR } & \multicolumn{3}{|c|}{ RMPORTING } & \multicolumn{3}{|c|}{$\begin{array}{l}\text { TCLPSTLC } \\
\text { EXTRACTION }\end{array}$} & \\
\hline & RXSULI & LIMIT & D. F. & MEthOD & DATE & DIGESTED & ANAI YZADD \\
\hline Merewy & ND & $0.002 \mathrm{mel}$ & 10 & EPA $7470 A$ & $8 / 1 / 99$ & $8 / 2 / 99$ & $8 / 2 / 99$ \\
\hline
\end{tabular}

D.F. - Dimrion Factor

ND - Not Derected

This report shall not be reproduced except in full, without the written approval of the laboratory. 


\begin{tabular}{|c|c|c|c|}
\hline $\begin{array}{l}\text { CIENT: } \\
\text { PROJECT D: } \\
\text { PROJECT \#: }\end{array}$ & $\begin{array}{l}\text { Bechtel Nevada } \\
\text { V665 } \\
17777\end{array}$ & $\begin{array}{l}\text { CLENT D: } \\
\text { DATE SAMPLED: } \\
\text { NEL SAMPLEID: }\end{array}$ & $\begin{array}{l}\text { Method Btark } \\
\text { NA } \\
\text { L07287T-BLK }\end{array}$ \\
\hline MATRXX: & TCP Extre & & \\
\hline
\end{tabular}

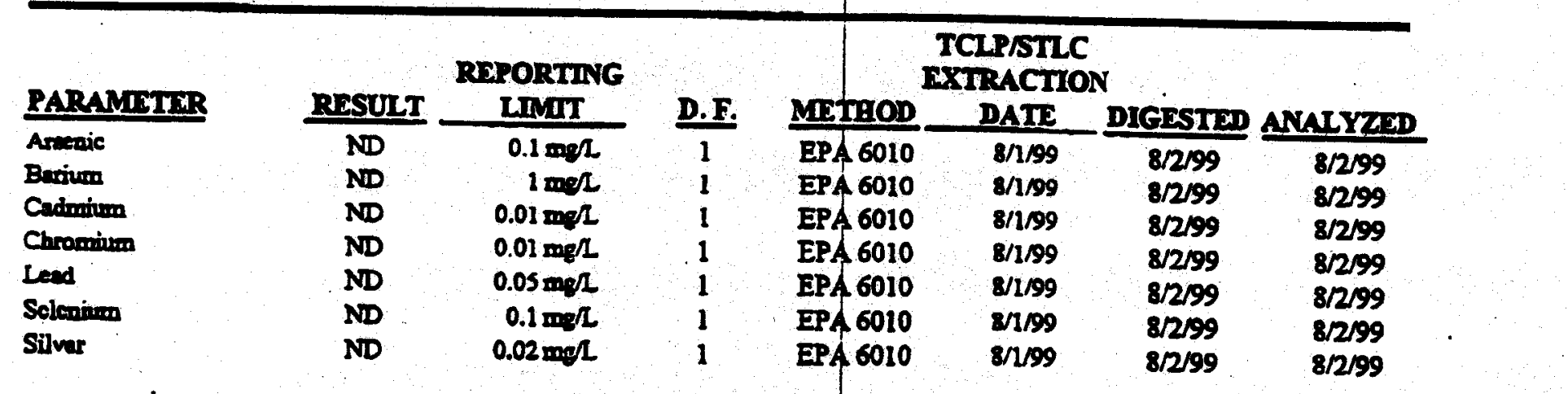

D.F. - Dihution Factor

ND - Not Detected

This reporn shall not be reproduced except in full, without the written opproval of the laboratory. 


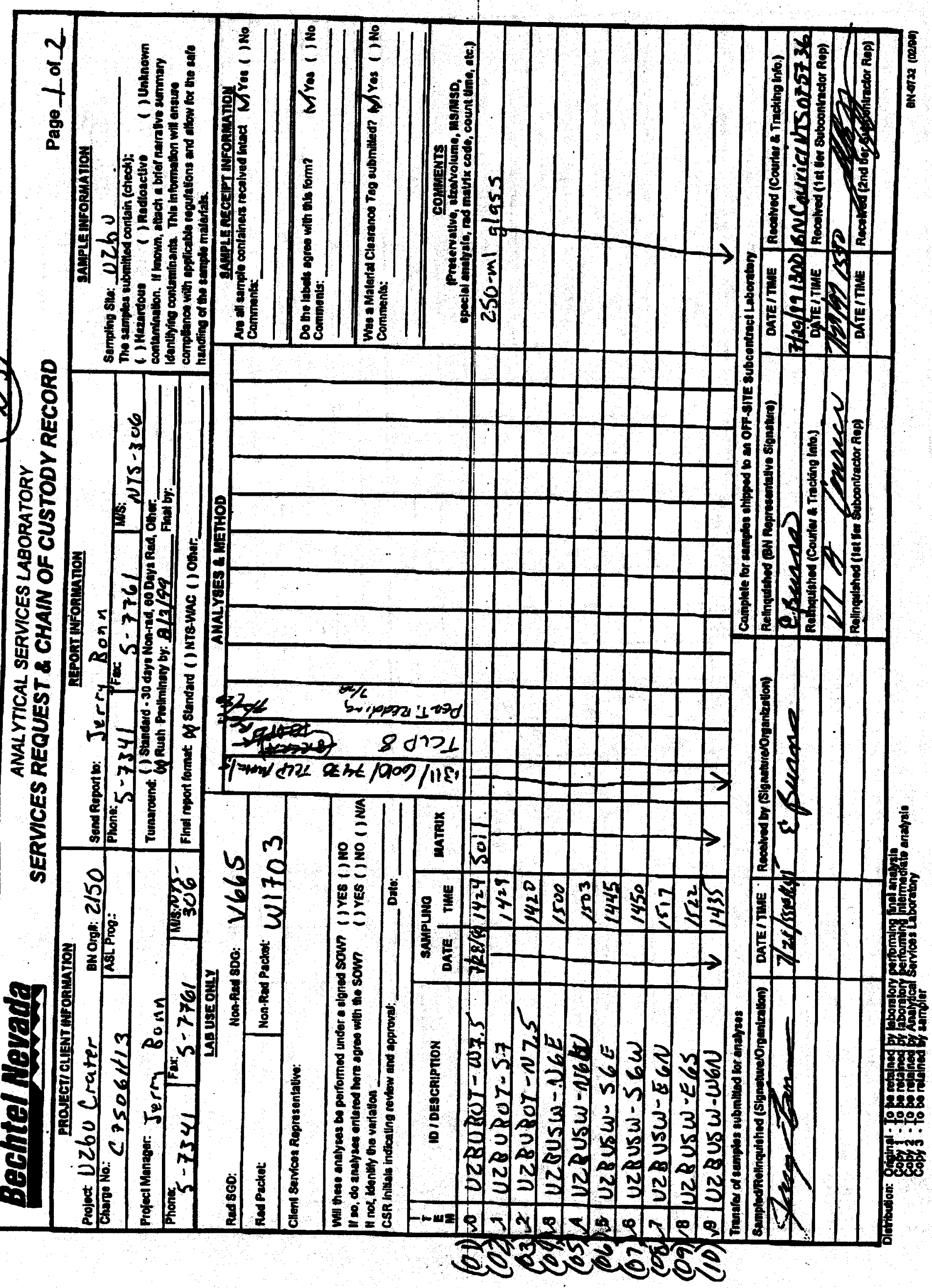


APPENDIX D

\section{PHOTOGRAPHS OF CLOSURE ACTIVITIES}


Cosure Report-CAUNo. 109

U-2bu Substidene Crater

Section: APEDDDX O

Revigion: 0

Date: $1 / 3 / 99$
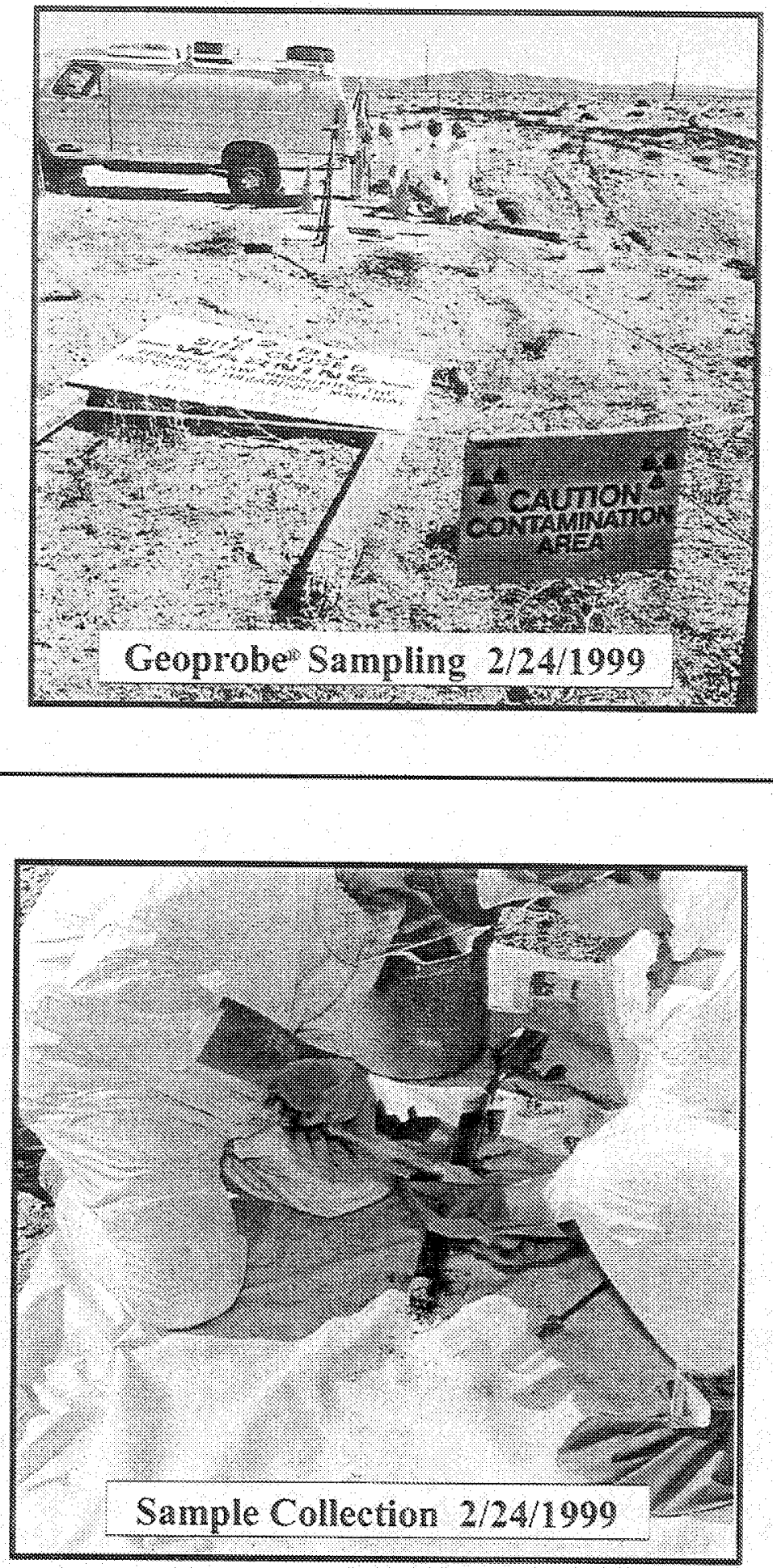

APPENDIX D

PLATE

D-1 


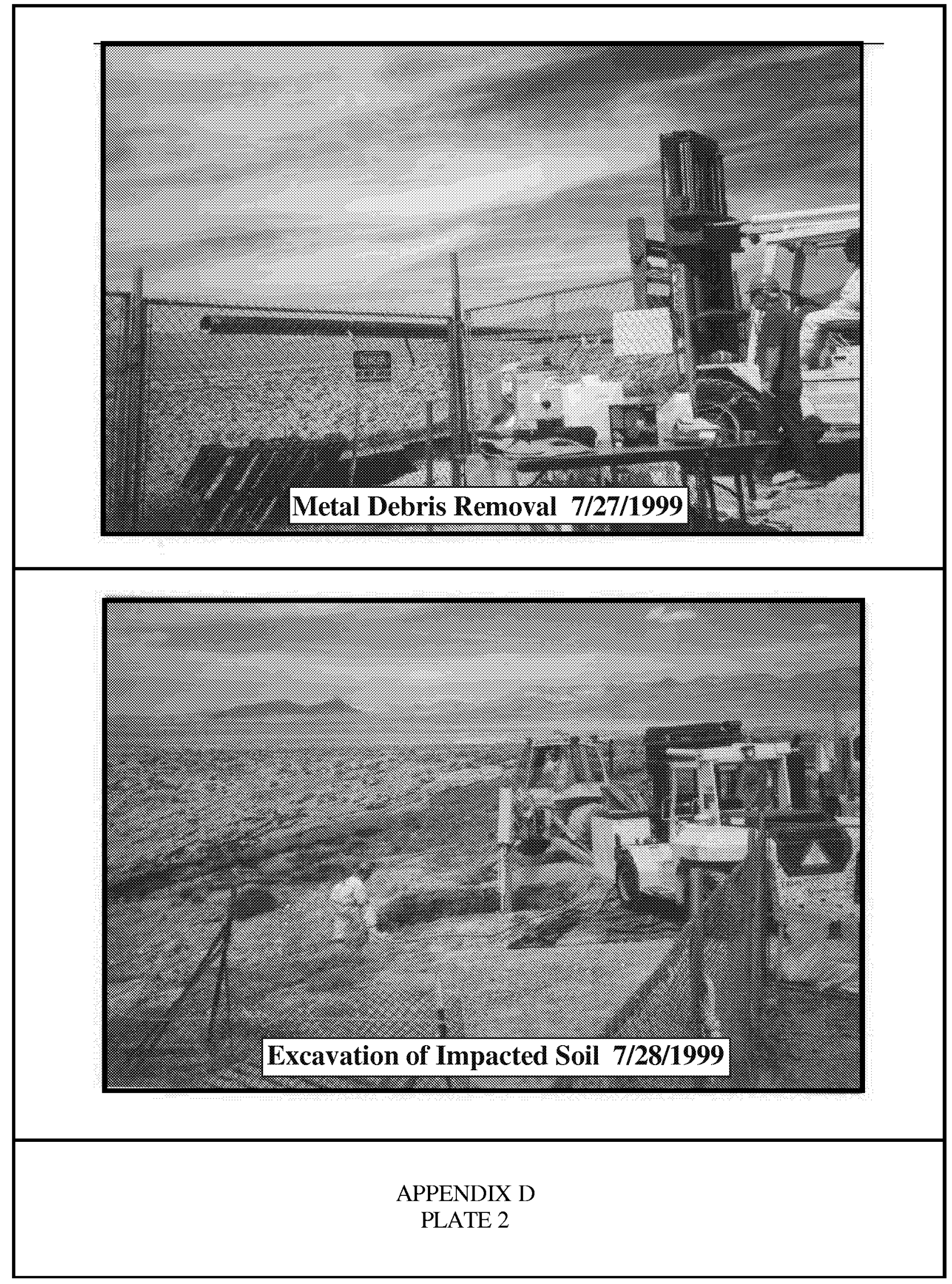

D-2 


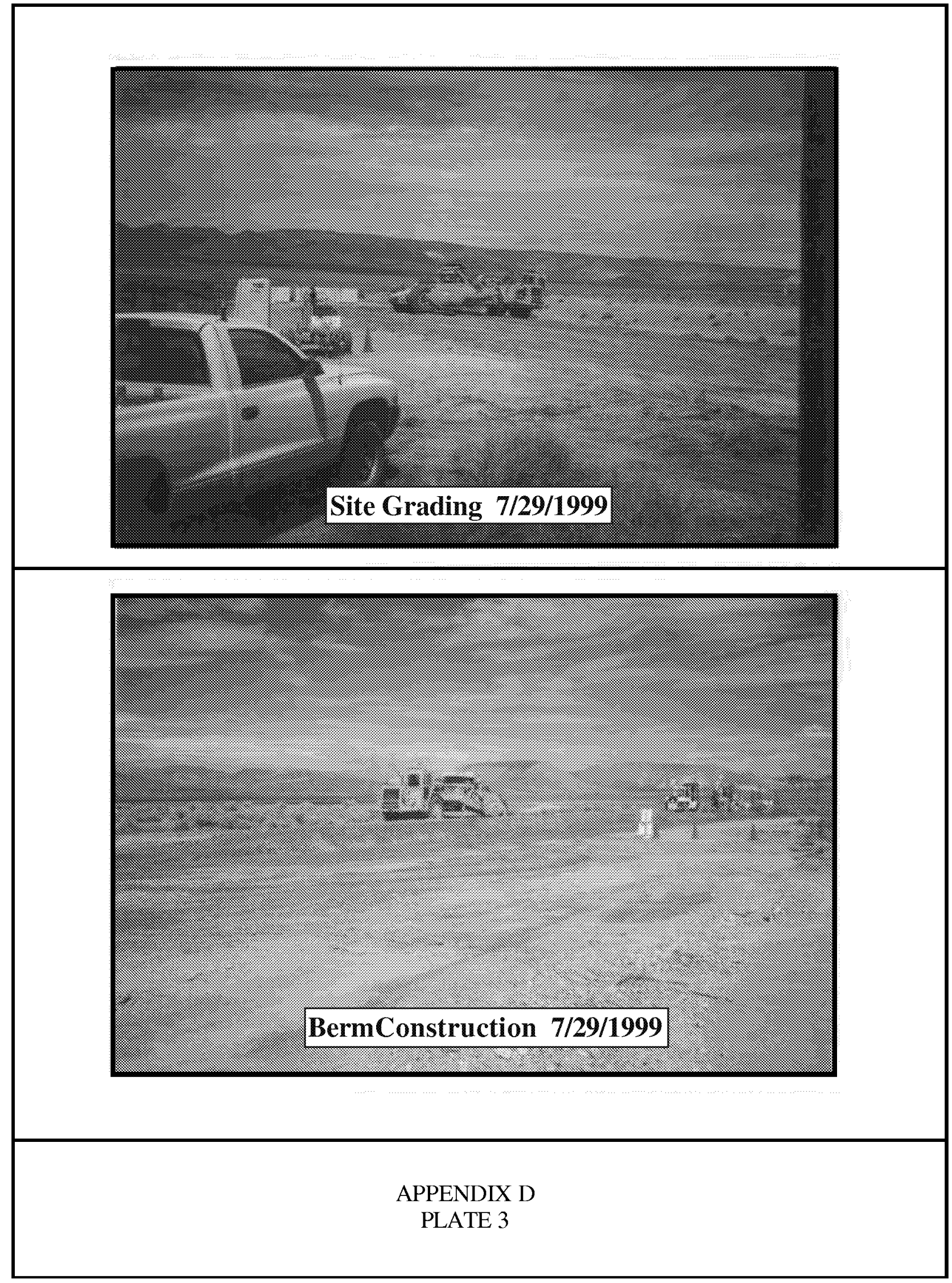

D-3 
ClosureReport-CAUNo.109

U-2buSubsidenceCrater

Section:APPENDIXD

Revision:0

Date:9/30/99
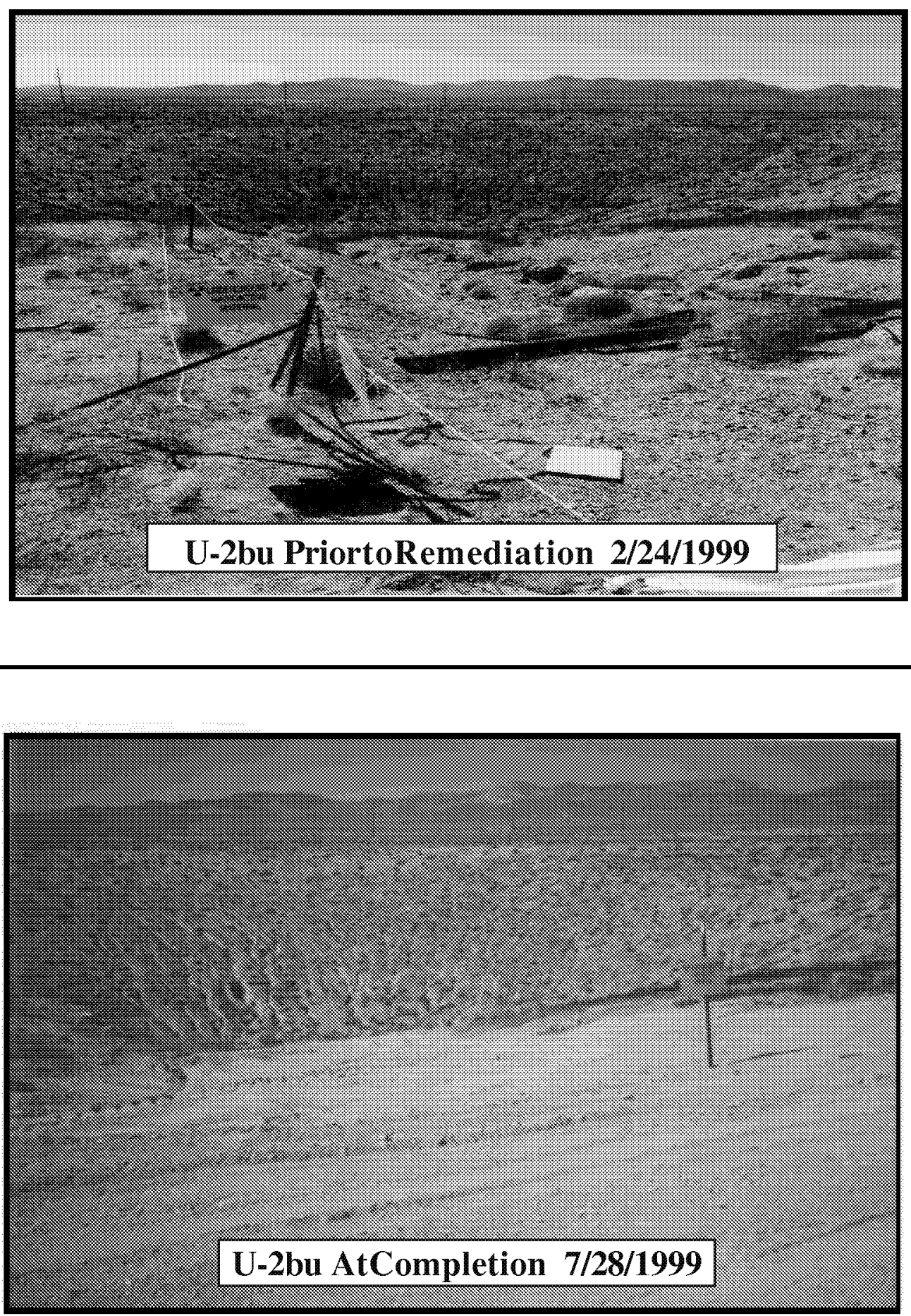

APPENDIX D

PLATE 4

D-4 
THIS PAGE INTENTIONALLY LEFT BLANK 


\section{DISTRIBUTION LIST}


THIS PAGE INTENTIONALLY LEFT BLANK 


\section{DISTRIBUTION LIST}

*Provide copy of initial distribution of Revision 0; remainder of list gets Revision 0 if approved without changes. The entire list receives Revision 1, if issued.

\section{Nevada Department of Environmental Protection}

Paul Liebendorfer

Bureau of Federal Facilities

Division of Environmental Protection

333 W. Nye Lane, Room 13B

Carson City, NV 89706-0866

Mike McKinnon

Bureau of Federal Facilities

Division of Environmental Protection

555 E. Washington, Suite 4300

Las Vegas, NV 89010-1043
2 (Controlled)*

1 (Controlled)*

\section{U.S. Department of Energy}

Janet Appenzeller-Wing

1 (Uncontrolled)*

Environmental Restoration Division

U.S. Department of Energy, Nevada Operations Office

P.O. Box 98518 M/S 505

Las Vegas, NV 89193-8518

Sabine Curtis

1 (Uncontrolled)*

Environmental Restoration Division

U.S. Department of Energy, Nevada Operations Office

P.O. Box $98518 \mathrm{M} / \mathrm{S} 505$

Las Vegas, NV 89193-8518

Sabrina Lawrence

1 (Controlled)*

Environmental Restoration Division

U.S. Department of Energy, Nevada Operations Office

P.O. Box $98518 \mathrm{M} / \mathrm{S} 505$

Las Vegas, NV 89193-8518

DOE Public Reading Room

1 (Controlled)

P.O. Box $98521 \mathrm{M} / \mathrm{S}$ NLV040

Las Vegas, NV 89193-8521 


\section{DISTRIBUTION LIST (Continued)}

DOE/Nevada Operations Office

1 (Uncontrolled)

Technical Information Resource Center

P.O. Box $98521 \mathrm{M} / \mathrm{S} 505$

Las Vegas, NV 89193-8521

U.S. Department of Energy

2 (Uncontrolled)

Office of Scientific and Technical Information

175 Oak Ridge Turnpike

P.O. Box 62

Oak Ridge, TN 37831-0062

\section{Bechtel Nevada}

Correspondence Control

1 (Uncontrolled)*

Bechtel Nevada

P.O. Box $98521 \mathrm{M} / \mathrm{S}$ NLV008

Las Vegas, NV 89193-8521

Environmental Management Library

1 (Uncontrolled)*

Bechtel Nevada

P.O. Box 98521 M/S NLV080

Las Vegas, NV 89193-8521

Jerry Bonn

1 (Uncontrolled)*

Bechtel Nevada

P.O. Box 98521 M/S NTS306

Las Vegas, NV 89193-8521

Janet Cowley

1 (Uncontrolled)

Bechtel Nevada

P.O. Box $98521 \mathrm{M} / \mathrm{S}$ NTS110

Las Vegas, NV 89193-8521

David Cowser

1 (Uncontrolled)*

Bechtel Nevada

P.O. Box $98521 \mathrm{M} / \mathrm{S}$ NLV082

Las Vegas, NV 89193-8521

Ann Heidema

1 (Uncontrolled)

Bechtel Nevada

P.O. Box $98521 \mathrm{M} / \mathrm{S}$ NLV022

Las Vegas, NV 89193-8521 


\section{DISTRIBUTION LIST (Continued)}

Wayne Johnson

1 (Uncontrolled)*

Bechtel Nevada

P.O. Box $98521 \mathrm{M} / \mathrm{S}$ NTS306

Las Vegas, NV 89193-8521

Patrick Matthews

1 (Uncontrolled)

Bechtel Nevada

P.O. Box $98521 \mathrm{M} / \mathrm{S}$ NLV180

Las Vegas, NV 89193-8521

Steve Nacht

1 (Uncontrolled)*

Bechtel Nevada

P.O. Box $98521 \mathrm{M} / \mathrm{S}$ NTS306

Las Vegas, NV 89193-8521

Shannon Parsons-DePry

1 (Uncontrolled)*

Bechtel Nevada

P.O. Box 98521 M/S NTS306

Las Vegas, NV 89193-8521

Phil Ralphs

1 (Uncontrolled)

Bechtel Nevada

P.O. Box $98521 \mathrm{M} / \mathrm{S}$ NTS330

Las Vegas, NV 89193-8521

\section{$\underline{\text { IT Corporation }}$}

Brad Jackson

1 (Uncontrolled)*

IT Corporation

P.O. Box 93838

Las Vegas, NV 89193-8521

Rosa Silver

2 (Controlled)

IT Corporation

P.O. Box 93838

Las Vegas, NV 89193-8521 


\section{DISTRIBUTION LIST (Continued)}

\section{PEER Consultants}

Gary Hudak

1 (Uncontrolled)

PEER Consultants

P.O. Box $98521 \mathrm{M} / \mathrm{S}$ NLV082

Las Vegas, NV 89193-8521

Dean Nelson

1 (Uncontrolled)

PEER Consultants

575 Oak Ridge Turnpike

Oak Ridge, TN 37830-7100 
NEVADA DIVISION OF ENVIRONMENTAL PROTECTION DOCUMENT REVIEW SHEET 
THIS PAGE LEFT INTENTIONALLY LEFT BLANK 


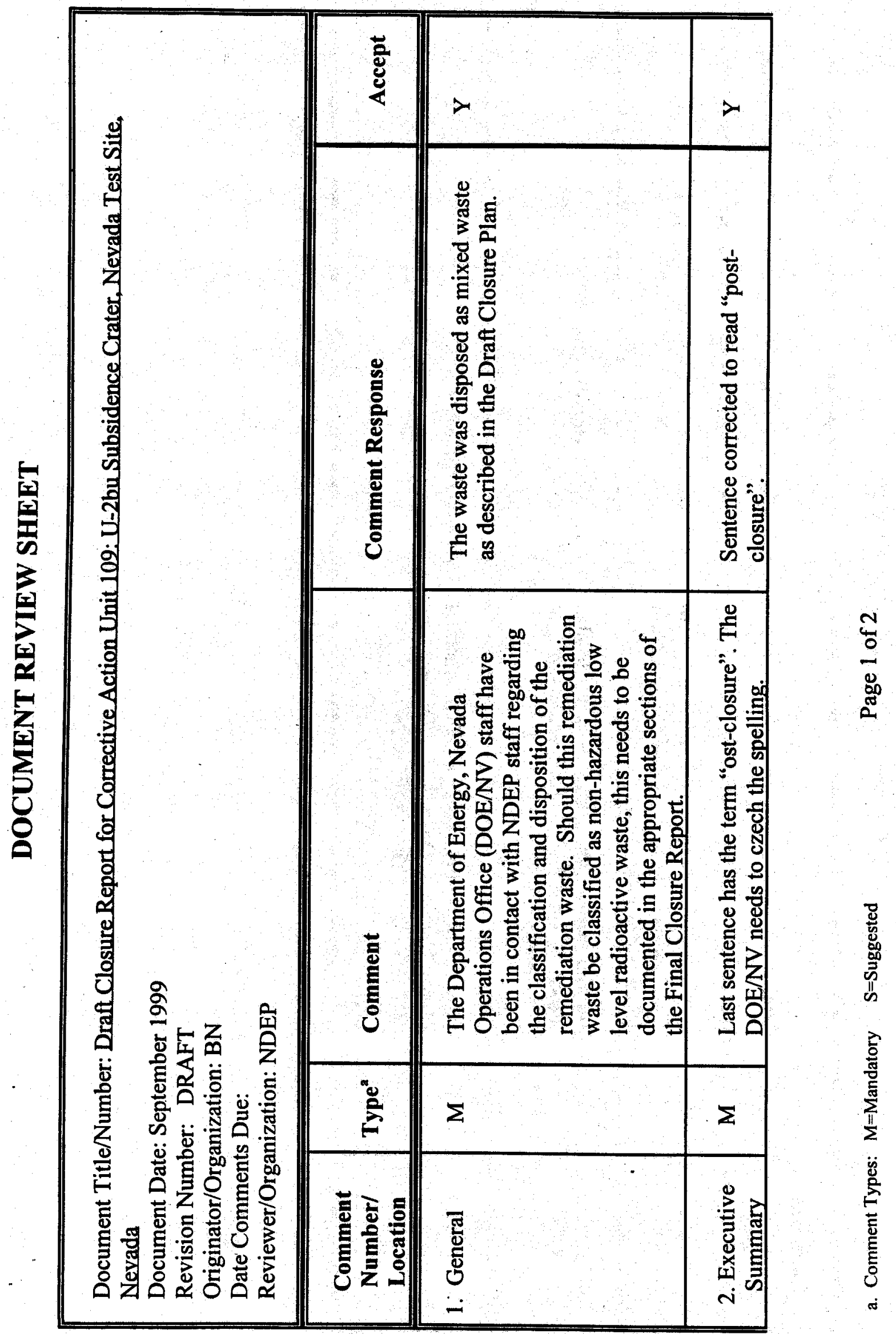




\section{DOCUMENT REVIEW SHEET}

\begin{tabular}{|c|c|l|l|l|}
\hline $\begin{array}{c}\text { Comment } \\
\text { Number/ } \\
\text { Location }\end{array}$ & Type & Comment & Comment Response & Accept \\
\hline $\begin{array}{c}\text { 3. Section } \\
2.1 .6\end{array}$ & $\mathrm{M}$ & $\begin{array}{l}\text { Figure 2 is referenced as showing the berm } \\
\text { construction. NDEP found the berm } \\
\text { information on Figure 4. }\end{array}$ & The reference was changed to Figure 4. & Y \\
\hline $\begin{array}{c}\text { 4. Section } \\
2.1 .8\end{array}$ & $\mathrm{M}$ & $\begin{array}{l}\text { For clarification, the DOE/NV needs to also } \\
\text { cite 40 CFR §270.1(c)(5) in conjunction with } \\
\text { 40 CFR \$264.115. }\end{array}$ & The additional regulation was cited. & Y \\
\hline $\begin{array}{c}\text { 5. Appendix } \\
\text { A }\end{array}$ & $\mathrm{M}$ & $\begin{array}{l}\text { On the Certification by the U.S. Department of } \\
\text { Energy/Nevada Operations Office, the } \\
\text { DOE/NV cites "Title 40 CFR 260-168", the } \\
\text { correct citation is "Title 40 CFR 260-270." }\end{array}$ & The citation was corrected. & Y \\
\hline
\end{tabular}

